ORNL/TM-2000/254

\title{
Life Cycle Analysis for Treatment and Disposal of PCB Waste at Ashtabula and Fernald
}

\author{
Michael I. Morris \\ Katherine L. Yuracko \\ Oak Ridge National Laboratory, Oak Ridge, Tennessee \\ Richard A. Govers \\ The Chamberlain Group, Lynchburg, Virginia
}

\author{
Prepared for \\ Douglas M. Maynor \\ U.S. Department of Energy \\ Ohio Field Office \\ Technology and Waste Minimization Support \\ and \\ J. Kent Hancock \\ U.S. Department of Energy \\ Office of Environmental Management \\ Pollution Prevention Team
}


This report has been reproduced from the best available copy. Reports are available to the public from the following source:

National Technical Information Service

5285 Port Royal Road

Springfield, VA 22161

Telephone: 703-605-6000 (1-800-553-6847)

TDD: 703-487-4639

Fax: 703-605-6900

E-mail: orders@ntis.fedworld.gov

Web site: http://www.ntis.gov/ordering.htm

Reports are available to U.S. Department of Energy (DOE) employees, DOE contractors, Energy Technology Data Exchange (ETDE) representatives, and International Nuclear Information System (INIS) representatives from the following source:

Office of Scientific and Technical Information

P.O. Box 62

Oak Ridge, TN 37831

Telephone: 423-576-8401

Fax: 423-576-5728

E-mail: reports@adonis.osti.gov

Web site: http://www.osti.gov/products/sources.html

Reports produced after January 1, 1996, are generally available via the DOE Information Bridge (http://www.doe.gov/bridge):

Web site http://www.doe.gov/bridge

This report was prepared as an account of work sponsored by an agency of the United States Government. Neither the United States Government nor any agency thereof, nor any of their employees, makes any warranty, express or implied, or assumes any legal liability or responsibility for the accuracy, completeness, or usefulness of any information, apparatus, product, or process disclosed, or represents that its use would not infringe privately owned rights. Reference herein to any specific commercial product, process, or service by trade name, trademark, manufacturer, or otherwise, does not necessarily constitute or imply its endorsement, recommendation, or favoring by the United States Government or any agency thereof. The views and opinions of authors expressed herein do not necessarily state or reflect those of the United States Government or any agency thereof. 
ORNL/TM-2000/254

\title{
Life Cycle Analysis for Treatment and Disposal of PCB Waste at Ashtabula and Fernald
}

\author{
Michael I. Morris \\ Katherine L. Yuracko \\ Oak Ridge National Laboratory, Oak Ridge, Tennessee \\ Richard A. Govers \\ The Chamberlain Group, Lynchburg, Virginia
}

September 2000

\author{
Prepared for \\ Douglas M. Maynor \\ U.S. Department of Energy \\ Ohio Field Office \\ Technology and Waste Minimization Support \\ and \\ J. Kent Hancock \\ U.S. Department of Energy \\ Office of Environmental Management \\ Pollution Prevention Team \\ Prepared by the \\ Center for Life Cycle Analysis \\ Oak Ridge National Laboratory \\ Oak Ridge, Tennessee 37831 \\ managed by \\ UT-Battelle, LLC \\ for the \\ U.S. Department of Energy \\ under contract DE-AC05-00OR22725
}




\section{Contents}

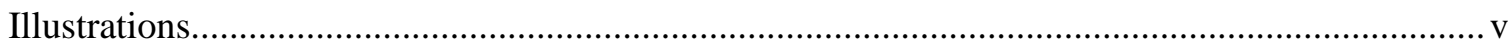

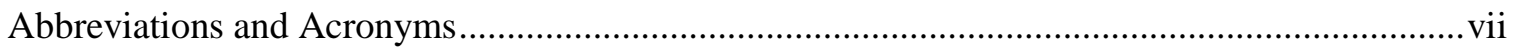

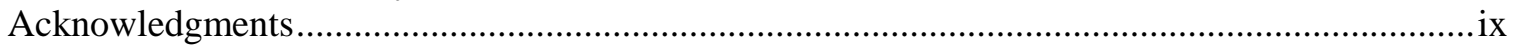

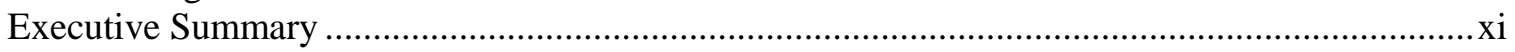

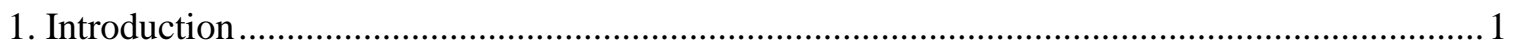

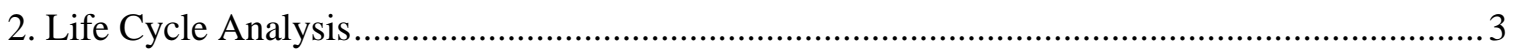

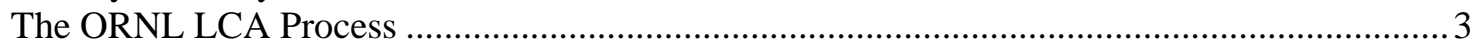

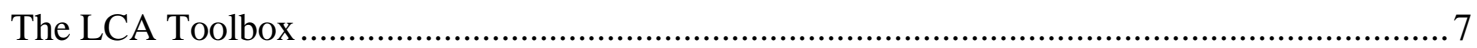

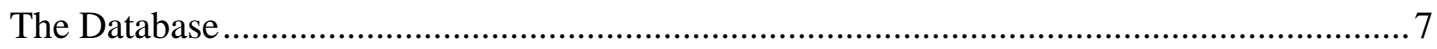

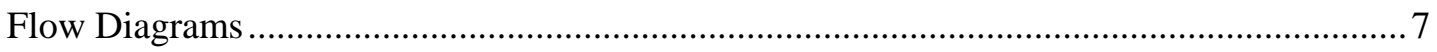

Cost Spreadsheets and Uncertainty and Sensitivity Analysis ........................................... 7

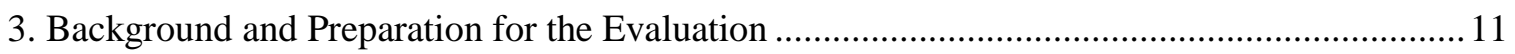

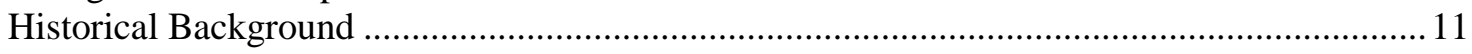

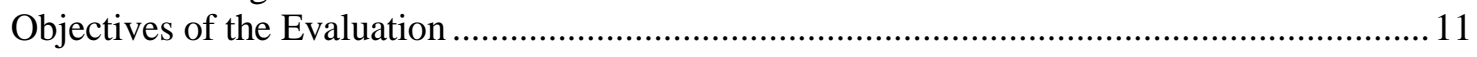

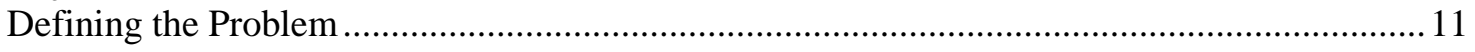

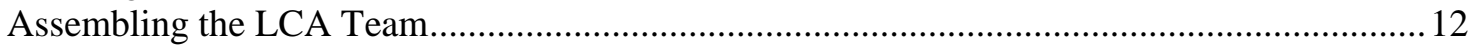

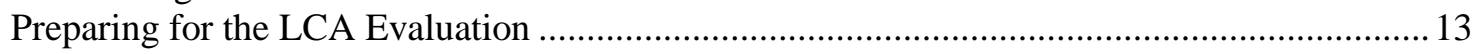

Presentations and Discussions during the Evaluation ........................................................ 13

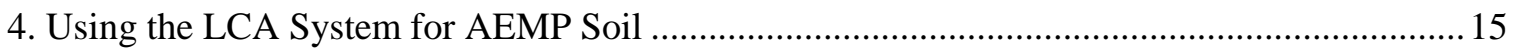

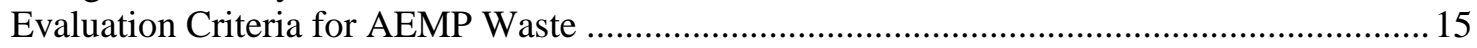

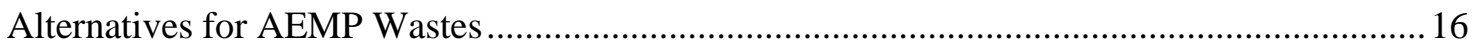

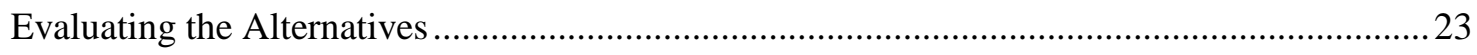

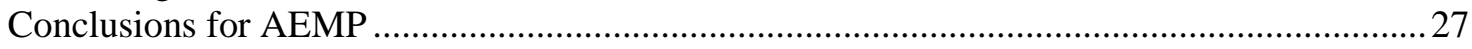

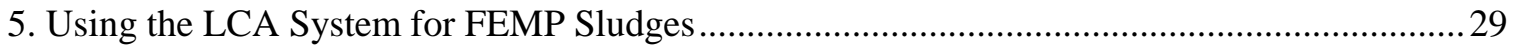

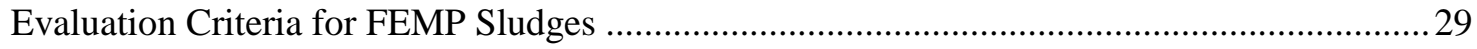

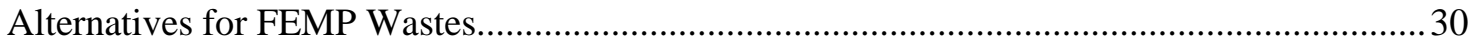

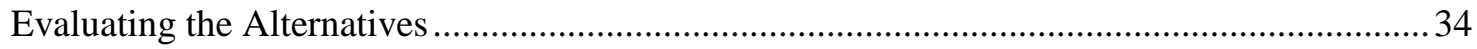

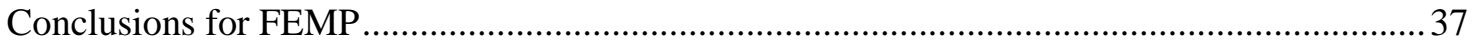

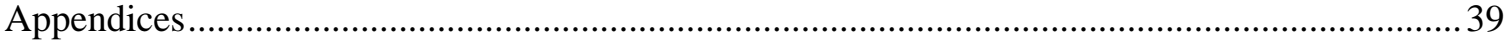

Appendix A — List of Attendees in Ashtabula, June 19-23, 2000 ....................................... 41

Appendix B - Description of EPA Megarule, Technologies, and PCB Permitting ................ 43

Appendix C - Innovative Regulator Role in Site-Specific PCB Problem Solving .................55

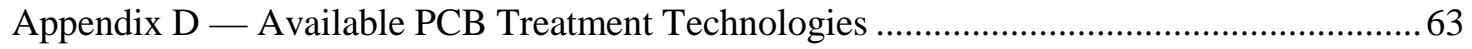

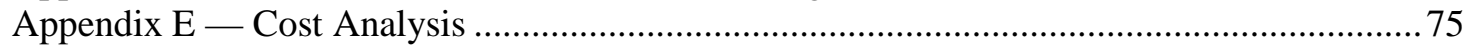

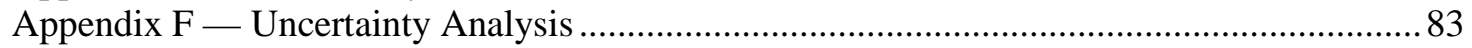




\section{Illustrations}

\section{Figures}

ES.1 The most effective method for disposition of AEMP PCB soils is Alternative 1, direct disposal at the Envirocare mixed waste disposal cell ............................................. xii

ES.2 The most effective disposition pathway for FEMP PCB sludges is commercial treatment off-site

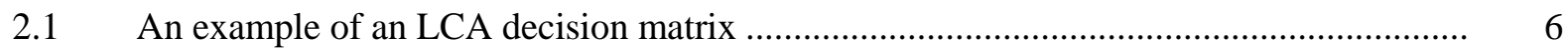

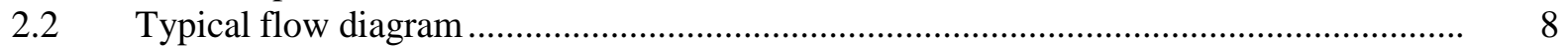

2.3 A frequency chart representing all possible outcomes for disposal of AEMP wastes at Envirocare.................................................................................................. 9

3.1 Logic diagram for selecting a treatment and/or disposal path for PCB waste ................. 14

4.1 Flow diagram for AEMP Alternative 1: Direct disposal at Envirocare ........................... 18

4.2 Flow diagram for off-site treatment options (AEMP Alternatives 2-5) ............................ 19

4.3 Flow diagram for AEMP Alternative 6: Treatment on-site using a molten aluminum process .................................................................................... $\quad 20$

4.4 Flow diagram for AEMP Alternative 7: Treatment on-site using solvent extraction and soil wash

4.5 Flow diagram for AEMP Alternatives 8A, B, and C: Waste storage followed

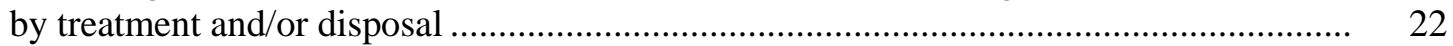

4.6 Summary of evaluation of alternatives for AEMP..................................................... 23

5.1 Flow diagram for FEMP Alternatives 4A and 4B: Treatment on-site ............................. 33

5.2 Summary of evaluation of alternatives for FEMP sludges ............................................

\section{Tables}

4.1 Summary of performance objectives and measures for AEMP …................................. 16

4.2 AEMP decision matrix: PCB treatment and disposal alternatives .................................... 24

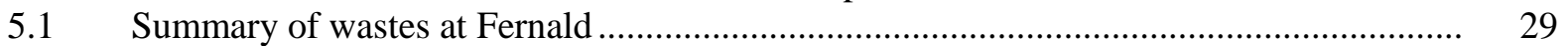

5.2 Summary of performance objectives and measures for FEMP ..................................... 31

5.3 FEMP decision matrix: PCB treatment and disposal options ......................................... 35

\section{Sidebars}

The Steps in Life Cycle Analysis................................................................................... 5

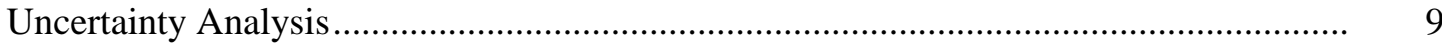




\section{Abbreviations and Acronyms}

$\begin{array}{ll}\text { AEMP } & \text { Ashtabula Environmental Management Project } \\ \text { AU } & \text { Assets Utilization (ORO) } \\ \text { CERCLA } & \text { Comprehensive Environmental Response, Compensation, and Liability Act } \\ \text { D\&D } & \text { decontamination and decommissioning } \\ \text { DCO } & \text { direct chemical oxidation } \\ \text { DOE } & \text { U.S. Department of Energy } \\ \text { EPA } & \text { U.S. Environmental Protection Agency } \\ \text { FEMP } & \text { Fernald Environmental Management Project } \\ \text { LCA } & \text { life cycle analysis } \\ \text { LLW } & \text { low-level radioactive waste } \\ \text { M\&EC } & \text { Materials and Energy Corporation } \\ \text { MW } & \text { mixed waste } \\ \text { NMR } & \text { National Center of Excellence for Metals Recycle (DOE) } \\ \text { MWFA } & \text { Mixed Waste Focus Area } \\ \text { NRC } & \text { Nuclear Regulatory Commission } \\ \text { OH } & \text { Ohio Field Office (DOE) } \\ \text { ORNL } & \text { Oak Ridge National Laboratory } \\ \text { ORO } & \text { Oak Ridge Operations (DOE) } \\ \text { PCB } & \text { polychlorinated biphenyl } \\ \text { pCi/g } & \text { picocuries per gram } \\ \text { ppm } & \text { parts per million } \\ \text { P2 } & \text { pollution prevention } \\ \text { RCRA } & \text { Resource Conservation and Recovery Act } \\ \text { TCE } & \text { trichloroethylene } \\ \text { UHC } & \text { underlying hazardous constituents } \\ \text { WAC } & \text { waste acceptance criteria } \\ \text { WCS } & \text { Waste Control Specialists } \\ & \end{array}$




\section{Acknowledgments}

We wish to thank the following persons for contributions to this analysis: Scott Altmayer, Helen Belencan, Dennis Cook, David Eaton, John Ganz, Geoff Gorsuch, Jim Griffin, Marian Heffner, Nicholas Hefty, Jim Henderson, Greg Hulet, Jeff Kulpa, Quon Kwan, Adrienne La Favre, Keely Lange, Steve Lopez, Vince Maio, Eric Marsh, Tony Martig, Doug Maynor, Steve Schmucker, John Smith, Beverly Whitehead, and Jennifer Williamson. Doug Maynor of the Ohio Field Office deserves special recognition for his sustained leadership and commitment to determining the best pathways for disposition of PCB-contaminated waste streams at the five Ohio closure sites. Special thanks are also due to Jim Griffin, who cheerfully stepped in at the last minute and did a marvelous job as facilitator for a critical part of the discussions. We also wish to express our appreciation to Earthline Technologies for providing the data and hosting the workshop and for their contributions to the report. Finally, we wish to thank Carolyn I. Moser, our technical editor and writer at Oak Ridge National Laboratory, for pulling this together and making it possible to release the draft report immediately following the LCA workshop. 


\section{Executive Summary}

This report presents the results of a joint effort by the U.S. Department of Energy's (DOE's) Ohio Field Office and Office of Environmental Management Pollution Prevention Team; Oak Ridge National Laboratory's (ORNL's) Center for Life Cycle Analysis; the DOE Office of Science and Technology Mixed Waste Focus Area; and the U.S. Environmental Protection Agency (EPA) National, Regional, and State Programs. The objective of the joint effort was to assist the DOE Ohio Field Office $(\mathrm{OH})$ in determining the best alternatives for disposition of waste streams contaminated with polychlorinated biphenyls (PCBs) at the five OH Closure Sites. The disposition of PCBcontaminated soil at the Ashtabula Environmental Management Project (AEMP) and of sludges containing PCBs as well as contaminants regulated by the Resource Conservation and Recovery Act (RCRA) at the Fernald Environmental Management Project (FEMP) were examined in detail in the four-day study at AEMP. The results of this study, particularly application of the new EPA "megarule" and evaluation of newly available PCB treatment technologies, are also applicable to other DOE sites working to develop paths for disposition of problem waste streams.

The major findings of this effort are as follows:

- Application of a provision of the new EPA megarule should allow AEMP to directly dispose of some $12,500 \mathrm{ft}^{3}$ of PCB-contaminated soil without treatment. Cost avoidance of nearly $\$ 4$ million can be achieved when compared to the initial approach of on-site treatment at AEMP.

- Application of other provisions of the megarule to the existing inventory of PCB waste streams at FEMP will allow reclassification of much of the waste, thereby producing significant cost savings. Specifically, as of August 1998 (the date the megarule was issued), the megarule allows sites to use as-found PCB concentrations and the average concentration from the full volume of a spill to determine the required course of action.

- Treatment of PCB-contaminated solid waste streams through the TSCA Incinerator was not considered to be a viable option for $\mathrm{OH}$ because of the risk to the closure schedules.

- FEMP's current plans to treat its PCB sludges at Materials \& Energy Corporation (M\&EC) in Oak Ridge are validated.

The team used the systems developed by the Center for Life Cycle Analysis to identify and evaluate feasible disposition pathways. The life cycle analysis (LCA) compared alternatives by considering their financial, health and safety, environmental, programmatic, and institutional impacts in order to identify the preferred disposition pathway. Details of the analysis for the two representative problem waste streams are described in the following narrative.

\section{Treatment and Disposal of Ashtabula Environmental Management Project (AEMP) Wastes}

AEMP has 12,500 $\mathrm{ft}^{3}$ (615 tons) of soil contaminated with, or suspected to be contaminated with, PCBs (>50 parts per million [ppm]) and radioactive elements (uranium $>30$ picocuries/gram [pCi/g]). Most of this soil came from four grid locations in the floodplain of Fields Brook; the Fields Brook area is the subject of a separate CERCLA remediation effort. The soil was excavated beginning in August 2000 and is currently stored in intermodal containers on-site for subsequent treatment and/or disposal either on- or off-site. 
AEMP has investigated several options for treatment of its soil waste stream, which contains PCBs and low-level radioactive waste (LLW). In November 1999 AEMP requested OH assistance in organizing and performing an LCA of the viable options, including assessment of the full cost to DOE and of significant risks and other factors that should be included in the decision.

AEMP hosted the LCA meeting, which brought together key groups with input to the decision process: DOE managers, prime contractors, EPA regulators, experts in technology and regulations from ORNL and the Mixed Waste Focus Area, and others. The group investigated the regulatory framework for direct disposal of PCBs and for incineration and explored application of the EPA megarule to the AEMP soil waste stream. As a result of fruitful discussions and the use of the systematic LCA process, the group determined that the most practical and cost-effective solution is the course of action labeled Alternative 1- direct disposal at Envirocare's mixed waste disposal cell (with an estimated life cycle cost of $\$ 820,000-\$ 910,000)$. The outcome of the meeting was agreement on a solution that saves $\mathrm{OH}$ nearly $\$ 4$ million relative to the initial approach of on-site treatment at AEMP using a molten aluminum process.

Figure ES.1 presents the eight alternatives the project team developed and evaluated for disposition of the AEMP soil waste stream, the estimated cost range for each alternative, and the accompanying risks associated with each alternative.

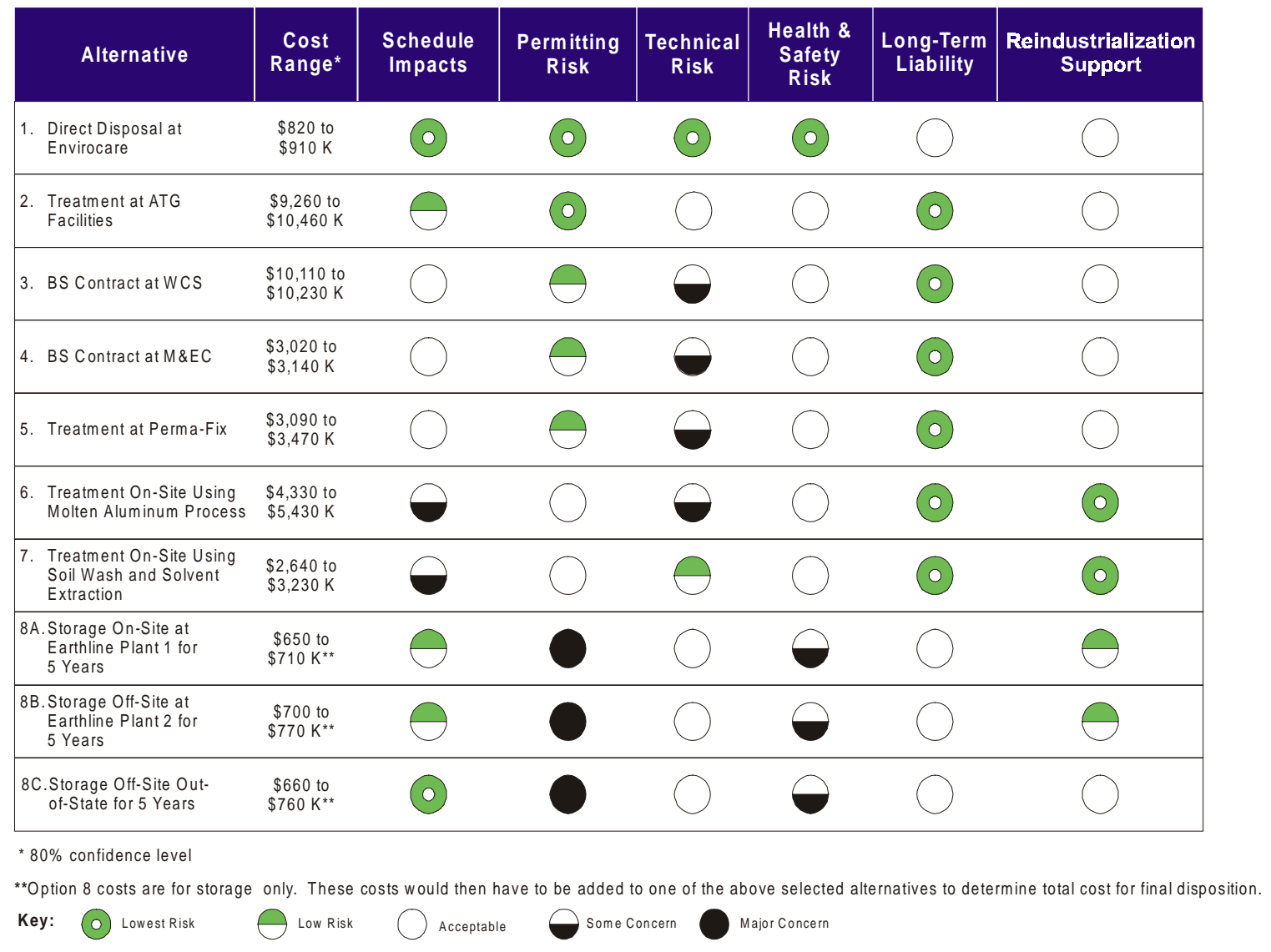

Fig. ES.1. The most effective method for disposition of AEMP PCB soils is Alternative 1, direct disposal at the Envirocare mixed waste disposal cell. 


\section{Treatment and Disposal of Fernald Environmental Management Project (FEMP) Wastes}

FEMP has 229,000 lb of contaminated sludge that contains PCBs (at 50-500 ppm), RCRA-listed contaminants [lead, cadmium, barium, TCEs (F-listed)], and LLW. The project team analyzed possible treatment and disposal approaches and developed five alternatives for detailed evaluation:

1. treatment using ATG's facilities and processes in Richland, with final disposal at Envirocare;

2. treatment using the Broad Spectrum treatment contract at M\&EC in Oak Ridge, with final disposal at Envirocare;

3. treatment using Perma-Fix's facilities and processes in Florida, with final disposal at Envirocare;

4. treatment at Fernald provided by a vendor, with final disposal at Envirocare;

5. storage followed by treatment within 5 years.

The results of the analysis, summarized in Fig. ES.2, suggest that commercial treatment off-site is the preferred approach. None of the three off-site treatment facilities evaluated (ATG, M\&EC, or PermaFix) are currently in operation, but they are expected to be in operation by the July 2003 schedule milestone. Based on the current fixed-price Broad Spectrum contract, treatment at M\&EC is the lowest-cost option. Thus, the outcome of this study is validation of FEMP's current plans to treat its PCB sludges at M\&EC.

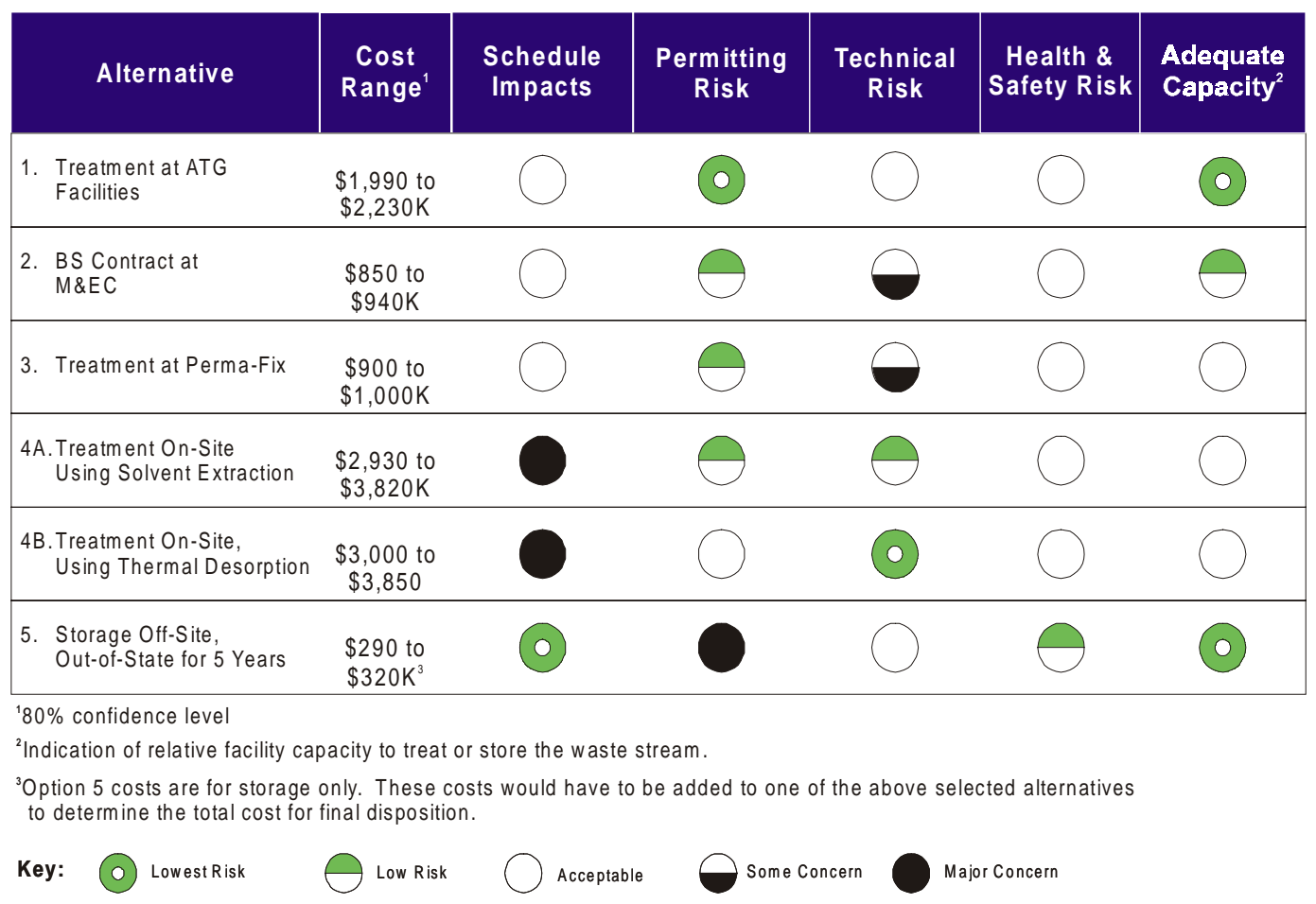

Fig. ES.2. The most effective disposition pathway for FEMP PCB sludges is commercial treatment off-site. 


\section{Conclusion}

The process used for this evaluation as well as the specific conclusions and recommendations presented for AEMP and FEMP provide valuable guidance for other DOE sites that must identify disposition pathways for their waste streams. It is anticipated that other DOE sites will use this process and that the information presented herein will help them make better site-specific decisions. However, this study represents a snapshot of the situation as it currently exists, and the technologies and facilities available for treatment of these wastes are in various stages of development and continue to change. Because of the dynamic nature of the technologies and facilities, we recommend updating the status of the treatment options prior to making decisions in the future on disposition of other DOE waste streams. 


\section{Introduction}

This report presents the use of the life cycle analysis (LCA) system developed at Oak Ridge National Laboratory (ORNL) to assist two U.S. Department of Energy (DOE) sites in Ohio - the Ashtabula Environmental Management Project near Cleveland and the Fernald Environmental Management Project near Cincinnati - in assessing treatment and disposal options for polychlorinated biphenyl (PCB)-contaminated low-level radioactive waste (LLW) and mixed waste. We will examine, first, how the LCA process works, then look briefly at the LCA system's "toolbox," and finally, see how the process was applied in analyzing the options available in Ohio.

As DOE nuclear weapons facilities carry out planned decontamination and decommissioning (D\&D) activities for site closure and progressively package waste streams, remove buildings, and clean up other structures that have served as temporary waste storage locations, it becomes paramount for each waste stream to have a prescribed and proven outlet for disposition. Some of the most problematic waste streams throughout the DOE complex are PCB low-level radioactive wastes (liquid and solid) and PCB low-level Resource Conservation and Recovery Act (RCRA) liquid and solid wastes.

Several DOE Ohio Field Office $(\mathrm{OH})$ sites have PCB disposition needs that could have an impact on the critical path of the decommissioning work of these closure sites. The Ashtabula Environmental Management Project (AEMP), an OH closure site, has an urgent problem with disposition of soils contaminated by PCB and low-level waste at the edge of the site. The Fernald Environmental Management Project (FEMP), another OH closure site, has difficulties in timely disposition of its PCB-low-level sludges and its PCB low-level RCRA sludges in order to avoid impacting the critical path of its D\&D activities. Evaluation of options for these waste streams is the subject of this report.

In the past a few alternatives for disposition of PCB low-level waste and PCB low-level RCRA waste had seemed achievable, but these options did not materialize. Recently, however, new PCB waste treatment alternatives have appeared, and some regulatory requirements for treatment and disposal of PCBs have been relaxed. This LCA evaluation has been performed to assess new and existing PCB waste opportunities that are available for the treatment and disposal of wastes at AEMP and FEMP. 


\section{Life Cycle Analysis}

ORNL's Center for Life Cycle Analysis has developed an LCA system that provides a systematic, comprehensive, cost-effective decision-aiding process and a complementary suite of tools that has been proven to help DOE make better decisions. The LCA system is a powerful decision support methodology that is especially valuable for identifying, assessing, and comparing material disposition alternatives and for selecting and documenting a preferred alternative.

\section{The ORNL LCA Process}

We define LCA as the process of identifying and assessing all categories of benefits and costs that result from a course of action over the entire period of time affected by the action and doing so in a manner that promotes sound decision making. Benefits and costs for options are considered on three levels. The first is a financial level - i.e., the direct financial costs and benefits of the options being considered to address a particular issue or goal. However, if the process stopped at this level, not all costs and benefits of the options would be considered, and poor decisions could result. At the second level, in addition to the direct financial impacts of the alternatives, the quantifiable external effects are considered. These external effects include environmental, public health and worker safety, indirect economic, and socio-institutional impacts. In some cases these external impacts can be quantified and reduced to dollar values. Methodologies such as contingent valuation and conjoint analysis can sometimes be used to place a dollar value on avoiding environmental damages. Indirect economic impacts can be assessed by, for example, input/output models; and health and worker safety issues can be evaluated using a variety of methodologies. In other cases, however, we have no appropriate way to place a dollar value on these external impacts. Nevertheless, those impacts may be very important to the decision maker and to the communities that will be affected by DOE's decisions. Thus, a third level of analysis is often required to make an informed decision. This third level will consider all direct financial costs and benefits, all quantifiable external costs and benefits, and nonquantifiable effects and considerations. For example, socio-institutional impacts often are nonquantifiable, but may be important to DOE decisions.

The ORNL approach to LCA differs from other approaches by taking into consideration all the factors important to decision makers (e.g., life cycle cost, health and safety, the environment, programmatic impacts) over the entire life cycle. By considering all costs and benefits, regardless of which organization pays those costs or realizes those benefits, LCA can produce superior decisions for DOE. Consideration of the various impacts associated with a decision need not in all cases be extensive or excessively burdensome; it should be commensurate with the potential benefits of an indepth analysis and consistent with the resources available for assessing the alternatives. However, the fundamental process of considering each of the alternatives on each of their relevant attributes will help to ensure that all factors important to the decision have been considered, thereby reducing the likelihood of unintended consequences. Only by considering all impacts of decisions over the total life cycle, can managers be confident that they are determining the wisest choice for DOE.

DOE program managers do not have the time and the resources to conduct exhaustive data collection and assessment efforts to evaluate all potential alternatives over all potential decision criteria related to the disposition of facilities and capital assets. They need a practical and streamlined yet analytically structured approach to this class of decision problems. Specifically, the decision-aiding approach itself needs to meet these criteria: 
- Cost-effectiveness. Data needed for the LCA system must be straightforward to collect, and the collection efforts must not require undue time and money. The process must be systematic and easily implemented.

- Comprehensiveness of decision factors. The LCA system needs to encompass a range of decision factors to allow decision makers to understand the complex context of their decisions.

- Defensible results. The outputs of the system must be rigorous and replicable.

- Standardization. The approach must be standardized so that cross-site and cross-program comparisons are possible.

- Robustness. The approach must be applicable to $\mathrm{D} \& \mathrm{D}$, pollution prevention, and asset recovery across the DOE complex.

- Transparency. The process must be understandable and the basis for the decision clear.

The Center for Life Cycle Analysis has developed an LCA approach that meets these criteria.

The ORNL LCA approach has its foundations in the field of decision analysis. The goals of decision analysis are to help people understand the problems they face, construct decision alternatives (options) to solve the problems, specify criteria (attributes) over which to evaluate decision alternatives, and make trade-offs among decision alternatives and criteria to arrive at reasonable and defensible decisions. The LCA approach considers each of the alternatives on each of the relevant attributes to ensure that all effects are considered when making decisions and to reduce the likelihood of unintended and unforeseen consequences.

The process itself involves five steps:

1. defining the problem,

2. specifying criteria on which to evaluate possible solutions,

3. identifying the alternative possible solutions,

4. evaluating the alternatives on the basis of the criteria that have been established, and

5. making the decision.

These steps are elaborated in the sidebar. Although presented here as a linear process, the process is in fact iterative. For example, we typically perform a quick initial investigation, and this will suggest new, improved decision alternatives for evaluation.

Stakeholder involvement is a key issue in every LCA. At the beginning of a typical LCA process, a judgment is made as to the appropriate extent of stakeholder involvement in the decision-making process. For noncontroversial decisions of small consequence, decisions are frequently based simply upon recommendations of analysts. For decisions of more consequence that need cooperation from community leaders and/or regulators, an "elite-corps" decision process may be warranted. For decisions that have ramifications for the entire community, more time and effort to involve the broadest spectrum of stakeholders is desirable.

In situations where stakeholders do need to be involved, problems will arise if they are not involved early and often. Stakeholders cannot be brought into the LCA process at the back end, provided the results, and asked for their opinions. On principle alone, the stakeholders will be motivated to be argumentative, resistive, and disruptive. Successful participation efforts bring stakeholders into the process in the beginning. In the decision context being explored in this report, early involvement may focus on specifying threshold criteria that must be met (e.g., compliance with waste acceptance criteria), specifying evaluation criteria, and identifying any assets (e.g., buildings) that should receive priority attention. 


\section{THE STEPS IN LIFE CYCLE ANALYSIS}

1. Defining the Problem - LCA begins by assembling a project team. Its members then work together to clearly state the problem that needs solution. This step focuses on (1) ensuring that we are addressing the real problem, not merely a symptom; (2) specifying the scope of the study and the inventory to be addressed; and (3) getting all those involved in the decision making process familiar with the issue and involved in the process from the beginning. In the case of highly participative decision making, many more people will be involved in helping confront the issue than were involved in identifying the issue. Thus, many people may need to be introduced to the issue under consideration.

\section{Specifying Criteria for Evaluating Possible Solutions - The second step involves specifying} criteria by which to evaluate the decision alternatives. The criteria should be developed by the project team appropriate to the problem being considered. But to standardize D\&D decision making and to make the process systematic and easily implemented, it helps to have a core set of criteria that are always considered in D\&D decision-making. ORNL has developed a core set of six criteria: life cycle cost, pollution or waste generated, environmental impacts, health and safety impacts, programmatic impacts, and institutional impacts.

3. Constructing the Alternative Possible Solutions - For better-known issues, the alternatives may already be well known and defined. In other cases, alternatives considered in other but similar situations may be borrowed for consideration. At times, the D\&D problem may be unique and so complex that a structured brainstorming process may be required to generate alternatives. The set of alternatives should include alternatives that are reversible, are multipronged (i.e., entail a portfolio of actions to improve learning potential and to guard against unexpected events), and are a synthesis of actions over time. In situations of great uncertainty, alternatives employing an incremental strategy should be included: small steps, monitoring, reassessment, additional small steps, etc.

4. Evaluating the Alternatives - In the fourth step analytical methods are used to evaluate how well each alternative satisfies each evaluation criterion. To begin, a detailed material flow diagram is drawn for each alternative. The flow diagram includes every step in the life cycle, regardless of the organization involved or the time at which it occurs. Only after every step in the life cycle has been identified can we be confident of making a fair comparison of the financial, environmental, health and safety, and other impacts of the alternatives.

Uncertainty analysis is performed to take into consideration the uncertainty in the underlying variables and provide a truer picture for decision makers. Frequency charts describe the range of possible outcomes and the likelihood of occurrence. Sensitivity analysis and value-of-information analysis are used to determine where additional investigation is warranted - i.e., does the potential benefit of additional investigation justify the cost of obtaining the information? An iterative process is used in which decision alternatives are revised as preliminary analysis suggests new, better alternatives.

5. Making the Decision - Often, after participants have gone through the preceding steps, with iterations to develop improved alternatives, the decision becomes clear. Arriving at reasonable and defensible decisions, however, may be challenging in situations where none of the decision alternatives is dominant. If no alternative is best on every criterion, it may be possible to mount a logical argument in support of one of the alternatives. Or it may be possible to eliminate alternatives that do not meet minimum criteria thresholds. After one or more alternatives have been eliminated, it may be clear which of the remaining alternatives is preferred.

In situations where it is difficult to identify a preferred alternative, the alternatives can be ranked using multi-attribute decision analysis, in which the results of the LCA are combined with weighting factors to produce an aggregate score for each alternative. The weighting factors reflect judgments regarding the relative value of making improvements according to one criterion (e.g., life cycle cost) relative to making improvements according to another criterion (e.g., programmatic impacts). Ideally, the weighting factors are defined through a consensual process that includes stakeholders.

Analyses are also performed as part of this step to identify conditions under which the rank order of the alternatives would change. Finally, LCA uses a variety of visualization techniques to synthesize all the information and communicate the results. 
It always becomes apparent in stakeholder discussions that different people attach differing degrees of importance to the evaluation criteria and may therefore end up with different preferences for alternatives. One strength of the LCA approach is that discussions of the decision under consideration can be augmented to show the weights assigned to each criterion by different stakeholders. Then everyone in the room will be able to understand, as explicitly as our language and communication skills allow, where everyone one else in the room stands with respect to values and preferred decision outcomes. Discussions could ensue to craft a consensus on an alternative. New alternatives could be explored that could bridge the gaps among stakeholders.

The results of an LCA are summarized in a decision matrix similar to the one shown in Fig. 2.1. This is an LCA decision-aiding framework that provides a proven structure to organize data pertinent to the decision. The rows of the matrix list the decision alternatives, and the columns, the decision criteria. The cells of the matrix hold the assessments of how well a particular alternative meets a particular criterion. On the basis of the evaluation, the preferred alternative is then identified.

\section{Hypothetical Analysis of Asset Utilization Proposal}

\begin{tabular}{|c|c|c|c|c|c|}
\hline Alternatives & $\begin{array}{l}\text { Life Cycle } \\
\text { Cost }\end{array}$ & $\begin{array}{l}\text { Environmental } \\
\text { Impacts }\end{array}$ & $\begin{array}{l}\text { Public \& Worker } \\
\text { Health \& Safety }\end{array}$ & $\begin{array}{c}\text { Pollution/ } \\
\text { Waste Prevented }\end{array}$ & $\begin{array}{c}\text { Programmatic } \\
\text { Impacts }\end{array}$ \\
\hline Baseline Process & $\$ 1 \mathrm{M}$ & & & & \\
\hline Proposed Process & $\$ 0.5 \mathrm{M}$ & & & & \\
\hline
\end{tabular}

Key: Relative to baseline approach, alternative produced:

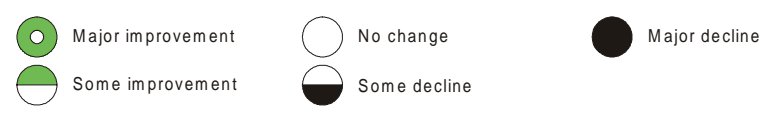

Fig. 2.1. An example of an LCA decision matrix.

The real world complicates the implementation of this simple model in many ways. Often, time and money constraints limit the amount of data that can be collected for input into a decision analysis, the number of alternatives that can be considered, and the sophistication of the models used to evaluate alternatives over decision criteria. Policy issues surrounding decision contexts often influence how (and maybe even whether) the results of decision analyses are ultimately used.

The approach presented here addresses these major problems. First, the approach is as streamlined as possible. Only the minimum amount of information needed to make reasonable and defensible decisions is collected. Standard spreadsheet tools are used to support quantitative analyses. Other decision inputs are based on the judgments of subject matter experts, decision makers, and relevant stakeholders. Second, the approach makes as transparent as possible the values people place on various evaluation criteria. This fosters involvement of multiple stakeholders and communication of their values to other stakeholders. Given that public participation is becoming more important in all aspects of environmental decision making, this is an especially important aspect of this approach. 


\section{The LCA Toolbox}

The LCA system as developed by ORNL includes numerous tools that provide a wide variety of methods for evaluating costs and benefits of alternative problem solutions. For example, ORNL has developed tools to help model processes, estimate human health and ecological risks, estimate costs, and represent uncertainties.

The primary tools used in the evaluation of waste disposition alternatives for AEMP and FEMP were

- a database containing cost and other information about the technology options;

- flow diagrams for each of the possible solutions; and

- customized spreadsheets to calculate all the cost elements defined in the flow diagrams and software allowing uncertainty and sensitivity analyses.

\section{The Database}

A crucial tool in the analysis process is the database. As part of this work, the Center for Life Cycle Analysis at ORNL developed a database of information to support decision-making. To construct the database, we assembled and validated cost information that currently resides in multiple sources of printed materials. The goal is to have a source of validated data that can be used to evaluate projects within DOE and support material disposition decisions.

\section{Flow Diagrams}

Flow diagrams are an essential part of the life cycle analysis process. They are developed to track all activities, energy, and material flows associated with the life cycle of a product, a project, or a policy proposal. Tracking material flows is a fairly standard aspect of LCA. Our approach is different in that we also track material flows associated with decisions. For example, to assess the costs and benefits of decisions related to the disposition of unused materials at DOE sites, we develop flow diagrams associated with each decision alternative (e.g., to dispose of slightly radioactive metals in a burial site or to recycle the metals into products usable by government and/or industry). Figure 2.2 illustrates a typical flow diagram used in this type of analysis.

\section{Cost Spreadsheets and Uncertainty and Sensitivity Analysis}

New methods for analyzing and presenting the results of life cycle analysis can help decision makers make better-informed, more accurate, and more defensible decisions. Traditionally, cost estimates were based upon single-point estimates. A spreadsheet model was developed that calculated the expected cost of the project.

This type of presentation neglects the uncertainties involved, however. It therefore does not present a true picture and may lead to poor decisions. This report demonstrates how to improve the analysis of project costs by taking into consideration the uncertainty in the underlying variables. By presenting a more realistic picture of the costs of any proposal, this approach will help D\&D managers move to the next level of decision-making confidence.

In this new approach, we no longer rely on single-point estimates. We begin by designing and building customized spreadsheets using data from the database to calculate all the cost elements defined in the flow diagrams for each of the alternatives. Then, using a software program called Crystal Ball, we replace each of the uncertain variables in our cost model with a range of possible values. Each value in the range has a probability of occurrence. A simulation is then run, simulating thousands of potential outcomes by running thousands of trials. The result is a frequency chart that 


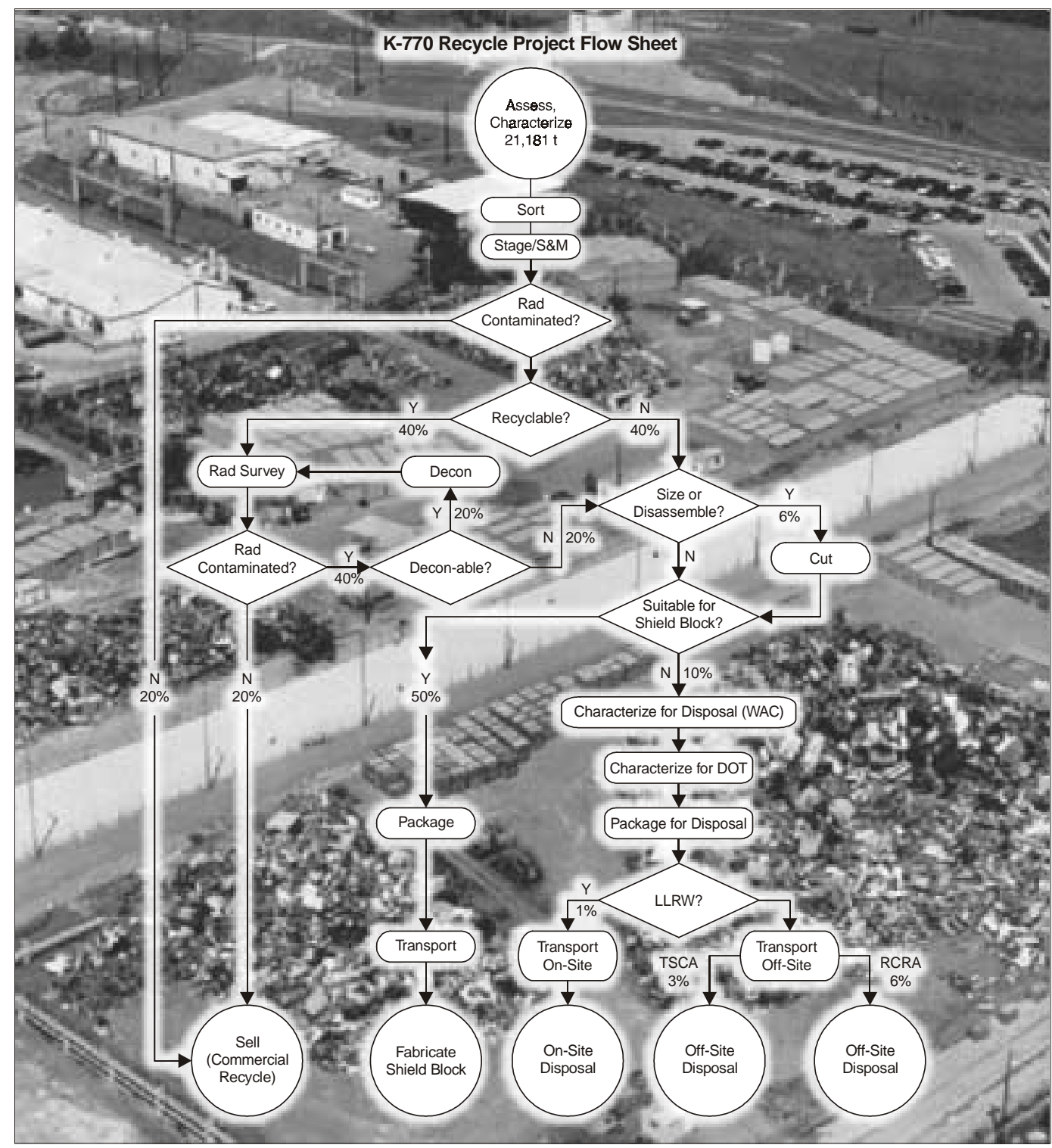

Fig. 2.2. Typical flow diagram.

represents all of the possible outcomes. Using this frequency chart, decision makers can determine not only the range of possible outcomes but also the likelihood of occurrence.

For example, Fig. 2.3 is a frequency chart displaying the expected range of costs for direct disposal of the $12,500 \mathrm{ft}^{3}$ of AEMP PCB wastes at an $80 \%$ confidence level. The total cost of direct disposal is expected to be between $\$ 820,000$ and $\$ 910,000$ at an $80 \%$ confidence level. To determine which uncertain variables have the greatest impact on the results, we perform a sensitivity analysis. For example, in the case of direct disposal, sensitivity analysis reveals that the disposal fee is the major cost driver. In all the other alternatives evaluated, the treatment cost is the major cost driver. 


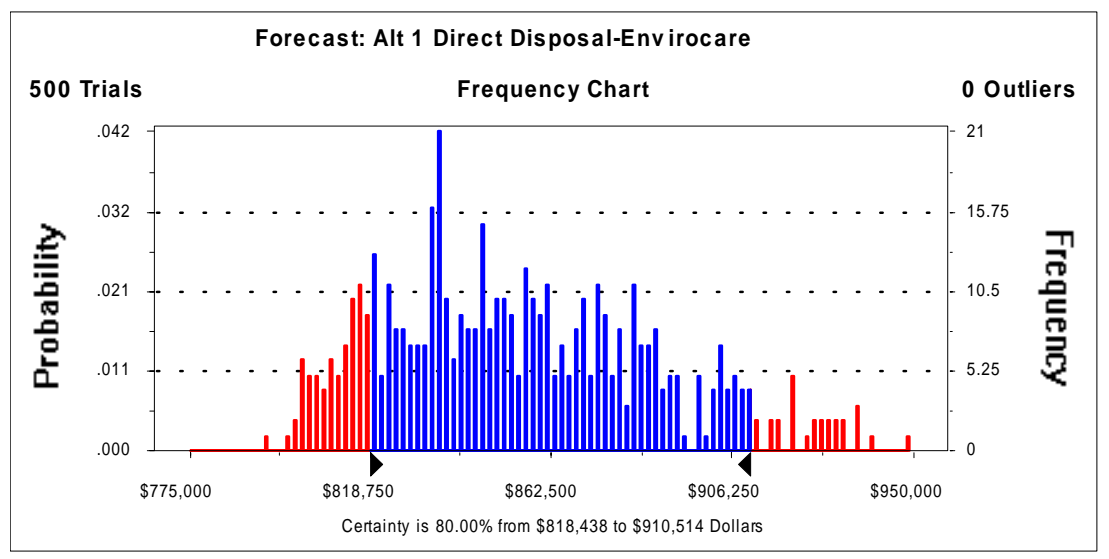

Fig. 2.3. A frequency chart representing all possible outcomes for disposal of AEMP wastes at Envirocare. At an $80 \%$ confidence level, the cost of disposal is expected to be between $\$ 818,000$ and $\$ 911,000$.

\section{UNCERTAINTY ANALYSIS}

Companies have used spreadsheets in making business decisions since the 1980s. However, spreadsheet programs have two major limitations:

- The user can change only one spreadsheet cell at a time.

- "What-if" analysis results in single-point estimates that do not indicate the likelihood of achieving a particular outcome.

In order to overcome these limitations, the user must be able to describe a range of possible values for each uncertain cell in the spreadsheet and have a way to measure the effects of these uncertainties.

Uncertainty analysis software is used to help overcome these two limitations. We use a graphically oriented forecasting and risk analysis program to extend the capabilities of our spreadsheets. The program allows us to describe a range of possible values for each uncertain cell in our spreadsheet; everything we know about each input value is expressed all at once. Once we have described our uncertainties, the program uses Monte Carlo simulation to display results in forecast charts that show the range of possible outcomes and the likelihood of achieving each of them. This allows us to provide a statistical picture of the range of possibilities for our assumptions rather than just single-point estimates. 


\section{Background and Preparation for the Evaluation}

\section{Historical Background}

Of the five $\mathrm{OH}$ sites, AEMP has perhaps the most urgent need to resolve the disposition of its PCB wastes, but other sites such as FEMP also have urgent milestones to meet - in the case of the Fernald site, disposal of PCB low-level RCRA sludge.

AEMP has investigated several options for treatment of its PCB low-level soil waste stream. In November 1999 AEMP requested $\mathrm{OH}$ assistance in organizing and performing an LCA of the viable options, including assessment of the full cost to DOE and of significant risks and other factors that should be included in the decision.

$\mathrm{OH}$ agreed to organize an LCA evaluation and wanted to expand the scope to include evaluation of other OH PCB waste streams and participation of other OH sites. In February 2000, OH answered a call for pollution prevention (P2) proposals from EM-22 and proposed to evaluate alternatives for several PCB waste streams. In March EM-22 awarded OH additional funding for this evaluation.

\section{Objectives of the Evaluation}

The objectives of this LCA evaluation were to

- describe realistic alternatives and relevant requirements in an orderly and systematic manner;

- by using an LCA approach, quantify the associated costs and risks of the viable alternatives as much as possible; and

- $\quad$ provide guidance to operational decision makers at the various DOE sites

\section{Defining the Problem}

In this LCA two different case studies were performed. The selected waste streams are considered to be typical of PCB, low-level, and mixed waste streams in the DOE Ohio region and throughout the entire DOE complex. The two cases were evaluated separately and independently.

Case 1 - AEMP: PCB low-level contaminated soil: The work required at AEMP consists of the disposition and possible treatment of $12,500 \mathrm{ft}^{3}$ (615 tons) of soil. The soil is contaminated with, or suspected to be contaminated with, PCBs (>50 parts per million [ppm]) and radioactive material (uranium $>30$ picocurie/gram $[\mathrm{pCi} / \mathrm{g}]$ ). Most of this soil is found in four grid locations in the floodplain of Fields Brook, which runs along the edge of the property. The Fields Brook area is the subject of a separate CERCLA remediation effort. The soil is wet and will be excavated beginning in August 2000. The excavated soil will be stored in intermodal containers on-site for subsequent treatment and/or disposal either on-site or off-site.

Case 2 - FEMP: Low-level RCRA sludges with and without PCBs: The work required at FEMP consists of the disposition and possible treatment of 229,000 lb of contaminated sludge at Fernald, near Cincinnati, Ohio. The sludge contains PCBs (50-500 ppm), RCRA-listed contaminants [lead, cadmium, barium, TCEs (F-listed)], and low-level radioactive waste. 


\section{Assembling the LCA Team}

Consistent with the LCA philosophy to obtain broad involvement in the LCA evaluation process, $\mathrm{OH}$ recruited the following individuals to participate in this LCA:

- a planning team to organize and prepare for the week of evaluation at Ashtabula, as described below;

- experienced $\mathrm{OH}$ site waste management and technology managers (DOE and contractors) to represent the sites' problems and past efforts;

- U.S. Environmental Protection Agency (EPA) participants from Headquarters, Region V, and the state of Ohio to describe the current EPA regulations for treatment and disposal of PCB wastes and RCRA wastes.

For the planning team, $\mathrm{OH}$ enlisted the support of

- Kathy Yuracko and Mike Morris, of ORNL's Center for Life Cycle Analysis, for expertise in the LCA process and familiarity with technologies;

- David Eaton and Vince Maio, and later also Greg Hulet and Steve Lopez, of the Mixed Waste Focus Area (MWFA), for regulatory and technology expertise;

- Dick Govers, of the Chamberlain Group, for assistance in coordinating and managing the project;

- Scott Altmayer, of Earthline Technologies (ET), for expertise in technology development and waste management, familiarity with the AEMP site, and logistics coordination as the host site, as well as several others from ET who joined in the on-site discussions;

- Jim Griffin, representing DOE Columbus, who stepped in at the last minute to serve as facilitator for a critical part of the discussions;

- Dennis Cook of Fluor Fernald and Steve Schmucker of Battelle Columbus, who contributed greatly with their site experiences and expertise in mixed and PCB waste management; and

- the D\&D Focus Area, represented by Nicholas Hefty of Florida International University, who provided additional information on existing and developing technologies and additional background on PCB regulation.

DOE Headquarters also participated in planning and discussions:

- EH-41 (represented by Beverly Whitehead and Energetics' Quon Kwan) supported the involvement of EPA Headquarters and also provided EH's insights into the current regulations.

- EM-22 (Helen Belencan) was involved in the planning process and assisted in introducing the PCB LCA process to other DOE sites.

- EM-13 (Keely Lange) participated and observed the process to provide feedback to DOE senior management and for future interaction with congressional staff.

EPA regulators were invited to present information and join in the discussions, and they graciously consented:

- John H. Smith, of EPA Headquarters, author of the PCB "megarule," explained the details and advantages of the new regulations.

- Tony Martig, of EPA Region V in Chicago, highlighted the requirements for TSCA permitting.

- Adrienne La Favre, of Ohio EPA, discussed a summary of RCRA permitting requirements as they apply to AEMP. 
$\mathrm{OH}$ also suggested the participation of the DOE Chicago Operations Office and the DOE Portsmouth site. Of the total of eight sites or DOE offices that had been expected to participate in the week-long evaluation at Ashtabula, three of the five $\mathrm{OH}$ sites and the $\mathrm{OH}$ field office did participate; and excellent discussions, evaluations, and conclusions resulted. The full list of participants at Ashtabula on June 19-23, 2000, is found in Appendix A.

\section{Preparing for the LCA Evaluation}

In preparation for the LCA evaluation, a database of the PCB low-level waste streams was compiled. The database included a description of each waste stream, including its volume and pertinent characteristics. Each site representative also prepared a discussion of that site's PCB waste streams and of past difficulties in obtaining resolution of each.

In order to help all participants to work toward a common goal, the MWFA group posted on its web site several key documents that helped communicate the goal of the evaluation: the creation of a draft LCA setting forth concrete goals and priorities for evaluating the many OH PCB waste streams, the waste matrix, information on various technologies that were considered potential solutions, and other relevant information.

In order convey the requirements for treatment and/or disposal of PCB low-level wastes, a logic diagram was prepared. Requirements were broken down into three categories according to type of waste: (1) nonhazardous PCB low-level wastes, which may qualify for direct disposal without treatment under the EPA megarule; (2) PCB low-level wastes containing RCRA-characteristic constituents only or characteristic and listed constituents; and (3) PCB low-level wastes containing only RCRA-listed hazardous components. Figure 3.1 provides the logic diagram for selecting the path for treatment and/or disposal of these three categories of waste.

\section{Presentations and Discussions during the Evaluation}

At the start of the evaluation, the major PCB waste streams from the $\mathrm{OH}$ sites were described. Then the EPA representatives presented and discussed information on relevant regulations. In particular, the EPA megarule of August 1998, as further clarified in 1999, allows for direct disposal under certain circumstances of bulk product and remediation PCB low-level radioactive wastes in a licensed landfill facility such as Envirocare, Hanford, or the Nevada Test Site. John H. Smith of EPA, the primary author of the megarule, led an excellent discussion on this subject during the evaluation at Ashtabula. His slides and other presentations during that evaluation are provided on the MWFA web site, at http://nllw.inel.gov/mwfa-files. Additional information may be found in Appendix B.

On the second day, ORNL and MWFA led discussion about relevant treatment technologies that exist or are being developed. The group then agreed to concentrate on resolving a path forward for AEMP's PCB low-level soil and FEMP's PCB low-level and PCB low-level RCRA sludges. The remainder of the report provides the results of those discussions. A detailed discussion of the meeting published by the DOE Office of Environmental Policy and Guidance, RCRA/CERCLA Division, is provided in Appendix C. 


\section{Non-Liquid PCB/Radioactive Waste Landfill Disposal}

Diagram

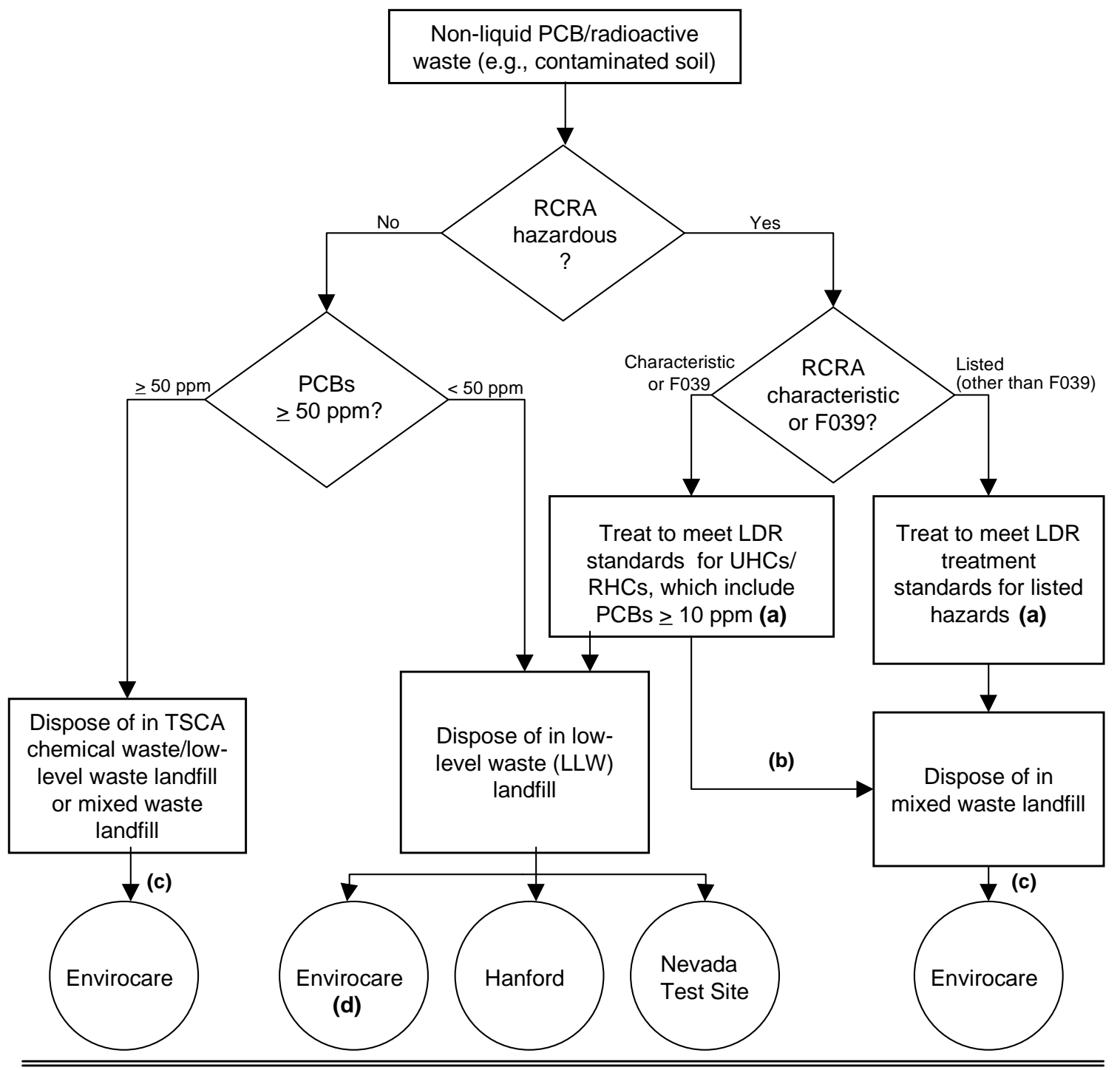

RHC = Regulated Hazardous Constituent (40 CFR 268.40)

$\mathrm{UHC}=$ Underlying Hazardous Constituents [40 D+CFR 268.2 (I)]

UTS $=$ Universal Treatment Standards (40 CFR 268.40 or 268.48)

(a) Assuming the state has not adopted the alternative LDR treatment standards for contaminated soil (40 CFR 268.49). If state has adopted these standards, then hazardous constituent concentrations must be reduced by $90 \%$ with treatment capped at 10 times UTS [40 CFR 268.49(c)]. For non-wastewater PCBs this translates into a cap of $100 \mathrm{mg}^{\mathrm{kg}} \mathrm{kg}^{3}$ total PCB concentration. Note: EPA has proposed to exempt toxicity characteristic metal-contaminated soil from the requirement to treat PCBs as UHCs.

(b) Assuming F039 waste stream. Also, this becomes the pathway if the state has adopted the alternative treatment standards for contaminated soils (40 CFR 268.49) and the treatment results in PCBs > 50ppm or a hazardous constituent that is above the TCLP level.

(c) NTS and Hanford sites have PCB-mixed waste disposal capability for their own wastes. Steps are being taken to allow use of these facilities by other sites within several years. However, this capability is not currently available.

(d) Envirocare may not accept decharacterized (formally RCRA characteristic) waste for disposal in a LLW landfill pursuant to the terms of its state of Utah permit.

Fig. 3.1. Logic diagram for selecting a treatment and/or disposal path for PCB waste. 


\section{Using the LCA System for AEMP Soil}

\section{Evaluation Criteria for AEMP Waste}

To begin, the group developed two screening criteria that had to be met by all alternatives. Options that did not meet these mandatory requirements were eliminated without further evaluation. The screening criteria were as follows:

- Alternatives had to comply with all regulations and thus not pose a significant risk to achieving regulatory approval(s) and necessary permits.

- The technology of the alternative had to be sufficiently mature to meet the site's schedule. Appendix D summarizes the available technologies.

Next, the group developed a set of site-specific objectives to be used in making the decision:

1. minimize life cycle cost,

2. minimize adverse schedule impacts,

3. minimize permitting risk,

4. minimize technical risk,

5. minimize health and safety impacts,

6. minimize long-term liability,

7. maximize support for reindustrialization.

Next, measures were developed for each objective. These measures were used to estimate how well each alternative achieved each objective. The measures were as follows:

1. Life cycle cost. Performance was measured as the estimated total life cycle cost (to DOE) of the alternative.

2. Schedule impacts. Performance was measured by an estimate of the ability to physically accomplish work to be able to meet the site and project schedule. In the case of AEMP, the $12,500 \mathrm{ft}^{3}$ of PCB low-level soil must be excavated in order to not delay the Fields Brook Comprehensive Environmental Response, Compensation, and Liability Act (CERCLA) cleanup schedule; the deadline presently expected is the end of September 2000. The site's goals are to

- present a plan by the end of CY 2000 for the excavated soil;

- complete treatment and/or disposal by CY 2001 to meet the probable expectations of the Fields Brook CERCLA project (a firm date will probably be established later, but the typical schedule for final disposition of CERCLA waste is one year after excavation); and

- meet the commitment to close the Ashtabula site in 2006.

3. Permitting risk. The estimate of permitting risk was based on the degree of compatibility with regulatory requirements and the likelihood of obtaining permit(s) or avoiding the need for permitting.

4. Technical risk. The estimate of technical risk was based on process maturity, flexibility, robustness, and complexity, and on equipment reliability, operability, and maintainability.

5. Health and safety impacts. The impacts on health and safety were estimated by taking into consideration risks both to workers and to the public.

6. Long-term liability. Long-term liability was based on the likelihood of needing additional treatment after disposal or needing additional environmental cleanup in the future.

7. Reindustrialization impacts. Estimates of reindustrialization impacts were based on expected job creation. 
Table 4.1 summarizes these performance objectives and measures.

Table 4.1. Summary of performance objectives and measures for AEMP

\begin{tabular}{|c|c|}
\hline Objective & Measure \\
\hline Minimize cost & Total life cycle cost \\
\hline Minimize schedule impacts & Estimate of the impact on site/project schedule \\
\hline Minimize permitting risk & $\begin{array}{l}\text { Degree of compatibility with regulatory requirements and likelihood } \\
\text { of obtaining permit(s) or avoiding the need for permitting }\end{array}$ \\
\hline Minimize technical risk & $\begin{array}{l}\text { Estimate on basis of process maturity, flexibility/robustness, and } \\
\text { complexity, and equipment reliability, operability, and } \\
\text { maintainability }\end{array}$ \\
\hline Minimize health and safety impacts & Risk to workers and the public \\
\hline Minimize long-term liability & $\begin{array}{l}\text { Estimated likelihood of needing additional treatment after disposal or } \\
\text { needing additional environmental cleanup in the future }\end{array}$ \\
\hline Maximize reindustrialization support & Expected number of jobs created \\
\hline
\end{tabular}

\section{Alternatives for AEMP Wastes}

Eight alternatives were developed for the AEMP PCB wastes:

Alternative 1: Direct disposal at Envirocare in its mixed waste disposal cell

Alternative 2: Treatment using the facilities and processes of ATG, with final disposal at Envirocare

Alternative 3: Treatment via the Broad Spectrum treatment contract at Waste Control Specialists (WCS), with final disposal at Envirocare

Alternative 4: Treatment using the Broad Spectrum treatment contract at Materials and Energy Corporation (M\&EC), with final disposal at Envirocare

Alternative 5: Treatment using Perma-Fix's facilities and processes in Florida, with final disposal at Envirocare

Alternative 6: Treatment at AEMP using the molten aluminum process of Clean International Technology Corporation, with final disposal at Envirocare

Alternative 7: Separation and treatment at AEMP using a solvent extraction process (Terra Kleen) for removal of PCBs and soil washing for removal of radioactive material; disposal on site for material meeting the waste acceptance criteria (WAC) for on-site radioactive disposal, disposal at the Envirocare low-level waste cell for material not meeting the on-site WAC, and incineration of extracted PCBs at the TSCA Incinerator in Oak Ridge

Alternative 8: Storage for an additional 5 years, followed by treatment by 2006. Three storage options were considered: (a) on-site at Earthline's plant 1 in Ashtabula, (b) off-site at Earthline's plant 2 in Ashtabula, and (c) off-site and out-of-state. 
In addition to the eight alternatives listed above, three other alternatives were discussed but rejected:

1. Treatment at the TSCA incinerator: This option was rejected because there is limited access for out-of-state DOE wastes and limited TSCA Incinerator capacity to treat this large solid-waste volume. Approximately 2-3 years of dedicated use would be required to treat this solid waste stream. Additional considerations:

- TSCA burn plans are subject to approval by the state of Tennessee; Tennessee policy is to deny TSCA Incinerator treatment if another option is available.

- The burn capacity at TSCA Incinerator is about 500,000 lb per year for liquids. For solids, the burn rate is much lower; thus, the time required to burn the AEMP wastes would exceed three years.

- The TSCA incinerator is scheduled to shut down permanently in 2003.

- Tennessee requires TSCA treatment within 30 days of receipt; thus, AEMP would be required to ship its waste in small increments.

2. Direct disposal at Hanford: Hanford has a mixed waste cell, but it does not yet have procedures in place to accept PCB low-level waste. Hanford is obtaining a permit and will complete a sitewide Environmental Impact Statement by the fall of 2001. In addition, although Hanford has been accepted as a site for disposal of PCB low-level waste, Ashtabula is not a grandfathered site for disposal of waste. For this reason, the schedule for receiving waste would be very problematic. Thus, this alternative was eliminated because it probably would not meet Ashtabula's schedule requirements.

3. Plasma hearth process at Ashtabula: Prior to the meeting, AEMP considered the use of a plasma hearth process using equipment available at the site. However, this was eliminated for consideration before the meeting because of the difficulty of permitting an incineration process.

Flowsheets for the eight alternatives are provided in Figs. 4.1-4.5. 


\section{PCB-Radioactive Waste Disposal Alt 1: Disposal Only; No Treatment}

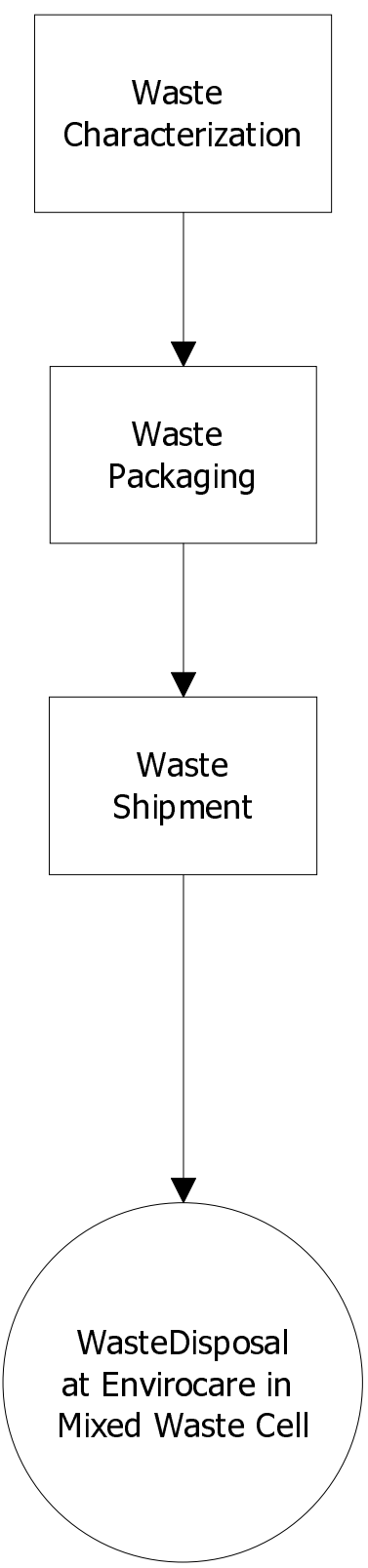

Fig. 4.1. Flow diagram for AEMP Alternative 1: Direct disposal at Envirocare. 


\section{PCB Waste Treatment Off-Site}

Alt 2: ATG

Alt 3: Broad Spectrum WCS

Alt 4: Broad Spectrum M\&EC

Alt 5: Perma-Fix

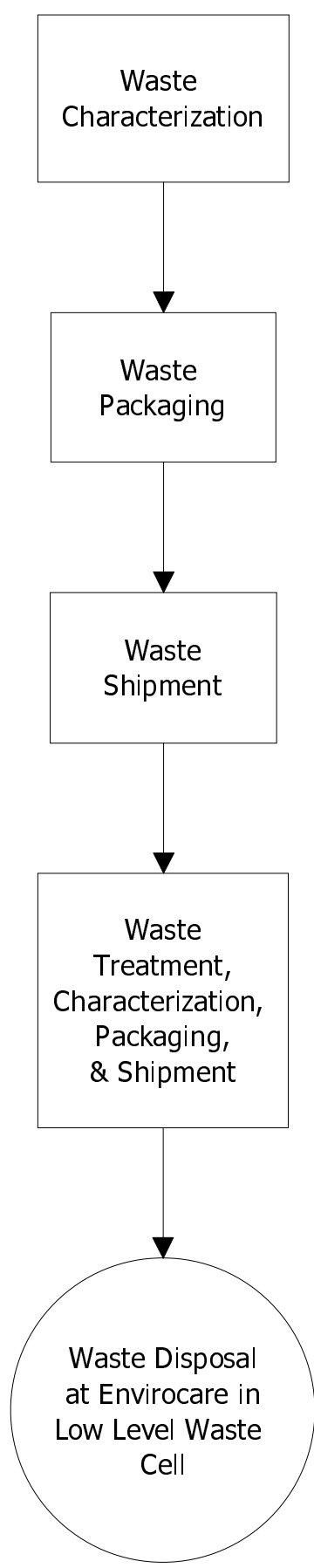

Fig. 4.2. Flow diagram for off-site treatment options (AEMP Alternatives 2-5). 


\section{PCB Waste Treatment On-Site Alt 6: Molten Aluminum "Clean Technology"}

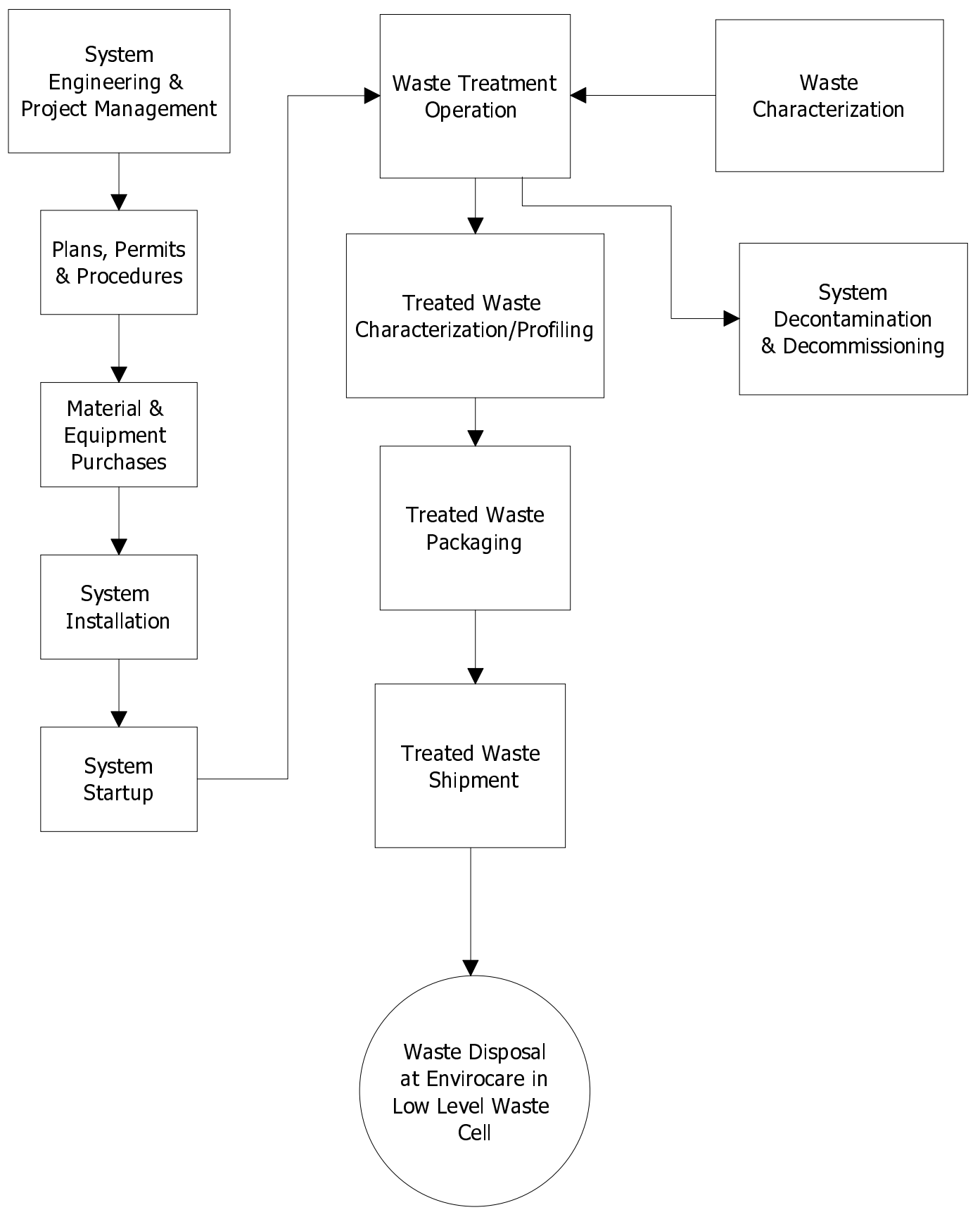

Fig. 4.3. Flow diagram for AEMP Alternative 6: Treatment on-site using a molten aluminum process. 


\section{PCB Waste Treatment On-Site Alt 7: PCB Solvent Extraction \& Uranium Soil Wash}

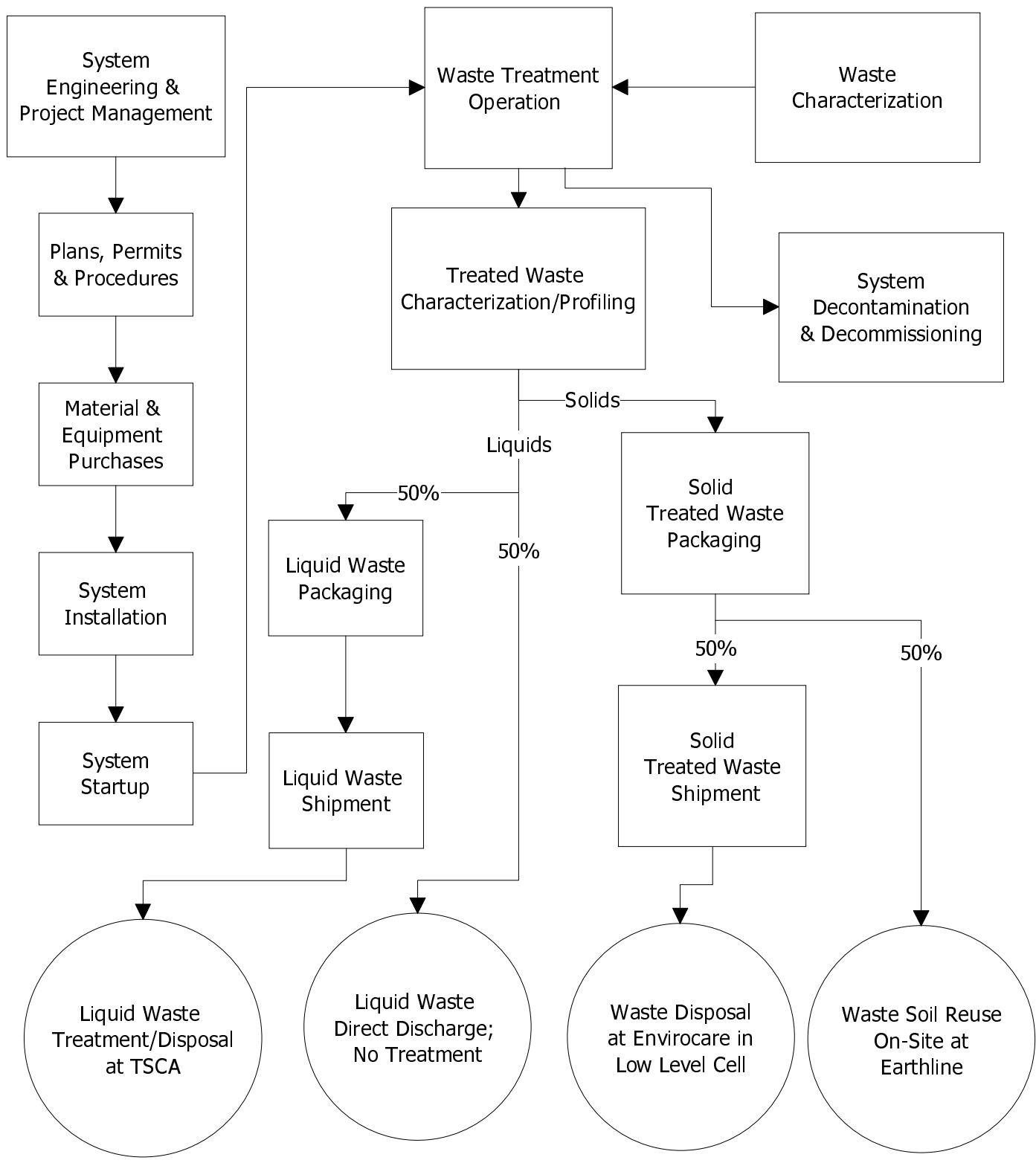

Fig. 4.4. Flow diagram for AEMP Alternative 7: Treatment on-site using solvent extraction and soil wash. 
PCB Waste Storage

Alternative 8: PCB Waste Storage for 5 Years

Followed by Treatment and/or Disposal

Storage Option Cases:

A: On-Site at Earthline Plant 1

B: Off-Site at Earthline Plant 2

C: Off-Site Out of State

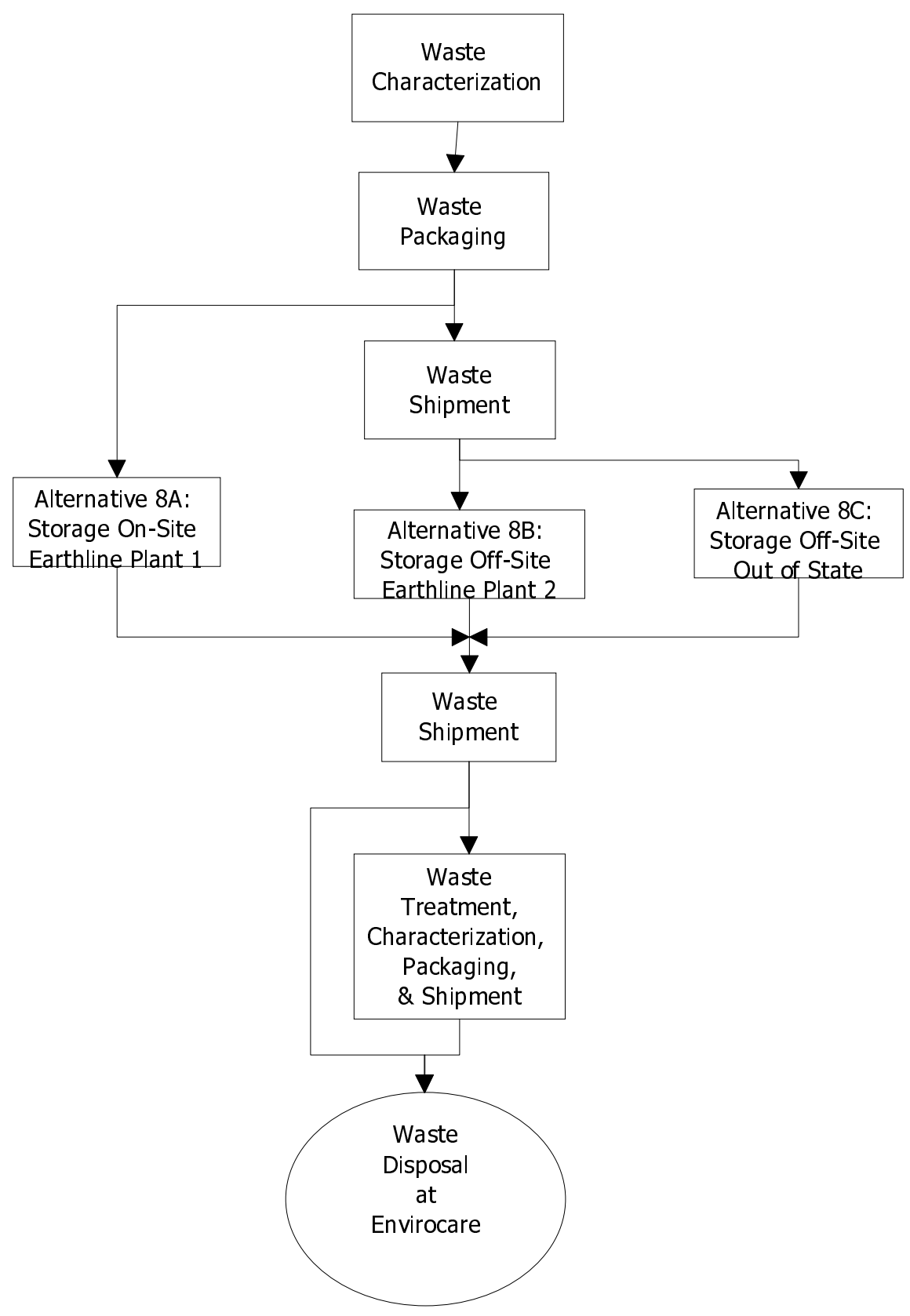

Fig. 4.5. Flow diagram for AEMP Alternatives 8A, B, and C: Waste storage followed by treatment and/or disposal. 


\section{Evaluating the Alternatives}

The alternatives were evaluated on the performance measures stated above. The results are summarized in Fig. 4.6 and Table 4.2. The detailed cost analysis appears in Appendix E. The uncertainty analysis appears in Appendix F.

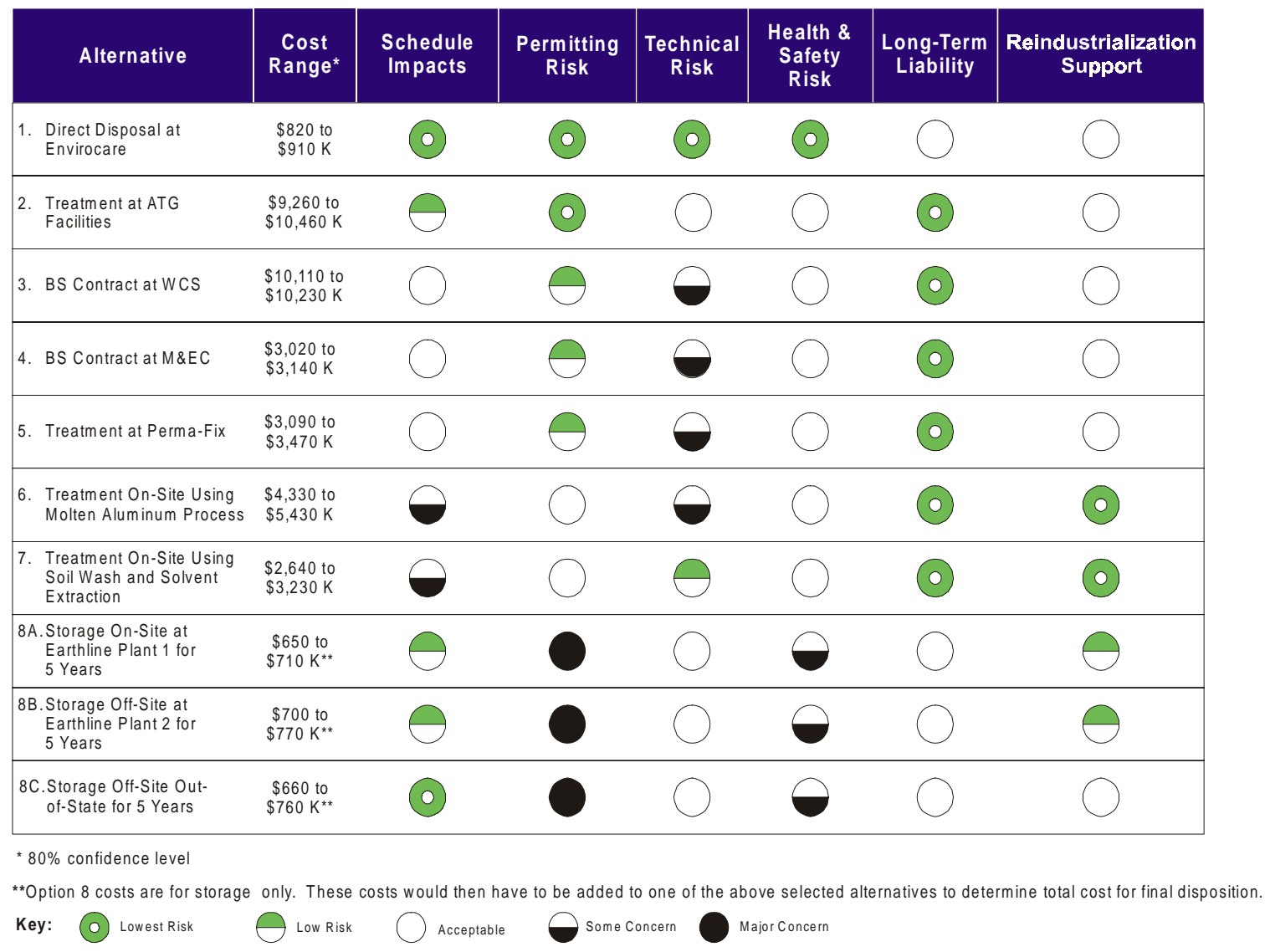

Fig. 4.6. Summary of evaluation of alternatives for AEMP. 
Table 4.2. AEMP decision matrix: PCB treatment and disposal alternatives

\begin{tabular}{|c|c|c|c|c|c|}
\hline Schedule impacts & Permitting risk & Technical risk & S\&H risk & $\begin{array}{l}\text { Long-term } \\
\text { liability }\end{array}$ & $\begin{array}{l}\text { Reindustriali- } \\
\text { zation; other } \\
\text { considerations }\end{array}$ \\
\hline \multicolumn{6}{|l|}{ Alternative 1. Direct disposal at Envirocare $(\$ 820-\$ 910 K)$} \\
\hline $\begin{array}{l}\text { Time needed to obtain regional EPA approval per EPA } \\
\text { megarule 40CFR761: per 761.61a-1 mo.; per } \\
761.61 \mathrm{c}-6 \text { mos.) } \\
\text { Time needed to start shipping: per } 761.61 \mathrm{a}-2-3 \\
\text { mos.; per } 761.61 \mathrm{c}-6-9 \text { mos.) } \\
\text { Best case: Sept } 2000 \\
\text { Worst case: June } 2001 \text { (may need additional sampling } \\
\text { for characterization) }\end{array}$ & $\begin{array}{l}\text { Permitted and } \\
\text { operating; approval } \\
\text { under } 761.61 \mathrm{a} \text { or } \mathrm{c} \text { is } \\
\text { likely }\end{array}$ & $\begin{array}{l}\text { Minimal; no new } \\
\text { technologies } \\
\text { involved }\end{array}$ & $\begin{array}{l}\text { Low; little } \\
\text { physical handling } \\
\text { required }\end{array}$ & $\begin{array}{l}\text { Medium; PCBs will } \\
\text { not be destroyed }\end{array}$ & None \\
\hline \multicolumn{6}{|c|}{ Alternative 2. Treatment using ATG facilities and processes, with final disposal at Envirocare $(\$ 9,260-\$ 10,460 \mathrm{~K})$} \\
\hline $\begin{array}{l}\text { Soil was excavated into intermodals, which must be } \\
\text { repackaged to feed ATG facility; facility has its } \\
\text { permits. Forty percent of ATG's capacity dedicated to } \\
\text { Hanford; can operate at } 6000 \mathrm{~h} \text { per year, or } \\
1 \text { million lb/year. Thus, processing AEMP waste } \\
\text { would require } 2 \text { years (small site overwhelming ATG } \\
\text { Gasvit capacity) } \\
\text { Best case: receive waste, start treatment by Dec. } 2000 \\
\text { Most probable case: receive waste in Dec. } 2000 \\
\text { Worst case: receive waste by June } 2001 \text { (Wash. state } \\
\text { delays shipment of soil to ATG for } \sim 6 \text { mos.) }\end{array}$ & $\begin{array}{l}\text { ATG has RCRA and } \\
\text { TSCA permits and } \\
\text { rad license }\end{array}$ & $\begin{array}{l}\text { Plasma-proven in } \\
\text { pilot scale, no full } \\
\text { scale ops; not a } \\
\text { proven technology on } \\
\text { PCBs in soils, but } \\
\text { process will probably } \\
\text { be successful }\end{array}$ & $\begin{array}{l}\text { Medium; high } \\
\text { temperature, high } \\
\text { electrical use, } \\
\text { more waste } \\
\text { handling }\end{array}$ & $\begin{array}{l}\text { Low; PCBs will be } \\
\text { destroyed; emissions } \\
\text { occur but will be } \\
\text { controlled by Gasvit } \\
\text { off-gas treatment }\end{array}$ & None \\
\hline \multicolumn{6}{|c|}{ Alternative 3. Treatment via the Broad Spectrum Treatment contract at WCS, with final disposal at Envirocare $\mathbf{( \$ 1 0 , 1 1 0 - \$ 1 0 , 2 3 0 K )}$} \\
\hline $\begin{array}{l}\text { Currently permitted to handle non-RCRA PCB debris. } \\
\text { Permits are for general operations with provisions for } \\
\text { specific technologies. WCS is deciding between three } \\
\text { technologies and must get technology in place within } \\
1 \text { year to be competitive } \\
\text { Best case: start receiving waste for treatment by June } \\
2001 \\
\text { Most probable: receive waste by Dec. } 2001 \\
\text { Worst case: large programmatic risk; business may be } \\
\text { lost if waste not being treated by June } 2002\end{array}$ & $\begin{array}{l}\text { Has rad license and } \\
\text { RCRA permit; } \\
\text { specific treatment } \\
\text { permit needed after } \\
\text { technology is } \\
\text { selected }\end{array}$ & $\begin{array}{l}\text { Technology not yet } \\
\text { selected }\end{array}$ & $\begin{array}{l}\text { Medium; chemical } \\
\text { hazards with the } \\
\text { technologies being } \\
\text { considered }\end{array}$ & $\begin{array}{l}\text { Low; PCBs will be } \\
\text { destroyed; some } \\
\text { emissions are } \\
\text { possible, depending } \\
\text { on technology } \\
\text { selected }\end{array}$ & None \\
\hline
\end{tabular}


Table 4.2 (continued)

\begin{tabular}{|c|c|c|c|c|c|}
\hline Schedule impacts & Permitting risk & Technical risk & S\&H risk & $\begin{array}{l}\text { Long-term } \\
\text { liability }\end{array}$ & $\begin{array}{l}\text { Reindustriali- } \\
\text { zation; other } \\
\text { considerations }\end{array}$ \\
\hline \multicolumn{6}{|c|}{ Alternative 4. Treatment using the Broad Spectrum Treatment contract at M\&EC, with final disposal at Envirocare $(\$ 3,020-\$ 3,140 \mathrm{~K})$} \\
\hline $\begin{array}{l}\text { Has RCRA permit and rad license. Needs financial } \\
\text { backing (probable investment by Perma-Fix) } \\
\text { Start receiving waste and start treatment: April } 2001 \\
\text { Fernald's contract will take up initial M\&EC capacity } \\
\text { Best case: April } 2001 \text { or sooner } \\
\text { Most probable: April } 2001 \\
\text { Worst case: Never }\end{array}$ & $\begin{array}{l}\text { Must pass first } \\
\text { article testing; has } \\
\text { RCRA permit and } \\
\text { rad license; TSCA } \\
\text { permit may be } \\
\text { attainable in } 6 \text { mos., } \\
\text { but it has not yet } \\
\text { been requested }\end{array}$ & $\begin{array}{l}\text { Thermal desorption, } \\
\text { followed by direct } \\
\text { chemical oxidation } \\
\text { (DCO) - DCO not } \\
\text { proven on chlori- } \\
\text { nated hydrocarbon } \\
\text { waste; no full-scale } \\
\text { treatment history } \\
\text { Not a proven } \\
\text { technology for PCBs } \\
\text { in soils, but probable } \\
\text { success }\end{array}$ & $\begin{array}{l}\text { Medium; chemical } \\
\text { hazards exist }\end{array}$ & $\begin{array}{l}\text { Low; PCBs will be } \\
\text { destroyed; few } \\
\text { hazardous emissions } \\
\text { will occur }\end{array}$ & None \\
\hline \multicolumn{6}{|c|}{ Alternative 5. Treatment at Perma-Fix’s Florida facility, with disposal at Envirocare $(\$ 3,090-\$ 3,470 \mathrm{~K})$} \\
\hline $\begin{array}{l}\text { Expects to get PCB authorization in } 4 \text { mos.; thus, } \\
8 \text { mos. is best case to have a treatment available (DCO } \\
\text { for destruction after separation) } \\
\text { Earthline contracting time needed, via competitive or } \\
\text { sole-source RFP } \\
\text { Best case: April } 2001 \\
\text { Most probable: April } 2002 \text { (if technology needs } \\
\text { adjustment with a dechlorinization step) } \\
\text { Worst case: Never }\end{array}$ & $\begin{array}{l}\text { Has rad license and } \\
\text { RCRA permit in } \\
\text { Fla., but also needs } \\
\text { TSCA treatment } \\
\text { authorization. } \\
\text { Request not yet } \\
\text { submitted; thus, } \\
6 \text { mos. minimum }\end{array}$ & $\begin{array}{l}\text { Same technology as } \\
\text { M\&EC; not a proven } \\
\text { technology for PCBs } \\
\text { in soils, but process } \\
\text { will probably be } \\
\text { successful }\end{array}$ & $\begin{array}{l}\text { Medium; chemical } \\
\text { hazards exist }\end{array}$ & $\begin{array}{l}\text { Low; PCBs will be } \\
\text { destroyed; few } \\
\text { hazardous emissions } \\
\text { will occur }\end{array}$ & None \\
\hline \multicolumn{6}{|c|}{$\begin{array}{l}\text { Alternative 6. Treatment at AEMP with CITC molten aluminum process, with disposal at Envirocare, assuming permitting } \\
\text { of "mobile" technology }(\$ 4,330-\$ 5,430 \mathrm{~K})\end{array}$} \\
\hline $\begin{array}{l}\text { Needs all permits: get an RD\&D permit submitted to } \\
\text { start up equipment } \\
\text { Best case: April } 2001 \text { (for mobile unit, temporary } \\
\text { authorization) after demonstration of technology } \\
\text { (OEPA will expedite this type of permit). Business } \\
\text { relationship with CITC required } \\
\text { Probable case: June } 2002 \\
\text { Worst case: Never. A permitting impasse is possible }\end{array}$ & $\begin{array}{l}\text { TSCA - R\&D } \\
\text { approval required. } \\
\text { Regional authoriza- } \\
\text { tion for }>500 \text { ppm } \\
\text { PCB; or use a } \\
\text { CERCLA path }\end{array}$ & $\begin{array}{l}\text { Not a proven tech- } \\
\text { nology for PCBs in } \\
\text { soils; however, } \\
\text { process will probably } \\
\text { be successful }\end{array}$ & $\begin{array}{l}\text { Medium; high } \\
\text { temperature and } \\
\text { extra waste } \\
\text { handling }\end{array}$ & $\begin{array}{l}\text { Low; PCBs will be } \\
\text { destroyed; low } \\
\text { emissions }\end{array}$ & $\begin{array}{l}\text { Supports AEMP } \\
\text { reindustrializa- } \\
\text { tion; also may } \\
\text { help ease an } \\
\text { expected } \\
\text { capacity problem } \\
\text { at other treat- } \\
\text { ment facilities }\end{array}$ \\
\hline
\end{tabular}


Table 4.2 (continued)

\begin{tabular}{|c|c|c|c|c|c|}
\hline Schedule impacts & Permitting risk & Technical risk & S\&H risk & $\begin{array}{l}\text { Long-term } \\
\text { liability }\end{array}$ & $\begin{array}{l}\text { Reindustriali- } \\
\text { zation; other } \\
\text { considerations }\end{array}$ \\
\hline \multicolumn{6}{|c|}{$\begin{array}{l}\text { Alternative } 7 \text {. Treatment on-site using solvent extraction and soil washing, with disposal or incineration of materials } \\
\text { depending on characterization }(\$ 2,640-\$ 3,230 \mathrm{~K})\end{array}$} \\
\hline $\begin{array}{l}\text { Needs all permits: get an RD\&D permit submitted to } \\
\text { start up equipment } \\
\text { Best case: April } 2001 \text { (for mobile unit, temporary } \\
\text { authorization) after demonstration of technology } \\
\text { (OEPA will expedite this type of permit) and system } \\
\text { installed for operation ( } 3 \text { ton/hr unit) } \\
\text { Probable case: June } 2002 \\
\text { Worst case: Never. A permitting impasse is possible }\end{array}$ & $\begin{array}{l}\text { TSCA }- \text { R\&D } \\
\text { approval required. } \\
\text { Regional authoriza- } \\
\text { tion for }>500 \text { ppm } \\
\text { PCB; or use a } \\
\text { CERCLA path }\end{array}$ & $\begin{array}{l}\text { Proven technology } \\
\text { for PCBs in soils; } \\
\text { likely success }\end{array}$ & $\begin{array}{l}\text { Medium; chemical } \\
\text { solvent and extra } \\
\text { waste handling }\end{array}$ & $\begin{array}{l}\text { Low; PCBs will be } \\
\text { destroyed; few } \\
\text { emissions concerns }\end{array}$ & $\begin{array}{l}\text { Supports AEMP } \\
\text { reindustrializa- } \\
\text { tion; also may } \\
\text { help ease an } \\
\text { expected } \\
\text { capacity problem } \\
\text { at other treat- } \\
\text { ment facilities }\end{array}$ \\
\hline \multicolumn{6}{|c|}{$\begin{array}{l}\text { Alternative 8. Storage and treatment within additional } 5 \text { years with one of above options (add cost to one of other options above) } \\
\text { A: on-site at Plant } 1(\$ 650-\$ 710 \mathrm{~K}) ; \text { B: off-site at Plant } 2(\$ 700-\$ 770 \mathrm{~K}) ; \mathrm{C} \text { : out of state }(\$ 660-\$ 760 \mathrm{~K})\end{array}$} \\
\hline $\begin{array}{l}\text { Best case: Oct. } 2000 \text { to ship to a storage site } \\
\text { The waiting allows for technologies to become } \\
\text { available and for regulatory environment to improve } \\
\text { Must request } 761.65 . \text { a.1 approval for long-term } \\
\text { storage; must keep written record of attempts to find a } \\
\text { disposal site }\end{array}$ & $\begin{array}{l}\text { Need authorization } \\
\text { per } 40 \text { CFR 761.61c; } \\
\text { need CERCLA } \\
\text { ROD mod; storage } \\
\text { facility is available } \\
\text { A: possible but } \\
\text { needs CERCLA } \\
\text { approval } \\
\text { B: less likely; rad } \\
\text { license has been } \\
\text { applied for at Plant } 2 \\
\text { C: possible but not } \\
\text { probable; other } \\
\text { options are available }\end{array}$ & $\begin{array}{l}\text { Slight additional risk } \\
\text { above treatment risk; } \\
\text { must use additional } \\
\text { technology to store } \\
\text { and monitor }\end{array}$ & $\begin{array}{l}\text { Higher: must be } \\
\text { inspected regular- } \\
\text { ly; additional } \\
\text { transport is } \\
\text { involved, then } \\
\text { must be treated } \\
\text { according to one } \\
\text { of the above } \\
\text { options }\end{array}$ & $\begin{array}{l}\text { Medium; PCBs are } \\
\text { not destroyed during } \\
\text { storage time }\end{array}$ & $\begin{array}{l}\text { Storage in Plant } \\
1 \text { or } 2 \text { : a few } \\
\text { more jobs }\end{array}$ \\
\hline
\end{tabular}




\section{Conclusions for AEMP}

Based on Table 4.2 above, direct disposal of the AEMP PCB low-level waste under the EPA megarule (Alternative 1) is the preferred alternative. This option had the lowest total estimated cost (by a factor of 3 or more), and its accompanying risk was judged to be the lowest of the alternatives evaluated.

The most cost-effective thermal destruction technologies off-site appear to be use of M\&EC in Oak Ridge (Alternative 4) and use of Perma-Fix in Florida (Alternative 5). The costs for use of these facilities appear to be comparable to those considered for on-site use at Ashtabula - that is, treatment with soil washing and solvent extraction (Alternative 7).

The analysis of long-term storage followed by treatment (Alternative 8) showed that the costs for temporary storage for 5 years are only slightly less than the costs for direct disposal. Thus, the analysis suggests that it does not make sense to embark on long-term storage, since the cost for longterm storage is comparable to the cost of the direct disposal option. 


\section{Using the LCA System for FEMP Sludges}

Table 5.1 provides a summary of the Fernald PCB low-level RCRA wastes with PCB contamination of 50-500 ppm. The RCRA contaminants include $\mathrm{Pb}, \mathrm{Cd}$, Ba, and F-listed constituents (TCE).

Table 5.1. Summary of wastes at Fernald

\begin{tabular}{|c|c|c|c|c|c|}
\hline \multirow[b]{2}{*}{ Waste form } & \multicolumn{4}{|c|}{$\begin{array}{c}\text { Amount of waste } \\
\text { (lb) }\end{array}$} & \multirow[b]{2}{*}{$\begin{array}{c}\text { Baseline } \\
\text { disposition }\end{array}$} \\
\hline & $\begin{array}{l}\text { PCB low- } \\
\text { level; non- } \\
\text { RCRA }\end{array}$ & $\begin{array}{c}\text { PCB low-level; } \\
\text { RCRA charac- } \\
\text { teristic; UHC } \\
\text { concern }^{a}\end{array}$ & $\begin{array}{c}\text { PCB low-level; } \\
\text { RCRA-listed; } \\
\text { no UHC } \\
\text { concern }^{a}\end{array}$ & $\begin{array}{l}\text { Low-level } \\
\text { RCRA; non- } \\
\text { PCB }\end{array}$ & \\
\hline Liquid & 358 & 200,000 & 100,000 & & TSCA \\
\hline Sludge & 481 & 29,000 & - & 200,000 & M\&EC \\
\hline Debris & 2,500 & 350,000 & 350,000 & & M\&EC \\
\hline
\end{tabular}

${ }^{a} \mathrm{UHC}=$ underlying hazardous constituents. See Fig. 3.1 for discussion of UHC treatment requirements.

Since sludge is the more pressing problem for disposition for FEMP, the LCA evaluated alternatives for the PCB low-level RCRA sludge (29,000 lb) and the non-PCB low-level RCRA sludge (an additional 200,000 lb).

Nearly all the waste summarized above has been stored in boxes or drums for 5-20 years. All storage has remained unchanged since before August 7, 1998 (the date of EPA's megarule), except that two to three containers were combined into one container and that some of the liquid was decanted. All of the above is classified as remediation waste from sumps and burn pit areas.

\section{Evaluation Criteria for FEMP Sludges}

As with the AEMP analysis, the group used screening criteria to eliminate those alternatives that did not meet the following mandatory requirements:

- Alternatives had to comply with all regulations and thus not pose a significant risk to achieving regulatory approval(s) and necessary permits.

- The technology of the alternative had to be sufficiently mature to meet the site's schedule. Appendix D summarizes the available technologies.

The site-specific objectives for FEMP were to

1. minimize life cycle cost,

2. minimize adverse schedule impacts,

3. minimize permitting risk,

4. minimize technical risk,

5. minimize health and safety impacts, and

6. ensure adequate capacity of treatment facility. 
Measures were developed for each objective in order to estimate how well each of the alternatives achieved the objective. The measures were as follows:

1. Life cycle cost. Performance was measured as the estimated total life cycle cost (to DOE) of the alternative.

2. Schedule impacts. Performance was measured by an estimate of the ability to physically accomplish work to be able to meet the site and project schedule; contract accessibility difficulties were included in this estimate. With FEMP the following considerations applied:

- Storage off-site was considered the fastest way to remove the waste from the site and avoid potential interference with the site D\&D schedule. However, it was judged that this option could not meet the regulatory milestone discussed next; this failure to meet the milestone is addressed under Permitting Risk, below.

- A FEMP milestone with EPA required that the waste be treated or dispositioned by September 30, 2001. Since the meeting, the milestone date has been renegotiated to July 2003.

- Another requirement stipulates that the waste be off-site by 2005; disposal must occur by 2006. Both PCB low-level sludge (29,000 lb) and non-PCB low-level RCRA sludge $(200,000 \mathrm{lb})$ must meet the same deadline.

3. Permitting risk. The estimate of permitting risk was based on the degree of compatibility with regulatory requirements and the likelihood of obtaining permit(s) or avoiding the need for permitting. Long-term storage does not meet the Site Treatment Plan obligations. FEMP would have to renegotiate and would need to convince regulators from both the Ohio and the U.S. EPA of the need for a delay in treatment. Consideration might be given only if development of other technologies is delayed significantly.

4. Technical risk. The estimate of technical risk was based on process maturity, flexibility, robustness, and complexity, and on equipment reliability, operability, and maintainability.

5. Health and safety impacts. The impacts on health and safety were estimated by taking into consideration risks both to workers and to the public.

6. Adequate capacity of treatment facility. Most of the other evaluation factors (e.g., the need for additional treatment after disposal or environmental cleanup in the future, stakeholder concerns, job creation, long-term liability, assurance of funding availability) were considered equal for the alternatives studied. The exception was the capacity of the treatment facility, which was considered an important criterion and was included as a separate column in Table 5.3. The adequacy of facility capacity cannot be truly assessed without a knowledge of all of the waste destined for that facility. Since that information is not available, this assessment was based on the size of the facility.

The objectives and the measures are summarized in Table 5.2.

\section{Alternatives for FEMP Wastes}

Based on the above criteria and information, the following alternatives were developed and evaluated for FEMP wastes:

Alternative 1: Treatment using ATG facilities and processes, with disposal at Envirocare. The flowsheet for this process is the same as for AEMP Alternative 2.

Alternative 2: Treatment using the Broad Spectrum (BS) contract at M\&EC, with disposal at Envirocare. The flowsheet for this process is the same as for AEMP Alternative 4. 
Table 5.2. Summary of performance objectives and measures for FEMP

\begin{tabular}{ll}
\hline \multicolumn{1}{c}{ Objective } & \multicolumn{1}{c}{ Measure } \\
\hline $\begin{array}{l}\text { Minimize cost } \\
\text { Minimize adverse schedule }\end{array}$ & $\begin{array}{l}\text { Total life cycle cost } \\
\text { Estimate of the impact on site/project schedule } \\
\text { Minimize permitting risk }\end{array}$ \\
$\begin{array}{l}\text { Degree of compatibility with regulatory requirements and likelihood of } \\
\text { obtaining permit(s) or avoiding the need for permitting }\end{array}$ \\
$\begin{array}{l}\text { Minimize technical risk } \\
\text { impacts }\end{array}$ & $\begin{array}{l}\text { complexity, and equipment reliability, operability, and maintainability } \\
\text { Risk to workers and the public }\end{array}$ \\
$\begin{array}{l}\text { Ensure adequate capacity of } \\
\text { treatment facility }\end{array}$ & Estimated capacity of treatment facility \\
\hline
\end{tabular}

Alternative 3: Treatment using Perma-Fix facilities and processes, with disposal at Envirocare. The flowsheet for this process is the same as for AEMP Alternative 5.

Alternative 4: Treatment at Fernald provided by a vendor as a service. Potential processes and vendors are the following:

a) solvent extraction (Terra Kleen)

b) thermal desorption (Sepradyne)

For both alternatives, solid waste disposal would be at Envirocare, and liquid waste would be sent to the TCSA Incinerator. The flowsheet for this process is shown in Fig. 5.1.

Alternative 5: Storage off-site and out of state for an additional five years, followed by treatment using any of the above alternatives by 2006. The flowsheet for this process is the same as for AEMP Alternative 8C.

Other possible alternatives were also discussed:

1. Direct disposal at Envirocare or Hanford: Direct disposal under the EPA megarule, 40 CFR 761.61a, is not applicable; the PCBs must be treated as an underlying hazardous constituent since the Fernald waste contains RCRA characteristic constituents.

2. Treatment at the TSCA incinerator and disposal at Envirocare: This alternative was not considered practical because the state of Tennessee gives approval for TSCA Incinerator burns only when other options are not available.

3. Treatment using the Broad Spectrum contract at WCS and disposal at Envirocare: This alternative was not applicable because this waste stream is not within current capabilities of WCS. WCS now handles only non-RCRA PCB debris. 
4. Important considerations for technologies to be brought to the site for on-site treatment:

- Commodore solvated electron process - Commodore has a nationwide permit for its technology but has only a pilot unit and no experience with low-level radioactive constituents. FEMP's schedule will not allow time for the necessary site demonstration.

- No thermal destruction will be allowed on the Fernald site.

- In the past, the thermal desorption used at Fernald was only a drying method at $150^{\circ} \mathrm{F}$. It is uncertain whether thermal desorption would be allowed in the future. 


\section{Fernald PCB Waste Treatment On-Site Alt 4A: Solvent Extraction (Terra Clean) Alt 4B Thermal Desorption (Sepradyne)}

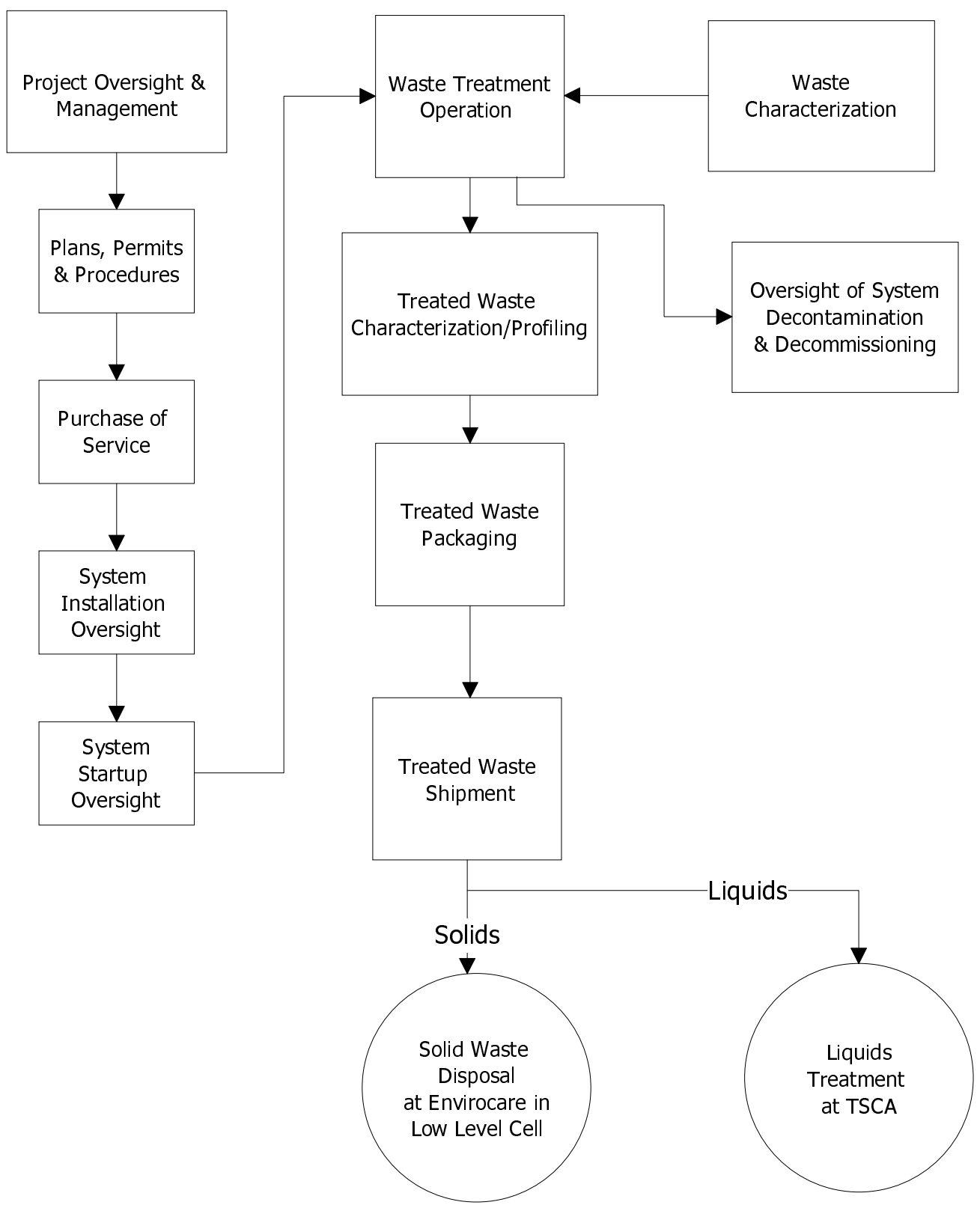

Fig. 5.1. Flow diagram for FEMP Alternatives $4 A$ and 4B: Treatment on-site. 


\section{Evaluating the Alternatives}

The results of the evaluation of the alternatives for FEMP are summarized in Fig. 5.2 and Table 5.3.

\begin{tabular}{|c|c|c|c|c|c|c|}
\hline Alternative & $\begin{array}{l}\text { Cost } \\
\text { Range }^{1}\end{array}$ & $\begin{array}{l}\text { Schedule } \\
\text { Impacts }\end{array}$ & $\begin{array}{l}\text { Permitting } \\
\text { Risk }\end{array}$ & $\begin{array}{l}\text { Technical } \\
\text { Risk }\end{array}$ & $\begin{array}{c}\text { Health \& } \\
\text { Safety Risk }\end{array}$ & $\begin{array}{l}\text { Adequate } \\
\text { Capacity }^{2}\end{array}$ \\
\hline $\begin{array}{l}\text { 1. Treatment at ATG } \\
\text { Facilities }\end{array}$ & $\begin{array}{l}\$ 1,990 \text { to } \\
\$ 2,230 \mathrm{~K}\end{array}$ & & & & & \\
\hline $\begin{array}{l}\text { 2. BS Contract at } \\
\text { M\&EC }\end{array}$ & $\begin{array}{l}\$ 850 \text { to } \\
\$ 940 \mathrm{~K}\end{array}$ & & & & & \\
\hline 3. Treatment at Perma-Fix & $\begin{array}{l}\$ 900 \text { to } \\
\$ 1,000 \mathrm{~K}\end{array}$ & & & & & \\
\hline $\begin{array}{l}\text { 4A. Treatment On-Site } \\
\text { Using Solvent Extraction }\end{array}$ & $\begin{array}{l}\$ 2,930 \text { to } \\
\$ 3,820 \mathrm{~K}\end{array}$ & & & & & \\
\hline $\begin{array}{l}\text { 4B. Treatment On-Site, } \\
\text { Using Thermal Desorption }\end{array}$ & $\begin{array}{c}\$ 3,000 \text { to } \\
\$ 3,850\end{array}$ & & & & & \\
\hline $\begin{array}{l}\text { 5. Storage Off-Site, } \\
\text { Out-of-State for } 5 \text { Years }\end{array}$ & $\begin{array}{l}\$ 290 \text { to } \\
\$ 320 K^{3}\end{array}$ & & & & & \\
\hline
\end{tabular}

${ }^{1} 80 \%$ confidence level

${ }^{2}$ Indication of relative facility capacity to treat or store the waste stream.

${ }^{3}$ Option 5 costs are for storage only. These costs would have to be added to one of the above selected alternatives to determine the total cost for final disposition.

Key:

Lowest Risk

$\bigcirc$ Low Risk $\bigcirc$ Acceptable Some Concern

Major Concern

Fig. 5.2. Summary of evaluation of alternatives for FEMP sludges. 
Table 5.3. FEMP decision matrix: PCB treatment and disposal options

\begin{tabular}{|c|c|c|c|c|}
\hline Schedule impacts (risk) & Permitting risk & $\begin{array}{c}\text { Technical } \\
\text { risk }\end{array}$ & $\begin{array}{c}\text { S\&H } \\
\text { risk }\end{array}$ & Capacity \\
\hline \multicolumn{5}{|c|}{ Alternative 1. Treatment using ATG facilities and processes, with final disposal at Envirocare $(\mathbf{\$ 1 , 9 9 0 - \$ 2 , 2 3 0 K )}$} \\
\hline $\begin{array}{l}\text { Facility has all its permits } \\
40 \% \text { of its capacity ( } 1 \text { million lb/year) will be dedicated to } \\
\text { Hanford; can operate at } 6000 \text { h/year; would take } 1.5 \text { mos. with } \\
\text { Fernald waste } \\
\text { Expected start of operations: Dec. } 2000 \\
\text { Best case: receive waste, start treatment by Dec. } 2000 \text {; could } \\
\text { complete treatment by Sept. } 2001 \\
\text { Probable case: complete treatment by March } 2003 \text { (possible Wash. } \\
\text { state delays in permitting of } ~ 6 \text { mos.; possibly separate } \\
\text { procurement to expedite schedule; shipping waste in drums OK) } \\
\text { Worst case: complete treatment by } 2006\end{array}$ & $\begin{array}{l}\text { Has rad license and } \\
\text { RCRA, TSCA permits }\end{array}$ & $\begin{array}{l}\text { Plasma-proven in } \\
\text { pilot scale, no full- } \\
\text { scale operations; } \\
\text { likely success }\end{array}$ & $\begin{array}{l}\text { Medium: high } \\
\text { temperature; more } \\
\text { electrical use }\end{array}$ & $\begin{array}{l}6000 \mathrm{~h} / \text { year at } 350 \\
\mathrm{lb} / \mathrm{h}=2.1 \text { million } \mathrm{lb} / \\
\text { year }\end{array}$ \\
\hline \multicolumn{5}{|c|}{ Alternative 2. Treatment using Broad Spectrum Treatment contract at M\&EC, with final disposal at Envirocare $(\$ 850-\$ 940 \mathrm{~K})$} \\
\hline $\begin{array}{l}\text { Has RCRA permit and rad license; needs financial backing } \\
\text { (probable investment by Perma-Fix) } \\
\text { Start receiving waste and start treatment: April } 2001 \\
\text { Fernald's contract will take up initial M\&EC capacity; task order in } \\
\text { place through Broad Spectrum Treatment contract } \\
\text { Best case: April } 2001 \text { or sooner to start treatment; complete } \\
\text { treatment by Sept. } 2001 \\
\text { Most probable: accept waste by April 2002; complete treatment by } \\
\text { Sept. } 2002 \\
\text { Worst case: never (if no financial backing found) }\end{array}$ & $\begin{array}{l}\text { Must pass first-article } \\
\text { testing; has RCRA } \\
\text { permit and rad license; } \\
\text { TSCA permit may be } \\
\text { attainable in } 6 \text { mos., but } \\
\text { it has not yet been } \\
\text { requested }\end{array}$ & $\begin{array}{l}\text { Thermal desorption } \\
\text { followed by DCO. } \\
\text { DCO not proven on } \\
\text { chlorinated } \\
\text { hydrocarbon waste; } \\
\text { no full-scale } \\
\text { treatment; likely } \\
\text { success }\end{array}$ & $\begin{array}{l}\text { Low: lower tempera- } \\
\text { ture, pressure; } \\
\text { chemical hazards } \\
\text { being mitigated }\end{array}$ & 1.2 million lb/year \\
\hline
\end{tabular}


Table 5.3 (continued)

\begin{tabular}{|c|c|c|c|c|}
\hline Schedule impacts (risk) & Permitting risk & $\begin{array}{c}\text { Technical } \\
\text { risk }\end{array}$ & $\begin{array}{c}\text { S\&H } \\
\text { risk }\end{array}$ & Capacity \\
\hline \multicolumn{5}{|c|}{ Alternative 3. Treatment using Perma-Fix facilities and processes, with final disposal at Envirocare $(\$ 900-\$ 1,000 \mathrm{~K})$} \\
\hline $\begin{array}{l}\text { Expects to get PCB authorization in } 4 \text { mos.; } 8 \text { mos. best case to } \\
\text { have treatment (DCO for destruction after separation) } \\
\text { Facility in place; has most permits; TSCA storage permit in } 3 \text { mos.; } \\
3,000 \text {-lb/day unit } \\
\text { Fernald contracting time needed, via competitive or sole-source } \\
\text { RFP; M\&EC might subcontract work to Perma-Fix } \\
\text { Best case: receive waste by April 2001; complete treatment by } \\
\text { Sept. } 2001 \\
\text { Most probable: April } 2002 \text { (if technology needs adjustment) } \\
\text { Worst case: Never }\end{array}$ & $\begin{array}{l}\text { Has RCRA permit and } \\
\text { rad license in Fla.; } \\
\text { TSCA treatment } \\
\text { authorization not yet } \\
\text { requested and would } \\
\text { require at least } 6 \text { mos. }\end{array}$ & $\begin{array}{l}\text { Same technology as } \\
\text { at M\&EC; see above } \\
\text { block }\end{array}$ & $\begin{array}{l}\text { Low: lower tempera- } \\
\text { ture, pressure; } \\
\text { chemical hazards } \\
\text { being mitigated }\end{array}$ & $\begin{array}{l}600,000 \mathrm{lb} / \text { year (half } \\
\text { the capacity being } \\
\text { installed at M\&EC) }\end{array}$ \\
\hline \multicolumn{5}{|c|}{$\begin{array}{l}\text { Alternative 4. Treatment at FEMP with mobile technology, with solids disposal at Envirocare and liquids disposal at TSCA Incinerator } \\
\text { A: solvent extraction from Terra Kleen }(\$ 2,930-\$ 3,820 K) \text {; B: thermal desorption from Sepradyne }(\$ 3,000-\$ 3,850 K)\end{array}$} \\
\hline $\begin{array}{l}\text { Requires redirection of current site policy against on-site treatment } \\
\text { Best case: assume contract by April } 2001 \text { (for mobile unit); } \\
\text { installed for operation by Sept. 2001; readiness assessment } \\
\text { operation by early } 2002 \text {; treatment completed by early } 2003 \\
\text { Worst case: Never } \\
\text { Most probable: Dec. } 2003\end{array}$ & $\begin{array}{l}\text { Terra Kleen: rad license } \\
\text { and RCRA permit are } \\
\text { not needed; obtaining } \\
\text { TSCA permit should } \\
\text { not be problem } \\
\text { Sepradyne: has no } \\
\text { TSCA permit at present }\end{array}$ & $\begin{array}{l}\text { Terra Kleen: con- } \\
\text { tracting issue in that } \\
\text { not accepting DOE } \\
\text { contracts; medium } \\
\text { likelihood of solving } \\
\text { Sepradyne: proven } \\
\text { technology }\end{array}$ & $\begin{array}{l}\text { Low: lower tempera- } \\
\text { ture, pressure; } \\
\text { chemical hazards } \\
\text { being mitigated }\end{array}$ & $\begin{array}{l}\text { Terra Kleen: } \\
300,000 \text { lb/year } \\
\text { Sepradyne: Same }\end{array}$ \\
\hline \multicolumn{5}{|c|}{ Alternative 5 . Store off-site and out of state and treat within 5 additional years with one of above technologies $(\$ 290-320 \mathrm{~K})$} \\
\hline $\begin{array}{l}\text { Allows technologies to become available } \\
\text { Allows regulatory environment to change } \\
\text { Request } 40 \text { CFR } 761.65 . \text { a. } 1 \text { approval for long-term storage; must } \\
\text { keep written record of attempting to find disposal site } \\
\text { Best case: Sept. } 2001 \text { to ship to storage site } \\
\text { Probable and worst case: Never }\end{array}$ & $\begin{array}{l}\text { Facility available; } 40 \\
\text { CFR } 761.61 \mathrm{c} \text { approval } \\
\text { required; may be very } \\
\text { high-risk }\end{array}$ & $\begin{array}{l}\text { Slight additional risk } \\
\text { above treatment risk; } \\
\text { must use additional } \\
\text { technology to store } \\
\text { and monitor }\end{array}$ & $\begin{array}{l}\text { Higher: requires } \\
\text { regular inspection, } \\
\text { additional transport, } \\
\text { then treatment per } \\
\text { one of the options } \\
\text { above }\end{array}$ & $\begin{array}{l}\text { Limited space on site, } \\
\text { but much space at } \\
\text { licensed off-site } \\
\text { facilities }\end{array}$ \\
\hline
\end{tabular}




\section{Conclusions for FEMP}

The results of the analysis, summarized in Fig. 5.2, suggest that commercial treatment off-site is the preferred path for disposition of FEMP PCB sludges. None of the three off-site treatment facilities evaluated (ATG, M\&EC, or Perma-Fix) are currently in operation, but they are expected to be in operation by the July 2003 schedule milestone. Based on the current fixed-price Broad Spectrum contract, treatment at M\&EC is the lowest-cost option. Thus, the outcome of this study is validation of FEMP's current plans to treat its PCB sludges at M\&EC.

A second important finding for FEMP is that application of the megarule to the existing inventory of PCB waste streams at FEMP will allow reclassification of much of the waste, thereby producing significant cost savings. Specifically, as of August 1998 (the date the megarule was issued), the megarule allows sites to use as-found PCB concentrations and the average concentration from the full volume of a spill to determine the required course of action. 


\section{Appendices}

A. List of Attendees in Ashtabula, June 19-23, 2000

B. Description of EPA Megarule, Technologies, and PCB Permitting

C. Innovative Regulator Role in Site-Specific PCB Problem Solving

D. Available PCB Treatment Technologies: Summary Table and Technology Fact Sheets

E. Cost Analysis

F. Uncertainty Analysis 


\section{Appendix A - List of Attendees in Ashtabula, June 19-23, 2000}

\begin{tabular}{|c|c|c|c|c|c|}
\hline Participant & June 19 & \begin{tabular}{|l|} 
June 20 \\
\end{tabular} & June 21 & June 22 & June 23 \\
\hline \multicolumn{6}{|l|}{\begin{tabular}{|l|} 
Earthline Technologies \\
\end{tabular}} \\
\hline Jim Henderson & 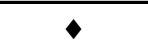 & & & & - \\
\hline Jeff Kulpa & - & & & & \\
\hline Scott Altmayer & 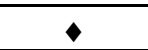 & 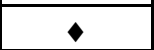 & $\bullet$ & 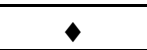 & 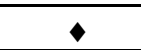 \\
\hline Eric Marsh & $\bullet$ & $\bullet$ & & & \\
\hline Jennifer Williamson & 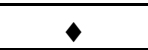 & $\bullet$ & 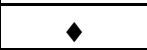 & 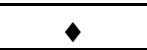 & 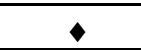 \\
\hline Marian Heffner & 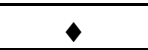 & 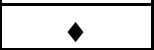 & 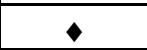 & 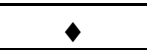 & 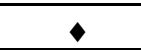 \\
\hline \multicolumn{6}{|l|}{ DOE AEMP } \\
\hline Geoff Gorsuch & 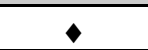 & & & & \\
\hline John Ganz & $\bullet$ & 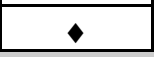 & $\bullet$ & $\bullet$ & $\bullet$ \\
\hline \multicolumn{6}{|l|}{ DOE Ohio and Support } \\
\hline Doug Maynor & $\bullet$ & $\bullet$ & 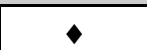 & $\bullet$ & 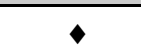 \\
\hline Richard Govers & $\bullet$ & $\bullet$ & $\bullet$ & $\bullet$ & 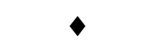 \\
\hline \multicolumn{6}{|l|}{ ORNL } \\
\hline Mike Morris & $\bullet$ & $\bullet$ & $\bullet$ & $\bullet$ & 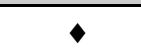 \\
\hline \multicolumn{6}{|l|}{ Mixed Waste Focus Area } \\
\hline David Eaton & 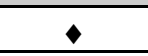 & 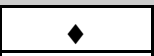 & $\bullet$ & 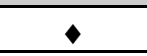 & 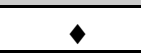 \\
\hline Vince Maio & $\bullet$ & 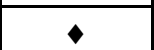 & 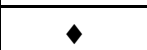 & 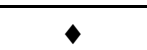 & 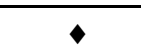 \\
\hline Steve Lopez $^{a}$ & $\bullet$ & 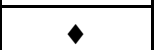 & 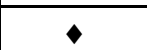 & 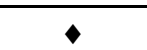 & 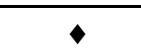 \\
\hline Greg Hulet & & & 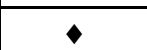 & $\bullet$ & \\
\hline \multicolumn{6}{|l|}{ D\&D Focus Area } \\
\hline Nicholas Hefty, FIU & $\checkmark$ & 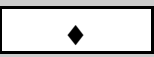 & 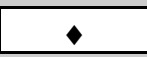 & 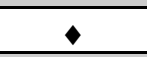 & 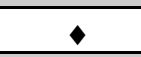 \\
\hline \multicolumn{6}{|l|}{\begin{tabular}{|l|} 
DOE CEMP Support and Battelle \\
\end{tabular}} \\
\hline Jim Griffin & $\bullet$ & $\bullet$ & $\bullet$ & $\bullet$ & $\bullet$ \\
\hline Steve Schmucker & $\bullet$ & $\bullet$ & & & \\
\hline \multicolumn{6}{|l|}{ Fluor Fernald } \\
\hline Dennis Cook & $\bullet$ & 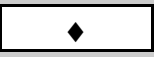 & $\bullet$ & $\bullet$ & \\
\hline \multicolumn{6}{|l|}{ DOE HQ and Support } \\
\hline Beverly Whitehead & $\bullet$ & $\bullet$ & & & \\
\hline Quon Kwan & 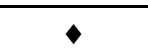 & $\bullet$ & & & \\
\hline Keely Lange & 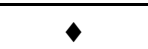 & 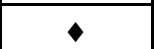 & 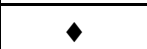 & 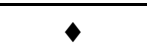 & \\
\hline \multicolumn{6}{|l|}{ US EPA } \\
\hline John Smith & 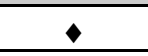 & $\bullet$ & & & \\
\hline Tony Martig & 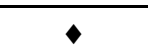 & & & & \\
\hline \multicolumn{6}{|l|}{ Ohio EPA } \\
\hline Adrienne La Favre & $\bullet$ & $\bullet$ & & & \\
\hline \begin{tabular}{|l} 
Total number of participants \\
\end{tabular} & 24 & 20 & 15 & 15 & 13 \\
\hline
\end{tabular}

${ }^{a}$ Environmental Technologies \& Integration 


\title{
Appendix B - Description of EPA Megarule, Technologies, and PCB Permitting
}

\author{
Provided by Nicholas Hefty \\ Florida International University
}

Since the U.S. Environmental Protection Agency (EPA) issued new rules governing the treatment, storage and disposal of PCBs, the term "megarule" has surfaced as the common reference to the amendments of the Toxic Substance Control Act (TSCA). Specific issues and their interpretation remain with the regulations; however, new tools that were previously unavailable to generators have been added. All generators of PCB waste will now have the ability to examine these new rules and make determinations with guidance from regional EPA representatives if necessary, and implement methods and utilize technologies that both satisfy compliance with the regulations and in some instances reduce the financial burdens previously encountered. This appendix provides citations from several sources that are authoritatively representative of some specific issues regarding these new rules, especially regarding the issue of radioactively contaminated PCB waste streams.

The specific topics discussed in this appendix are as follows:

1. information on the EPA megarule;

2. additional information available from EPA web sites;

3. information from the state of Utah regarding management of PCB wastes;

4. links to PCB lists of approved PCB waste handlers and storage facilities;

5. a list of EPA regional PCB permits, approvals, and pending applications;

6. a list of EPA regional PCB points of contact.

\section{Disposal of Polychlorinated Biphenyls (PCBs) - The EPA Final Rule}

EPA amended its rules under the Toxic Substances Control Act (TSCA) that address the manufacture, processing, distribution in commerce, use, cleanup, storage and disposal of polychlorinated biphenyls (PCBs). The rule

- provides flexibility in selecting disposal technologies for PCB wastes by expanding the list of available decontamination procedures;

- provides less burdensome mechanisms for obtaining EPA approval for a variety of activities;

- clarifies and/or modifies certain provisions where implementation questions have arisen;

- modifies the requirements regarding the use and disposal of PCB equipment;

- addresses outstanding issues associated with the notification and manifesting of PCB wastes and changes in the operation of commercial storage facilities;

- codifies policies that EPA has developed and implemented over the past 19 years.

This rule will streamline procedures. It focuses on self-implementing requirements and the elimination of duplication. Some activities currently requiring PCB disposal approvals will no longer require those approvals. EPA believes that this rule will result in substantial cost savings to the regulated community while protecting against unreasonable risk of injury to health and the environment from exposure to PCBs.

What follows is an excerpt from EPA on the TSCA final rules. 


\title{
Final Rule: Amendments to the TSCA PCB Disposal Regulations Including Amendments to the PCB Notification and Manifesting Rule
}

\begin{abstract}
Section 6(e) of the Toxic Substances Control Act (TSCA), 15 U.S.C. 2605, specifically directs EPA to regulate the marking, disposal, manufacturing, processing, distribution in commerce, and use of polychlorinated biphenyls (PCBs). Since 1978, EPA has promulgated numerous rules addressing all aspects of the life cycle of PCBs. On June 10, 1991 (56 FR 26738), EPA published an Advanced Notice of Proposed Rulemaking (ANPRM) to solicit comments on possible changes to the TSCA PCB disposal regulations. More than ninety commenters responded with comments and supporting data on the issues outlined in the ANPRM, a number of other topics pertaining to the PCB regulations and the interaction between those regulations and other Federal and State programs affecting PCBs. EPA chose to consider all of the comments and proposed changes in a number of areas of the PCB regulations in addition to those addressed in the ANPRM. On December 6, 1994 (59 FR 62788), EPA solicited comments on its Notice of Proposed Rulemaking (NPRM) to amend the PCB regulations at 40 CFR Part 761 to: (1) provide flexibility in selecting remediation standards and disposal technologies for certain PCB wastes and to expand the list of prescribed, self-implementing decontamination procedures; (2) provide less burdensome mechanisms for obtaining EPA approval for a variety of activities; (3) clarify and/or modify the regulations where ambiguity may exist; (4) modify the requirements in light of concerns associated with the use/maintenance, distribution in commerce and disposal of PCB equipment, and (5) address outstanding issues associated with the notification and manifesting of PCB wastes and changes in the operation of commercial storage facilities. EPA received almost 5,000 comments from nearly 300 parties on the proposal, resulting in numerous changes to the draft regulations.
\end{abstract}

Roughly 80 issues are addressed by this final rule. Some changes are of a clarifying nature, while others represent a significant departure from the way EPA has handled these issues in the past. The major changes fall into five categories:

- Disposal of "large-volume" wastes. For purposes of disposal, "large-volume" PCB wastes such as remediation wastes and automobile shredder fluff are separated from traditional PCB wastes such as transformers, dielectric fluids, and capacitors. This rule retains the dilution prohibition, but allows the disposal of remediation waste on the basis of risk rather than on the basis of its original PCB concentration. The rule provides flexibility in approving disposal options by establishing decision-making criteria, as opposed to promulgating cleanup numbers or waste management techniques for all situations.

- Decontamination. This rule allows the decontamination, without a PCB disposal approval, of many materials that are contaminated with PCBs.

- Research and development and/or treatability studies. Most small-scale R\&D treatability studies are exempt from permitting; EPA establishes volume and concentration limits with provisions for modification. Under a class exemption, small quantities of PCBs may be manufactured (or imported) by facilities for use in their own PCB disposal research activities. Notification and record-keeping are required.

- Coordinated approval. The rule allows EPA regional administrators to recognize certain federal or state PCB-waste-handling activities as being equivalent in protection to a TSCA PCB storage or disposal approval. Examples could include federally or state-issued hazardous waste treatment, storage, disposal or corrective action permits or permits issued under state TSCA look-alike laws. 
- Notification and Manifesting (N\&M) rule. A number of clarifications or amendments have been made to the PCB N\&M rule. These actions address implementation issues associated with the December 1989 N\&M rule and address legal issues raised by the regulated community.

This final rule is deregulatory in nature. It provides individuals with more flexibility in their PCB disposal practices while continuing to provide protection from unreasonable risk. The rule also allows for enhanced coordination of PCB waste management activities under TSCA with the requirements of other federal or state PCB waste-handling activities. This rule deletes a number of outdated requirements, modifies the regulations to address problems in the applicability or implementation of certain requirements, makes certain policies or regulations consistent with the requirements of other federal statutes, and otherwise makes it easier for the regulated community to comply with the PCB regulations.

Finally, EPA establishes certain authorizations and exemptions that would allow the scientific community to conduct research on PCBs and on PCB-contaminated media for the development of innovative disposal technologies without needing to obtain approval from the agency.

\section{Additional EPA Information}

\section{EPA PCB Home Page}

The EPA PCB home page, located at http://www.epa.gov/opptintr/pcb, includes extensive information, with links to background EPA information, PCB regulations, interpretive guidance, health effects, PCB waste handlers, and other links.

\section{PCB Technologies}

The document entitled Generic Technology Group Descriptions for PCB Mixed Waste contains a comprehensive perspective of various technologies and includes a limited list of various vendors or providers of services for these waste streams. Additional references for technologies utilized for PCB/radioactive waste streams are also available from the EPA "Reach It" web page, http://www. epareachit.org/index $3 . \mathrm{html}$. Some of the technologies listed there are the following:

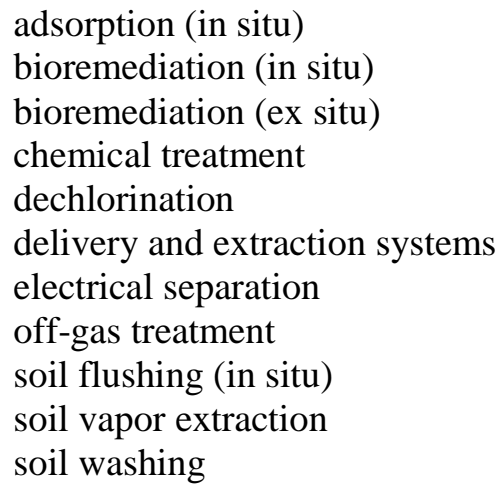

soil washing-hydro-sep solidification and stabilization solvent extraction surfactant flushing thermal desorption thermal desorption-desorption and vapor extraction thermal desorption-indirect system thermally enhanced recovery (in situ) vitrification

\section{Information on PCB Technologies and Additional Data}

Section 5, "Treatment and Disposal Technologies and Associated Cost," of the EPA document Management of Polychlorinated Biphenyls in the United States, online at http://irptc.unep.ch/ pops/indxhtms/cspcb05.html, provides information on various technologies (generic), with supporting data relative to PCB disposal and associated costs. The document does not address the specific issue 
of radioactively contaminated PCB waste streams, nor does it address RCRA or TSCA waste streams. Therefore, the cost data provided cannot accurately represent expected costs for disposal of these specific unique wastes. However, the document provides a through evaluation of current technologies. Additional chapters of the document are also available online from http://irptc.unep.ch/ pops/indxhtms/ pcbtoc.html.

\title{
Comments and Responses during the PCB Amendment Rulemaking
}

EPA regularly solicits comments on pending rulemaking. The following are a few comments and responses that ensued during the PCB amendment rulemaking process. The EPA PCB home page (http://www.epa.gov/opptintr/pcb) provides links to other comments and responses.

\section{Comment 2:}

In order to provide generators of PCB/radioactive waste safe disposal options, EPA should allow radioactive waste disposal facilities authorized under the Atomic Energy Act that meet or exceed the substantive technical standards for municipal or industrial solid waste landfills to accept low risk $\mathrm{PCB} /$ radioactive wastes as alternative to disposal in an industrial or municipal solid waste landfill. These facilities are at least as protective of human health and the environment as state permitted, licensed or registered municipal or solid waste landfills. This disposal option can be accomplished by revising paragraphs \$761.60(b)(ii), \$761.60(b)(ii), \$761.60(b)(6)(iii), \$761.61(a)(5)(i)(B)(1) and $\$ 761.62(b)$ to include an option for PCB/radioactive waste.

\begin{abstract}
Response 2:
The Agency has concerns that disposal practices at those facilities, while appropriate for radioactive waste, may result in am unreasonable risk to human health and the environment from PCBs $\geq 50 \mathrm{ppm}$ disposed of at those sites. Therefore, $\$ \mathbf{7 6 1 . 5 0}(\mathbf{b})(\mathbf{7})$ provides that any person disposing of $\mathrm{PCB} /$ radioactive waste must do so taking into account both its $\mathrm{PCB}$ concentration and its radioactive properties. EPA has, however, added the option of disposing of radioactive PCB remediation waste $<50 \mathrm{ppm}$ in a waste management unit licensed under the Atomic Energy Act. Disposers should be advised that site-specific permit or license conditions or local requirements may preclude such disposal. EPA intends to address radioactive $\mathrm{PCB}$ remediation waste at $\geq 50 \mathrm{ppm}$ PCBs on a case-by-case basis under $\$ 761.61(c)$. Any person disposing of $\mathrm{PCB} /$ radioactive waste at $\geq 50 \mathrm{ppm}$ PCBs must do so taking into account both the PCB concentration and the radioactive properties of the waste. When taking into account only the properties of the PCBs in the waste (and not the radioactive properties of the waste), if the waste meets the requirements for disposal in a facility permitted, licensed, or registered by a state as a municipal or non-municipal nonhazardous waste landfill (e.g., PCB bulk product waste under \$761.62(b)(1)), then the person may dispose of the PCB/radioactive waste, without regard to the PCB component of the waste, on the basis of its radioactive properties in accordance with all applicable requirements for the radioactive component of the waste.
\end{abstract}

\section{Comment 3:}

A commenter stated that EPA is asserting that a variety of PCB wastes can be safely treated by generators without prior approval by EPA and if bearing low PCB concentrations or low PCB leachability, can be disposed at non-TSCA-approved facilities. Since EPA is relaxing the \$761.60(a) disposal standards as extensively as proposed, then $\mathrm{PCB} /$ radioactive wastes and the non-chlorinated organic solvents used to decontaminate them ought to be eligible for disposal at facilities licensed to manage radioactive wastes. This result is especially important in view of the total absence of TSCAapproved facilities presently able to handle PCB/radioactive wastes. EPA is urged to: (i) amend the definition of "PCB remediation waste" and "PCB non-remediation waste" to provide that they include radioactive wastes, (ii) amend the off-site disposal options in \$761.61(a)(5) to allow off-site disposal 
of non-liquid PCB/radioactive remediation wastes with PCBs under $50 \mathrm{ppm}$ at a facility licensed by the NRC or an Agreement State for that sort of radioactive wastes, (iii) amend the off-site disposal options in \$761.62(b)(1) to allow off-site disposal of PCB non-remediation wastes which leach PCBs at less than $50 \mathrm{ppb}$ as measured by the TCLP at a facility licensed by the NRC or an Agreement State for that sort of radioactive waste and (iv) amend the requirements in \$761.79(a)(1) for off-site sale/use of non-chlorinated solvents used for treatment of PCB/radioactive wastes (remediation or non-remediation) or for decontamination of PCB- and radioactive-contaminated surfaces, so that these solvents can be used/disposed by a facility licensed by the NRC or an Agreement State for that sort of radioactive wastes."

\title{
Response 3:
}

EPA has addressed the regulation for disposal of waste containing PCBs and radioactive materials with respect to the PCB content of the waste. EPA emphasizes that additional requirement under other federal, state and local laws may apply to the radioactive content of this waste. PCB radioactive waste having PCB concentrations $<50 \mathrm{ppm}$ is addressed in $\$ 761.50(\mathbf{b})(7)(\mathbf{i i})$ as follows:

\begin{abstract}
Any person disposing of $\mathrm{PCB} /$ radioactive waste must do so taking into account both its PCB concentration and its radioactive properties. If, taking into account only the properties of the PCBs in the waste (and not the radioactive properties of the waste), the waste meets the requirements for disposal in a facility permitted, licensed, or registered by a state as a municipal or non-municipal non-hazardous waste landfill (e.g., PCB bulk product waste under \$761.62(b)(1)), then the person may dispose of the $\mathrm{PCB} /$ radioactive waste, without regard to the $\mathrm{PCB}$ component of the waste, on the basis of its radioactive properties in accordance with all applicable requirements for the radioactive component of the waste.
\end{abstract}

\section{Comment 6:}

A commenter suggested that EPA revise the definition of "PCB remediation waste" and "PCB nonremediation waste" to include radioactive wastes. The commenter also suggested that EPA revise the off-site disposal options in \$761.62(b)(1) to allow off-site disposal of PCB non-remediation wastes which leach PCBs at less than $50 \mathrm{ppb}$ as measured by the TCLP at a facility licensed by the NRC or an Agreement State for PCB/radioactive wastes.

\section{Response 6:}

In the final rule, EPA provides the storage and disposal requirement for $\mathrm{PCB} /$ radioactive waste at $\$ 761.50(b)(7)$.

\section{§761.65(b) - Radioactive Waste \\ Comment 1:}

Nuclear safety standards. The commenters indicate that EPA has set out standards relating to nuclear safety. The standards for nuclear safety should be enforced by the appropriate Agency. Another commenter stated that they believe that $\mathrm{PCB} /$ radioactive waste should only be subject to NRC regulations.

\section{Response 1:}

The regulatory requirements set out in $\mathbf{4 0}$ CFR 761.65 relate to PCBs, not nuclear safety. The problem of PCBs being contaminated with radioactive material was raised by the Department of Energy in connection with their facilities. They indicated that if our storage for disposal requirements were followed for certain types of radioactive waste contaminated with PCBs, a criticality issue could develop. In response to this issue, the Agency is modifying the storage for disposal requirements at \$761.65(b) to allow, for instance, a curb that is less than 6 " in height. The Toxic Substances Control Act states that the term "chemical substance" does not 
include any source material, special nuclear material or byproduct material, as those terms are defined in the Atomic Energy Act and implementing regulations. However, materials such as naturally occurring radioactive, residual, accelerator produced and any material managed (or made) radioactive may not be subject to NRC regulations. Such material can also contain PCBs and may not be regulated by NRC. This final rule has been developed in consultation with the Department of Energy and with the approval of the Nuclear Regulatory Commission.

\section{Comment 3:}

Allowing PCB/fissionable radioactive waste to be placed in non-DOT approved packaging invites unnecessary repackaging of the materials prior to transportation. Such repackaging increases the risk of exposure and release.

\section{Response 3:}

This allowance is necessitated by the physical properties of the waste. Fissionable material must be specially stored in a way that does not promote nuclear chain reactions in the material. Packaging such waste in standard type DOT containers would often cause releases of radiation.

\section{PCB Question and Answer Manuals}

The Question and Answer Manuals prepared by EPA are an easy way to find answers to frequently asked questions regarding PCBs. It should be noted, however, that it is the Code of Federal Regulations that includes the requirements for compliance with TSCA regulations.

The EPA Question and Answer Manuals are available online at

http://www.epa.gov/opptintr/pcb/qapt1a.pdf (vol. 1)

http://www.epa.gov/opptintr/pcb/qapt2b.pdf (vol. 2)

http://www.epa.gov/opptintr/pcb/qapt3.pdf (vol. 3)

Web site addresses are included for the three volumes; these may be used in a search or find mode on keywords to easily extract information germane to specific issues. Below are two questions and answers taken from the 1999 PCB Question and Answer Manual.

Q: Please confirm that $\$ 761.50(\mathrm{~b})(7)$ authorizes the disposal of radioactive, non-liquid PCB wastes into low-level radioactive waste disposal facilities operated under the purview of the Atomic Energy Act (e.g. DOE). Those facilities are not subject to state permitting and licensing and thus do not possess state permits or licenses as described in that paragraph and in $\S 761.61(\mathrm{a})(5)(\mathrm{v})(\mathrm{A})$.

A: Under $\$ 761.50(b)(7)$, as added by the PCB Disposal Amendments (63 FR 35384, June 29, 1998), you may dispose of $\mathrm{PCB} /$ radioactive waste on the basis of its radioactive properties, without regard to the PCB component of the waste, if the PCB disposal rules allow the waste to be disposed of in a facility permitted, licensed, or registered by a State as a municipal or non-municipal non-hazardous waste landfill. The PCB disposal rules allow materials containing PCBs to be disposed of in this type of landfill only if the PCB concentration is low, or the PCBs are not likely to leach from the material. We reasoned that a facility authorized to accept radionuclides would be sited, designed, constructed and operated in such a manner as to attenuate PCBs and keep them from contaminating any underlying aquifer. Therefore, disposal of these low-concentration or non-leaching PCBs in a radioactive waste disposal facility would not present an unreasonable risk of injury to human health or the environment. This should clarify that EPA's concern is not that a particular municipal or non- 
municipal non-hazardous waste landfill be available and permitted to accept the

$\mathrm{PCB} /$ radioactive waste, but rather that the PCB characteristics of the waste are such that they can be managed in a radioactive waste disposal facility.

Q: If bulk product waste is radiologically contaminated, can the waste be disposed of in a landfill used for the disposal of radiologically contaminated waste even though the state does not license, register, or permit landfills used for disposal of these materials?

A: In accordance with $\$ 761.50(\mathrm{~b})(7)(\mathrm{ii})$, any person disposing of $\mathrm{PCB} /$ radioactive waste must do so taking into account both its PCB concentration and its radioactive properties. If, taking into account only the properties of the PCBs in the waste (and not the radioactive properties of the waste), the waste meets the requirements for disposal in a facility permitted, licensed, or registered by a State as a municipal or non-municipal non-hazardous waste landfill (e.g., PCB bulk product waste under Sec. 761.62(b)(1)), then the person may dispose of the $\mathrm{PCB} /$ radioactive waste, without regard to the PCB component of the waste, on the basis of its radioactive properties in accordance with all applicable requirements for the radioactive component of the waste. The facility that accepts the $\mathrm{PCB} /$ radioactive bulk product waste must be operating under a valid permit, but the permit does not have to have been issued by the state.

\section{Envirocare of Utah Management of PCB}

The state of Utah has issued a RCRA Part B Modification to Envirocare of Utah to accept radioactively contaminated $\mathrm{PCB}$ remediation waste and bulk product waste with guidelines specific for managing these waste streams. The section submitted to the state of Utah for modification in regards to the management of waste containing PCBs is available at http://www.eq.state.ut.us/ eqshw/adobe/envirocare/EattII-1-14.pdf

\section{PCB Waste Handlers}

List of approved disposal facilities — http://www.epa.gov/opptintr/pcb/stordisp.html

List of alternate decontamination approvals — http://www.epa.gov/opptintr/pcb/79(h).htm

List of approved storage facilities — http://www.epa.gov/opptintr/pcb/comstor.htm 


\section{U.S. EPA Regional PCB Permits, Approvals, and Pending Applications}

The following material was derived from a telephone survey of the ten EPA regions regarding currently permitted PCB treatment and disposal technologies, research and development activities, and pending permit applications.

\begin{tabular}{|c|c|}
\hline \multicolumn{2}{|c|}{$\begin{array}{l}\text { Legend: } \\
\text { ATD - Alternate thermal destruction; } C D-\text { Chemical dechlorination; } C W L-\text { Chemical waste landfill; } \\
F L B R-\text { Fluorescent light ballast recycling; IN-Incinerator; } M R-P C B \text { electrical cable processing for } \\
\text { metal recovery; } P C D-\text { Pipeline and compressor systems decontamination; } P R-\text { Pipeline removal; } \\
P S-\text { Physical separation; } T D-P C B \text { transformer decommissioning }\end{array}$} \\
\hline \multicolumn{2}{|l|}{$\begin{array}{l}\text { Region } 1 \\
\text { Kim Tisa (617) 918-1527 }\end{array}$} \\
\hline Superior Services Global Recycling & Light ballast \\
\hline Areovox & $\begin{array}{l}\text { Decontamination painted surfaces } \mathrm{CO}_{2} \text { blasting } \\
\text { chemical stripping (site-specific) }\end{array}$ \\
\hline Yankee Atomic & Painted surfaces shot blasting (site-specific) \\
\hline Electric Boat & Painted surfaces shot blasting (site-specific) \\
\hline Anonymous & R\&D bioremediation (pending) \\
\hline Maxymillian Technologies, Inc. & ATD \\
\hline Full Circle, Inc. & FLBR \\
\hline Alguonguin Gas Transmission Co. & PR \\
\hline \multicolumn{2}{|l|}{$\begin{array}{l}\text { Region } 2 \\
\text { John Brogard (Permits) (212) 637-4162 }\end{array}$} \\
\hline Occidental Petroleum & Trial burn permit issued \\
\hline General Electric & $\begin{array}{l}\text { Authorization for in situ treatment thermal desorption } \\
\text { with oxidation of desorbed PCBs - thermal } \\
\text { treatment of vapors }\end{array}$ \\
\hline CECOS International & Landfill permit \\
\hline State University Buffalo NY (SUNY) & R\&D alternative soil washing and bioremediation \\
\hline ConEdison & Bioremediation permit \\
\hline Syracuse University & $\begin{array}{l}\text { R\&D chemical engineering treatment of PCBs } \\
\text { utilizing superheated steam }\end{array}$ \\
\hline Foster Wheeler & $\begin{array}{l}\text { Bench-top treatabilities for soil washing and solvent } \\
\text { extraction }\end{array}$ \\
\hline SUNY & Biological activated carbon water containing PCBs \\
\hline Mercury Refining Co & Separation of PCBs \\
\hline Aluminum Co. of America & Landfill \\
\hline $\begin{array}{l}\text { New Jersey Institute of Technology } \\
\text { Hazardous Substance Research Center }\end{array}$ & $\begin{array}{l}\text { R\&D of microwave-assisted remediation of PCBs in } \\
\text { soil }\end{array}$ \\
\hline NJIT & Chemical extraction technology for removal of PCBs \\
\hline Full Circle Ballast Recyclers & Separation of PCB waste from copper wire \\
\hline EPA Office of R\&D & Disposal of liquid chlorine in mobile incinerator \\
\hline Geoenvironmental Laboratories NJIT & Research permit general technologies \\
\hline SUNY & $\begin{array}{l}\text { R\&D Oswego nonspecific electrochemical, } \\
\text { peroxidation, photocatalytic and biochemical }\end{array}$ \\
\hline Newco Waste Systems & Copper recovery vapor degreasing of PCBs, smelting \\
\hline Brookhaven National Laboratory & High-efficiency boiler \\
\hline
\end{tabular}




\begin{tabular}{|c|c|}
\hline \multicolumn{2}{|c|}{$\begin{array}{l}\text { Legend: } \\
\text { ATD - Alternate thermal destruction; } C D-\text { Chemical dechlorination; } C W L-\text { Chemical waste landfill; } \\
\text { FLBR - Fluorescent light ballast recycling; IN-Incinerator; } M R-P C B \text { electrical cable processing for } \\
\text { metal recovery; } P C D-\text { Pipeline and compressor systems decontamination; } P R-\text { Pipeline removal; } \\
P S-\text { Physical separation; TD - PCB transformer decommissioning }\end{array}$} \\
\hline Hyatt Industries & Capping \\
\hline Berlex Laboratories & Capping \\
\hline Chemical Waste Management & Landfill \\
\hline Occidental Chemical & Incineration \\
\hline Fluor Daniel GTI & $\begin{array}{l}\text { R\&D treatment of soils - chemical oxidation using } \\
\text { ozone }\end{array}$ \\
\hline Adirondack & Research electron beam treatment PCB soil \\
\hline Geovation Technologies & $\begin{array}{l}\text { R\&D anaerobic bioremediation of PCBs in } \\
\text { groundwater }\end{array}$ \\
\hline CWM Chemical Services, LLC & CWL \\
\hline General Electric & PS \\
\hline \multicolumn{2}{|l|}{$\begin{array}{l}\text { Region } 3 \\
\text { Charlene Creamer (215) 814-2145 }\end{array}$} \\
\hline Carnige Mellon & R\&D soil treatment \\
\hline Howard University & R\&D soil technology \\
\hline General Electric & chemical treatment (pending) \\
\hline CNG Transmission Corp. & $\mathrm{PR}$ \\
\hline Columbia Gas Transmission Corp & $\mathrm{PR}$ \\
\hline \multicolumn{2}{|l|}{$\begin{array}{l}\text { Region } 4 \\
\text { Stuart Perry (404) 562-8980 }\end{array}$} \\
\hline Safety-Kleen (PPM) Inc. & $\mathrm{CD}$ \\
\hline Chemical Waste Management & CWL \\
\hline Trans-Cycle Industries & FLBR \\
\hline $\begin{array}{l}\text { Environmental Technologies Unlimited } \\
\text { Corp. }\end{array}$ & PCD \\
\hline Trans-Cycle Industries & PCD \\
\hline Texas Gas Transmission Corp. & PR \\
\hline Transwestern Pipeline Corp. & $\mathrm{PR}$ \\
\hline $\begin{array}{l}\text { Environmental Technology Unlimited } \\
\text { Corp. }\end{array}$ & PS \\
\hline Trans-Cycle Industries & TD \\
\hline Florida International University & R\&D \\
\hline \multicolumn{2}{|l|}{$\begin{array}{l}\text { Region } 5 \\
\text { Tony Martig (312) 353-2291 }\end{array}$} \\
\hline $\begin{array}{l}\text { Commodore Remediation Technologies, } \\
\text { Inc. }\end{array}$ & $\mathrm{CD}$ \\
\hline Sunohio, Inc. & $\mathrm{CD}$ \\
\hline Safety Kleen Oil Recovery Co. & $\mathrm{CD}$ \\
\hline Wayne Disposal Inc. & CWL \\
\hline $\begin{array}{l}\text { Commodore Remediation Technologies, } \\
\text { Inc. }\end{array}$ & PCD \\
\hline Vector Group, Inc. & PCD \\
\hline Natural Gas Pipeline Co. of America & PR \\
\hline
\end{tabular}




\begin{tabular}{|c|c|}
\hline \multicolumn{2}{|c|}{$\begin{array}{l}\text { Legend: } \\
\text { ATD - Alternate thermal destruction; } C D-\text { Chemical dechlorination; } C W L-\text { Chemical waste landfill; } \\
F L B R-\text { Fluorescent light ballast recycling; IN-Incinerator; } M R-P C B \text { electrical cable processing for } \\
\text { metal recovery; } P C D-\text { Pipeline and compressor systems decontamination; } P R-\text { Pipeline removal; } \\
P S-\text { Physical separation; } T D-P C B \text { transformer decommissioning }\end{array}$} \\
\hline $\begin{array}{l}\text { Laidlaw Environmental Services (Tucker), } \\
\text { Inc. }\end{array}$ & TD \\
\hline \multicolumn{2}{|l|}{$\begin{array}{l}\text { Region } 6 \\
\text { Jim Sales (Permits) (214) 665-6796 }\end{array}$} \\
\hline Waste Control Specialists, LLC & CWL \\
\hline Chemical Waste Management & IN \\
\hline Safety-Kleen (Deer Park), Inc. & IN \\
\hline Philip Environmental Services Corp. & PCD \\
\hline Tennessee Gas Pipeline Co. (Tenneco) & $\mathrm{PR}$ \\
\hline Texas Eastern Gas Pipeline Co. & $\mathrm{PR}$ \\
\hline Transcontinental Gas Pipeline Corp. & $\mathrm{PR}$ \\
\hline \multicolumn{2}{|l|}{$\begin{array}{l}\text { Region } 7 \\
\text { James Callier (Permits) (913) 551-7646 }\end{array}$} \\
\hline Safety-Kleen (PPM), Inc. & $\mathrm{CD}$ \\
\hline Safety-Kleen (Coffeyville), Inc. & IN \\
\hline Northern Natural Gas Co. & $\mathrm{PR}$ \\
\hline Safety-Kleen (Coffeyville), Inc. & TD \\
\hline \multicolumn{2}{|l|}{$\begin{array}{l}\text { Region } 8 \\
\text { Francis Tran (303) 312-6036 }\end{array}$} \\
\hline $\begin{array}{l}\text { Safety-Kleen (Lone and Grassy Mountain), } \\
\text { Grayback }\end{array}$ & CWL \\
\hline Safety-Kleen (Aragonite), Inc. & IN \\
\hline H.E.L.P.E.R. & MR \\
\hline \multicolumn{2}{|l|}{$\begin{array}{l}\text { Region } 9 \\
\text { Yosh Tokiwa (415) 744-1118 }\end{array}$} \\
\hline Chemical Waste Management & CWL \\
\hline U.S. Ecology, Inc. & CWL \\
\hline Salesco Systems USA, Inc. & AZ - FLBR \\
\hline Terra-Kleen Response Group, Inc. & PS \\
\hline \multicolumn{2}{|l|}{$\begin{array}{l}\text { Region 10 } \\
\text { Bernie Pribish (206) 553-5293 }\end{array}$} \\
\hline ATG & AT \\
\hline Geosafe Corp. & AT \\
\hline $\begin{array}{l}\text { Chemical Waste Management of the } \\
\text { Northwest }\end{array}$ & CWL \\
\hline Envirosafe Services Inc. of Idaho & CWL \\
\hline
\end{tabular}




\section{U.S. EPA Regional PCB Points of Contact}

\section{Region 1}

CT, MA, ME, NH, RI, VT

$\begin{array}{ll}\text { Kim Tisa } & \text { (617) } 918-1527 \\ \text { Marianne Milette } & \text { (617) } 918-1854 \\ \text { FAX } & \text { (617) } 918-0527\end{array}$

\section{Region 2}

NJ, NY, PR, VI

Dave Greenlaw (732) 906-6817

John Brogard (permits) (212) 637-4162

Ann Finnegan (732) 906-6177

Dan Kraft

(732) 321-6669

Vivian Chin

(732) 906-6179

Dorothy Zoledziowska (732) 906-6811

FAX

(732) 321-6788

Region 3

DE, DC, MD, PA, VA, WV

Charlene Creamer

(215) $814-2145$

Scott Rice

(304) 231-0501

Roberta Riccio

(215) 814-3107

FAX

(215) 814-3114

\section{Region 4}

AL, FL, GA, KY, MS, NC, SC, TN

Stuart Perry

Craig Brown

(404) $562-8980$

(404) $562-8990$

FAX

(404) 562-8972

\section{Region 5}

IL, IN, MI, MN, OH, WI

Tony Martig

(312) 353-2291

John Connell

(312) 886-6832

Priscilla Fonseca

(312) 886-1334

Jean Greensley

(312) 353-1171

(permit writer/geologist)

Steve Johnson

(312) $886-1330$

(permit writer/geologist)

FAX

(312) $353-4788$
Region 6

AR, LA, NM, OK, TX

Lou Roberts

(214) 665-7579

Jim Sales (Permits)

(214) 665-6796

FAX

(214) 665-7446

\section{Region 7}

IA, KS, MO, NE

Dave Phillippi $\quad$ (913) 551-7395

Gene Evans (Permits) (913) 551-7731

James Callier (Permits) (913) 551-7646

FAX

(913) 551-7065

\section{Region 8}

$\mathrm{CO}, \mathrm{MT}, \mathrm{ND}, \mathrm{SD}, \mathrm{UT}, \mathrm{WY}$

Dan Bench

(303) 312-6027

Francis Tran

(303) 312-6036

FAX

(303) 312-6044

Kim Le (enforcement) (303) 312-6973

FAX

(303) 312-6409

\section{Region 9}

AZ, CA, HI, NV, AS, GU

Max Weintraub

(415) 744-1129

Christopher Rollins

(415) 744-1130

Yosh Tokiwa

(415) 744-1118

FAX

(415) 744-1073

\section{Region 10}

AK, ID, OR, WA

Dan Duncan

(206) 553-6693

Cathy Massimino

(206) 553-4153

Bernie Pribish

(206) 553-5293

FAX

(206) 553-8509

\section{Headquarters}

Washington, DC

Staff

(202) 260-3933 
For reference, the following web site is germane to the DOE Ashtabula Facility site and the relationship the cleanup activities have to the ongoing Superfund cleanup activities.

NPL Site Fields Brook Ohio EPA ID\# OHD980614572

http://www.epa.gov/R5Super/npl/ohio/OHD980614572.htm 
Appendix C - Innovative Regulator Role in Site-Specific PCB Problem Solving 

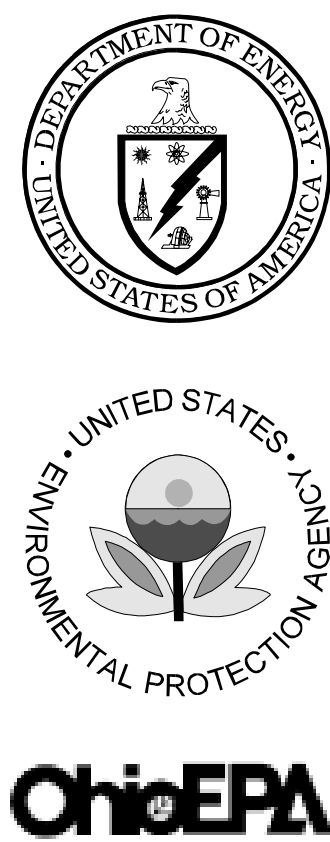

\section{Environmental Compllance Consultation: Innovative Regulator Role in Site-Specific PCB Problem Solving}

Office of Environmental Policy and Guidance, RCRA/CERCLA Division (EH-413)

September 2000

\section{Background}

Ashtabula, Ohio is the site of a former RMI Plant that processed and extruded uranium. Although this site is the smallest of the five Ohio sites for which the U.S. Department of Energy (DOE) has remediation responsibility, it has been chosen as the site to evaluate how to treat polychlorinated biphenyls (PCBs) for the five sites. There is a clear driver from the regulatory oversight agencies for DOE to close this site by the year 2006. The Nuclear Regulatory Commission, U.S. Environmental Protection Agency (U.S. EPA), Ohio Department of Health, and Ohio Environmental Protection Agency (Ohio EPA) all share regulatory oversight for the remediation.

A meeting of experts in remediation technology, cost analysis, mixed waste, and environmental management was convened at Ashtabula, Ohio during June 19-23, 2000, to address the problem of site remediation and waste disposal with respect to PCBs. What was innovative about the meeting was the invited participation of the regulators in addition to the usual experts. Regulators from the Ohio EPA, U.S. EPA Region V, and U.S. EPA Headquarters were present. Particularly noteworthy was the inclusion of one of the authors of the PCB Disposal Amendments [see 63 FR 35384 of June 29, 1998] from U.S. EPA Headquarters, whose participation was sponsored and coordinated by DOE's Office Environmental Policy and Guidance (EH-413).

This meeting is the first time that an environmental regulator at the national level participated proactively in an advisory role during a meeting of decision makers on site remediation. This meeting markedly differs from the norm of (1) asking regulators to react to decisions that have already been made and (2) seeing regulators as adversaries in the clean-up process. This Environmental Compliance Consultation discusses the innovation of early regulator participation, at the national and local levels, in the site remediation decision making process, and how it has enlightened, if not transformed, that process. The following discussion has several parts: The PCB Problem, Understanding the Regulations, Problem Solving, and Conclusion.

\section{The PCB Problem}

The PCB Problem at the Ashtabula, Ohio site can be broken down into several discrete issues or concerns:

Of primary concern in the remediation are four waste streams in which PCBs are present < 500 ppm:

- 12,500 cubic feet of soil contaminated with PCB, Technetium-99 $\left(\mathrm{TC}^{99}\right)$, and uranium.

- 180 cubic feet of floor stripper contaminated with PCBs, $\mathrm{T}^{99}$, and uranium.

- 16 cubic feet of solids contaminated with floor stripper, $\mathrm{PCBs}, \mathrm{Tc}^{99}$, and uranium.

- 8 cubic feet of light ballasts contaminated with PCBs, $\mathrm{TC}^{99}$, and uranium.

Next of concern is the proposal by the on-site contractor to use molten aluminum (instead of the original plasma arc) technology to destroy the PCBs in the wastes as a costeffective alternative. The residual radioactive components would be stabilized and then placed into a low-level waste landfill.

Also of concern is the impact of three key U.S. EPA regulations:

- Recently promulgated PCB Disposal Amendments under the Toxic Substances Control Act (TSCA),

- Recently promulgated Land Disposal Restrictions (LDR) Phase IV Rule under the Resource Conservation and Recovery Act (RCRA) that requires treatment of PCBs as an underlying hazardous constituent in wastes exhibiting the Toxicity Characteristic for metals (including hazardous soil) and allows alternative treatment standards for hazardous soil [see 63 FR 28556 of May 26, 1998], and

- Recently proposed deferral of the LDR requirement under RCRA to treat PCBs as an underlying hazardous constituent in soils exhibiting the Toxicity Characteristic for metals [see 65 FR 7809 of February 16, 2000].

Last but not least is the concern about the definition and implications of the state moratorium on "incineration" in Ohio. 


\section{Understanding the Regulations}

The most critical key to solving the PCB problem is an understanding of the regulations because the primary objective at the Ashtabula site is remediation and waste disposal in compliance with the environmental regulations. Cost-effectiveness is secondary to regulatory compliance. Schedule milestones for regulatory compliance are enforceable while cost-effectiveness is not.

Because of the unfamiliarity of the decision makers with the major provisions of the recently promulgated PCB Disposal Amendments, an author of the regulations from U.S. EPA Headquarters was asked to present an overview at the meeting. The overview highlighted the provisions that were pertinent to the Ashtabula, Ohio PCB wastestreams: disposal of PCB remediation waste [40 CFR 761.61], disposal of PCB bulk product waste [40 CFR 761.62], and disposal of $\mathrm{PCB} /$ radioactive waste [40 CFR 761.50(b)(7)]. [No attempt will be made to summarize those provisions here because they are covered in the guidance booklet, Storage and Disposal of Polychlorinated Biphenyl Waste, DOE-EH-413-9914, and in the EH-413 regulatory bulletin, PCB Disposal Amendments: Final Rule both available at the EH-413 web site [http://www.eh.doe.gov/oepa]. Notwithstanding, the most important provisions that the decision makers learned are as follows:

- PCB remediation waste is basically nonliquid media on which PCBs were spilled or released.

- The Anti-Dilution Rule does not apply to PCB remediation waste. In other words, such waste may be disposed at its asfound concentration.

- Radioactive waste, including radioactively contaminated soil, containing PCBs $<50$ ppm, may be placed into a radioactive landfill without regard to the PCBs.

- Radioactive waste, including radioactively contaminated soil, containing PCBs $>50$ ppm may be placed into a RCRA mixed waste landfill or a TSCA chemical waste/radioactive landfill.

- PCB bulk product waste, which is essentially discarded material manufactured with non-liquid PCBs, does not have to be disposed by incineration or placement in a TSCA chemical waste landfill; it may be disposed in certain types of solid waste landfills depending on the leaching rate of the non-liquid PCBs.
Furthermore, a representative from U.S. EPA Region $\mathrm{V}$ was asked to present an overview of the TSCA approval process. His overview highlighted the approval process for storage, disposal, and decontamination of PCB waste. It was clear that the molten aluminum technology proposed by the on-site contractor would have to receive approval from U.S. EPA as an alternative (to incineration) destruction method under 40 CFR 761.60(e) before it could be deployed. The most important criteria for receiving approval are demonstration of a destruction and removal efficiency of $99.9999 \%$ and no unreasonable risk. This technology has met these requirements for other waste.

The representative from Ohio EPA preferred to answer a set of questions prepared ahead of the meeting instead of making a presentation. She indicated that Ohio EPA does not regulate PCBs. However, Ohio EPA regulates all incinerators. Although Ohio EPA will not adopt the "Boilers and Industrial Furnaces (BIF) Rules" [see 56 FR 7137] until March 2002, she considers the molten aluminum technology proposed to destroy PCBs as a form of incineration. Consequently, the molten alloy (also plasma arc) technology is subject to the moratorium on all commercial hazardous waste incinerators in Ohio (an exception will be discussed later under "Problem Solving"). The moratorium also prohibits treatment of off-site waste. The moratorium was imposed because the State of Ohio believes it has sufficient capacity for incineration and does not want to add any more capacity. However, if the moratorium were lifted, the molten aluminum technology would have to meet the performance standards of 40 CFR Part 264, Subpart O (not Subpart X). Upon meeting the performance standards, Ohio EPA would forward the permit modification (Class 3B) for the molten aluminum technology to the Ohio State Hazardous Waste Facilities Board for final approval.

With respect to the regulation of PCBs as underlying hazardous constituents in wastes exhibiting the Toxicity Characteristic for metals under RCRA LDR Phase IV, Ohio EPA has not adopted the alternative treatment standards for hazardous soil. However, it will use enforcement discretion to allow these standards to be used until their adoption in early Fall 2000.

With respect to the proposed rulemaking by U.S. EPA to defer the LDR requirement under RCRA to treat PCBs as an underlying hazardous constituent in soils exhibiting the Toxicity Characteristic for metals, Ohio EPA has not taken a position. 
While PCBs as an underlying hazardous constituent is not an issue for the contaminated soils at the Ashtabula site, it is a relevant issue at the other DOE sites in Ohio.

\section{Problem Solving}

Following the presentations by the regulators, it was clear to the decision makers at the meeting that they had to go through a structured process to determine how to comply with the regulations. Hence, there was a need to establish a regulatory plan for each waste stream. The first part of any such plan is to categorize each waste stream. Once categorized, the range of general disposal options can be determined. When there is more than one disposal option available, then other factors, such as costs, scheduling, liability, risks, and approvals, can be used to select the desired disposal option.

\section{Categorization}

In pursuit of a regulatory plan for each waste stream, the decision makers were prompted first to categorize each of the four PCB waste streams present at the Ashtabula site. While data are given that PCBs are $<500 \mathrm{ppm}$, it was also assumed that PCBs are $>50 \mathrm{ppm}$. With the help of the regulators, the following categories were determined:

- The 12,500 cubic feet of PCB-Tc ${ }^{99}$-uranium-contaminated soil are a PCB/ radioactive waste. Because soil does not naturally contain PCBs, the PCBs may be presumed to have been spilled or released to the soil. Therefore, it is also a bulk PCB remediation waste.

- The180 cubic feet of PCB-TC ${ }^{99}$-uraniumcontaminated floor stripper contain methylene chloride, which is a F002 listed solvent, and consists of two phases. It is a PCB/radioactive waste. Because the floor stripper was not produced containing PCBs, the PCBs may be presumed to have been released to the floor and collected in the stripper solvent. Therefore, it is also a liquid PCB remediation waste.

- The 16 cubic feet of PCB-TC ${ }^{99}$-uraniumcontaminated floor-stripper solids contain F002 and D008 listed hazardous constituents and are a PCB/radioactive waste. Because the floor stripper was not produced containing PCBs, the PCBs may be presumed to have been released to the floor and collected in the solids separated from the stripper solvent. Therefore, it is also a bulk PCB remediation waste.

- The 8 cubic feet of PCB-Tc ${ }^{99}$-uraniumcontaminated light ballasts are a PCB/ radioactive waste. For purposes of disposal, they are also defined as РСB Items at 40 CFR 761.50(b)(2). The capacitors in the ballasts must be disposed as PCB Articles governed by 40 CFR $761.60(\mathrm{~b})(2)$. If the potting material in the ballasts contains $>50$ ppm PCBs, the material must be disposed as PCB bulk product waste in accordance with 40 CFR 761.62.

\section{General Disposal Options}

The category of a PCB waste stream delimits the range of general disposal options that are available for that waste stream. For example, liquids with PCBs are generally prohibited from landfills. There was remarkable progress in developing a cooperative spirit towards problem solution. The range of general disposal options were arrived at as follows:

- The regulations for disposal of bulk PCB remediation waste allow the $\mathrm{PCB}, \mathrm{TC}^{99}$, and uranium contaminated soil to be landfilled or treated.

- If landfilled, the landfill would have to be a mixed waste landfill (i.e., both a RCRA hazardous waste and low-level radioactive waste landfill) [40 CFR 761.50(b)(7)(ii) and 761.61(a)(5)(i)(B)(2)(iii)]. Whereas previously, only a landfill qualifying as both a TSCA chemical waste and a low-level waste landfill was allowed for this type of waste, the PCB Disposal Amendments expanded the provision to add mixed waste landfills. Notification of the landfill, U.S. EPA, and the state would be required [40 CFR 761.61(a)(3) and 761.61(a)(5)(i)(B)(2)(iv)]. Available landfill options are shown in the figure on the next page.

- If treated, the treatment, namely, the proposed molten aluminum technology would have to receive a PCB disposal approval for an alternative destruction method [40 CFR 761.60(e)] from U.S. EPA and a permit modification or temporary authorization from Ohio EPA (provided the moratorium on incinerators was lifted). The representative from U.S. EPA Headquarters, in the spirit of cooperation, pointed out that to save time and paperwork, there is only one treatment process for bulk PCB remediation waste that does not require an approval - soil washing [40 CFR 761.61(a)(5)(i)(A)]. In the same spirit 


\section{Non-Liquid PCB/Radioactive Waste Landfill Disposal Diagram}

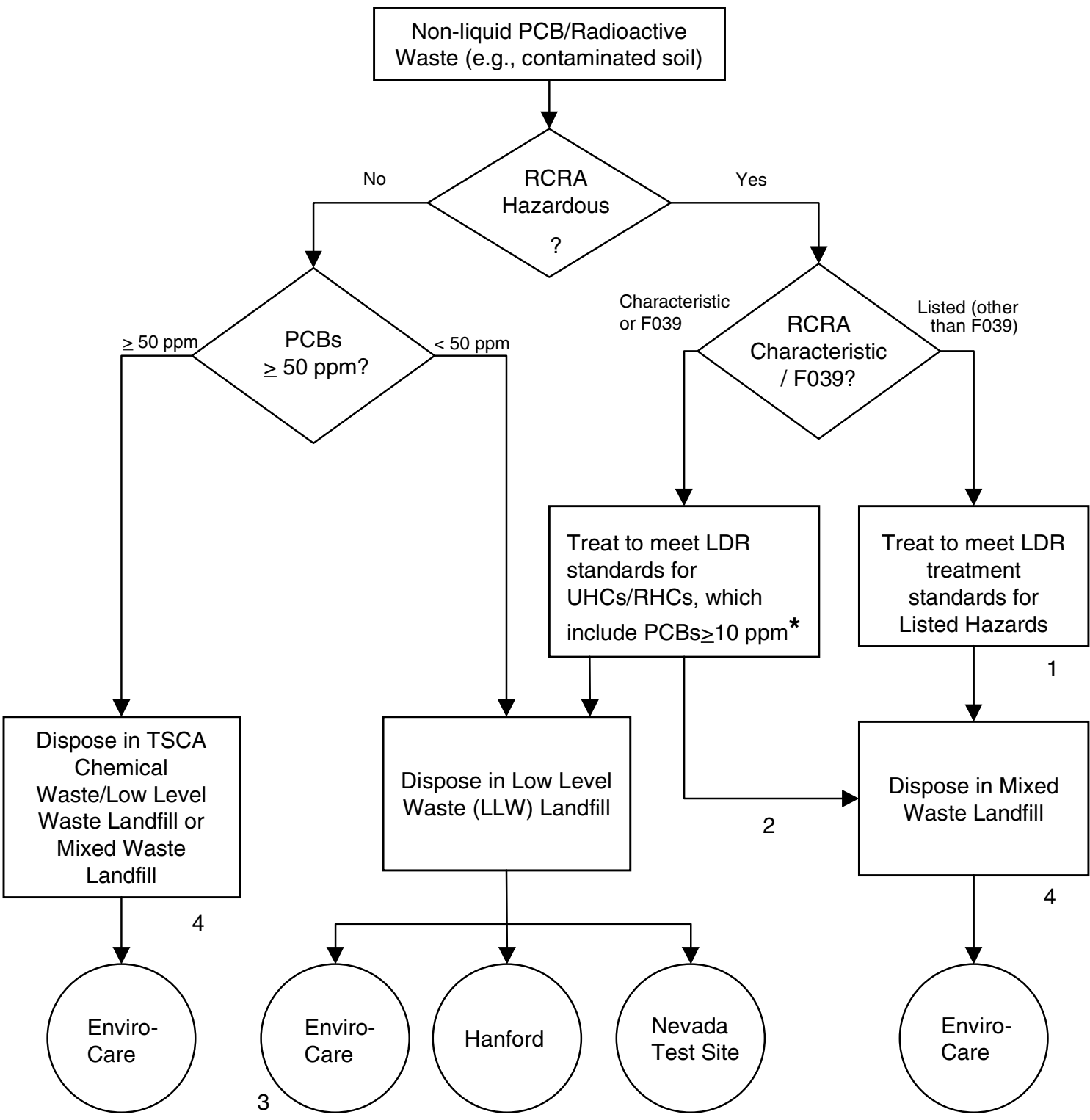

RHC = Regulated Hazardous Constituent (40 CFR 268.40)

UHC = Underlying Hazardous Constituent [40 CFR 268.2(i)]

UTS = Universal Treatment Standard (40 CFR 268.48)

1 Assuming the state has not adopted the alternative LDR treatment standards for contaminated soil (40 CFR 268.49). If state has adopted these standards, then hazardous constituents concentrations must be reduced by $90 \%$ with treatment capped at 10 times UTS [40 CFR 268.49(c)]. For nonwastewater PCBs, this translates into a cap of 100 $\mathrm{mg} / \mathrm{kg}^{3}$ total PCBs concentration. Note: EPA has proposed to exempt toxicity characteristic metal contaminated soil from the requirement to treat $P C B$ s as UHCs.

2 Assuming F039 waste stream. Also, this becomes the pathway if the state has adopted the alternative treatment standards for contaminated soil (40 CFR 268.49) and the treatment results in PCBs $\geq 50$ ppm or a hazardous constituent that is above the TCLP level.

3 Envirocare may not accept decharacterized (formerly RCRA characteristic) waste for disposal in a low level waste landfill pursuant to the terms of its state of Utah permit.

4 NTS and Hanford sites have PCB-mixed waste disposal capability for their own wastes. Steps are being taken to allow use of these facilities by other sites within several years. 
of cooperation, the representative from Ohio EPA pointed out that in spite of the moratorium on incinerators, the State of Ohio was amenable to mobile incinerators. In fact, Ohio EPA would do whatever it could to expedite a "temporary authorization" for a mobile incinerator. Consequently, the molten aluminum technology proposed by the on-site contractor for treating the PCBs in the soil is a realistic option if the technology is designated as a mobile unit. Ten viable off-the-shelf and near-term technologies, including a mobile molten aluminum unit, are available for treatment of the PCBs.

- The regulations for disposal of liquid PCB remediation waste require that the $\mathrm{PCB}$, $\mathrm{TC}^{99}$-uranium-contaminated floor-stripper liquid be decontaminated [40 CFR 761.79] or combusted [40 CFR 761.60(a) or (e)]. The contaminated floor-stripper liquid could be disposed by combustion in the TSCA (also RCRA-permitted) incinerator at Oak Ridge, which is also capable of destroying the F002 organic hazardous constituent as well as handling the lowlevel radioactive constituents. The contaminated floor-stripper solvent could be combusted by proposed molten aluminum technology if it receives a PCB disposal approval for an alternative destruction method [40 CFR 761.60(e)] from U.S. EPA and either a permit modification (provided the incinerator moratorium was lifted) or a "temporary authorization" for a mobile incinerator from Ohio EPA.

- The regulations for disposal of bulk PCB remediation waste allow the $\mathrm{PCB}-\mathrm{TC}^{99}$ uranium-contaminated floor-stripper solids to be landfilled or treated. The range of disposal options is the same as for the contaminated soil except that soil washing is not available as a pre-approved option for extracting the PCBs from the floor-stripper solids. However, some form of washing or chemical extractions may be used with a PCB disposal approval from EPA.

- The regulations for disposal of fluorescent light ballasts consist of those dealing with disposal of PCB/radioactive waste [40 CFR 761.50(b)(7)], disposal of small capacitors [40 CFR 761.60(b)(2)], and disposal of PCB bulk product waste [40 CFR 761.62]. The PCBs in the light ballasts need to be fully characterized in order to determine the appropriate disposal option because the options available depend on whether the:

- Capacitor is intact and non-leaking,

- Potting material has > 50 ppm PCBs, and

- Leaching rate of PCBs $>50 \mathrm{ppm}$ in the potting material is $>10 \mu \mathrm{g}$ of PCBs / L.

\section{Life-cycle Cost Analysis}

The decision makers determined that they would focus on the PCB waste stream of 12,500 cubic feet of contaminated soil. Because of the numerous landfill and treatment options available, they agreed to narrow down these options to eight alternatives. These eight alternatives would then be subject to a life-cycle cost analysis. The analysis would evaluate each alternative with respect to the following:

- Costs

- Schedule impacts

- Permitting risk

- Environment, safety, and health risk

- Long-term liability

- Impact on workforce, reuse of equipment, and reindustrialization

The outcome of the analysis would be a comparison of the alternatives. The outcome and some guidance for interpreting the comparison would be provided to the decision makers for their use in selecting the alternative to be used at the Ashtabula site. It is beyond the scope of this Environmental Compliance Consultation to delve into the details of that life-cycle cost analysis; however, more information can be obtained from the Center for Life Cycle Analysis at (865) 241-2290 and Mixed Waste Focus Group at (208) 526-7002.

\section{Conclusion}

The success of the Ashtabula, Ohio effort can be attributed to many novel factors. A factor of paramount importance was bringing in the regulators, both at the national and local levels, early in the process to participate in a meeting of decision makers on site remediation. This innovation allows the regulators to play a proactive, advisory role. This new role contrasts with the typical perception of regulators as adversaries in the process. The decision makers benefitted from the participation of the regulators from learning first-hand the impact of the regulations on site remediation. They especially 
appreciated being able to ask questions directly of the regulators and to receive straight answers without "going through channels."

The decision makers were fascinated by the fact that the PCB Disposal Amendments resulted in more relaxed requirements, allowing for more options and greater flexibility. The Amendments contrast with the past rulemakings - a pattern of one after another of more stringent, burdensome, and costly regulations. The decision makers would not have appreciated the cost savings provided by the PCB Disposal Amendments if the author of the regulations had not presented an overview of the Amendments. For example, one meeting participant learned that he could dispose of contaminated soil at the as-found concentration of PCBs - not at the concentration of PCBs in the original source.

Perhaps, what impressed the decision makers the most about the participation of the regulators was what happened on the second day of the meeting. The impression was captured by the succinct remark, "Even the regulators were suggesting solutions!"
When placed in a proactive advisory role, regulators clearly contributed to problem solving in ways that were effective and productive. In addition, the interaction between the regulators at the national and local levels was also interesting. The initiative taken by the author of the regulations from U.S. EPA Headquarters in suggesting a way to save time and paperwork helped ease the way for local regulators in making similar suggestions.

Questions of policy or questions requiring policy decisions will not be addressed in EH-413

Environmental Compliance Consultations unless that policy has already been established through appropriate documentation. Please refer any questions concerning the material covered herein to Beverly Whitehead, EH-413, (202) 586-6073.

U.S. Department of Energy

Reisa Kall (EH-413)

1000 Independence Ave., S.W.

Washington, DC 20585

Official Business

ADDRESS CORRECTION REQUESTED 


\section{Appendix D - Available PCB Treatment Technologies: Summary Table and Technology Fact Sheets}

This appendix provides a table summarizing available PCB treatment technologies and fact sheets describing six treatment technologies in greater depth.

Summary Table: Vendors, Technologies, Status, and Permits

\begin{tabular}{|c|c|c|c|c|c|c|c|}
\hline \multirow[b]{2}{*}{ Vendor } & \multirow[b]{2}{*}{ Technology $^{a}$} & \multicolumn{3}{|c|}{ Status } & \multicolumn{3}{|c|}{ Permits } \\
\hline & & $\begin{array}{l}\text { Existing } \\
\text { facility }\end{array}$ & $\begin{array}{c}\text { Proposed } \\
\text { facility }\end{array}$ & $\begin{array}{c}\text { Technology } \\
\text { only }\end{array}$ & RCRA & TSCA & RAD \\
\hline ATG & AT & $x$ & & & $x$ & $x$ & $x$ \\
\hline Clean & AT & & & $x$ & $x$ & & \\
\hline Commodore & $\mathrm{CD}$ & M & & $x$ & & $x$ & \\
\hline CWM & TD & & $x$ & & & & \\
\hline Delphi DETOX & $\mathrm{ABO}$ & M & & $x$ & & & \\
\hline DSSI & HEB & $x$ & & & $x$ & & $x$ \\
\hline EET & SE & M & & $x$ & & & \\
\hline Envirocare & LF & $x$ & & & $x$ & & $x$ \\
\hline GTS & $\mathrm{AT}$ & & $x$ & & & $\mathrm{~S}$ & $x$ \\
\hline Hanford & LF & $x$ & & & $x$ & $x$ & $x$ \\
\hline IT & TD & & & $x$ & & & \\
\hline $\mathrm{M} \& \mathrm{EC}$ & $\mathrm{DCO}$ & & $x$ & & & & \\
\hline NTS & $\mathrm{LF}$ & & $x$ & & $x$ & & $x$ \\
\hline $\begin{array}{l}\text { Oak Ridge } \\
\text { Incinerator }\end{array}$ & IN & $x$ & & & $x$ & $x$ & $x$ \\
\hline Perma-Fix & DCO & & $x$ & & $x$ & & $x$ \\
\hline Sepradyne & TD & & & $x$ & & & \\
\hline Soil Technology & $\mathrm{CD} / \mathrm{SW}$ & M & & $x$ & & & \\
\hline Terra-Kleen & $\mathrm{SW} / \mathrm{SE}$ & M & & $x$ & & $x$ & \\
\hline Thermatrix-EEL & TD & & & $x$ & & & \\
\hline WCS & $\mathrm{LF}$ & $x$ & & & $x$ & $x$ & $x$ \\
\hline Westinghouse & SW & M & & $x$ & & & \\
\hline
\end{tabular}

Source: Information provided by Nicholas Hefty, Florida International University, Miami, Florida.

Abbreviations: $\mathrm{M}$ - Mobile; S - Storage permit only.

${ }^{a} \mathrm{ABO}$ - aqueous based oxidation; AT - alternative thermal; CD - chemical destruction; DCO - direct chemical oxidation; HEB - high-efficiency boiler; IN - incineration; LF - landfill; SE - solvent extraction; SW - soil washing; TD - thermal desorption. 


\title{
Technology Fact Sheets
}

\author{
Prepared by Vince Maio and Greg Hulet (Mixed Waste Focus Area) \\ and Steve Lopez (Environmental Technologies \& Integration)
}

The following pages provide technology fact sheets for six technologies that represent alternatives for the treatment and/or disposal of DOE-Ohio PCB waste.

1. the GASVIT process (ATG)

2. macroencapsulation (ATG)

3. direct chemical oxidation (ATG)

4. macroencapsulation (Envirocare)

5. direct chemical oxidation (Perma-Fix and M\&EC)

6. organic treatment (WCS) 


\section{Technology: GASVIT Process (ATG)}

Class: Hybrid Plasma/Vitrification Process

Maturity (for PCB Mixed Waste): Fully developed for PCB MW and MW requiring organic destruction. Deployable system installed and planned to be operational in December 2000

Vendor: ATG Inc., Richland WA

Contacts: Fred Feizollahi, P.E. 509-375-5160

Related Web Information: http://www.atgusa.com/mixwaste.htm, http://www.inentec.com/iet.asp?Page='technology'\&Section=2 http://www.bechteljacobs.com/broadspectrum/vendor3.htm

\section{Technology Area}

Technology Description. ATG has a RCRA/TSCA permit to treat applicable mixed waste in a plasma enhanced electric-arc melter that was developed and manufactured by Integrated Environmental Technologies, LLC, in part with the support of DOE's Mixed Waste Focus Area. The GASVIT process should be ready for full-scale treatment operations by December of 2000 and will be housed at ATG's commercial complex near Hanford. Washington regulators and the EPA have recognized the GASVIT process as an acceptable treatment for those mixed wastes requiring incineration (e.g., PCB liquids). To address both the organic and inorganic components existing in the PCB mixed waste, the GASVIT hybrid melter-plasma process combines gasification and vitrification into one process. Off-gases from the GASVIT unit will be treated by a high-temperature filter, two scrubbers, a high-efficiency mist eliminator, carbon filters, HEPA filters, a quencher and a syn gas converter. Particulate collected by the high-temperature filter and possibly by other filters will be collected for in-house ATG stabilization.

Specific Throughputs. The GASVIT hybrid melter-arc system is designed to handle solid, liquid, soil, or debris wastes containing PCBs at a range of flow rates up to their permitted level of 1500 metric tons (MT) per year. Designed solid waste throughput is $\sim 500 \mathrm{lb} / \mathrm{h}$, and the liquid waste throughput is $\sim 250 \mathrm{lbs} / \mathrm{h}$. However, The permit lists a maximum design throughput for the GASVIT unit at $350 \mathrm{lb} / \mathrm{h}(0.175 \mathrm{~T} / \mathrm{h})$, and the detailed design specifications list the feed conveyor system with a capacity of $1500 \mathrm{ft}^{3} / \mathrm{h}$. The permit limits total annual time for operation of the GASVIT unit to $6000 \mathrm{~h}$. The final form of the waste exiting the GASVIT hybrid-melter system will be a low-volume, durable, vitrified glass. Volume reduction ratios will be dependent on the type of waste treated, its organic and inorganic content, and the amount of glass frit required to ensure adequate glass formation. Ratios can range from 100:1 to 2:1.

Off-gas Parameters. Average off-gas flow will be $\sim 100-200$ dry scfm and 100-280 scfm with moisture. It will consist of mostly water, nitrogen, and carbon dioxide; but some hydrogen and carbon monoxide is possible. Hydrogen chloride, hydrogen sulfide, and oxides of nitrogen will be present in the 0.1 to $6 \%$ range. Particulate will be $\sim 0.1-3 \mathrm{~g} / \mathrm{SCF}$. The off-gas system of the GASVIT unit will consist of a syn gas converter, such as one supplied by Thermatrix, which should oxidize all remaining organics and thus prevent dioxin and furan formation. Before their release, the off-gases will be monitored for hydrogen chloride, particulate matter, combustible gases, oxygen, hydrogen sulfide and carbon monoxide, as well as sampled for radionuclides, including tritium.

\section{Waste Acceptance}

The GASVIT process has been designed to accept any liquid, solid, sludge, and debris mixed waste that contains any organics, including PCBs, as long as the waste meets ATG's waste acceptance criteria (including limits of its radioactive materials license). The detailed design specifications list 
the following waste media: wood, paper, plastic, metals, gravel, soil sand, filter cake, and semi-dry sludges.

The GASVIT process does not accept any explosive wastes, shock sensitive material, gas cylinders or containers, mixed waste batteries containing lead or cadmium, wastes containing greater than $260 \mathrm{ppm}$ mercury, or reactive wastes that will detonate, or explosively decompose. ATG accepts all waste forms in lab packs, pails, or drums. Liquids can be received in intermediate bulk containers, and debris and solids are accepted in B-25 boxes and cargo vans. Mixed waste destined for the hybrid melter will require removal from its waste package and potential sizing to meet technical feed requirements.

\section{Permitting and Regulatory}

The ATG facility as a whole (i.e., including all technologies, such as GASVIT, macroencapsulation, stabilization, and chemical reduction) is permitted to treat and store RCRA/TSCA mixed waste up to its capacity, which is a volume/mass of 233,000 gal/year, or 9500 metric tons/year (9.5 million kg, or $\sim 21$ million lb/year). However, the permit individually limits the GASVIT plasma-hybrid unit to treating only 3.3 million $\mathrm{lb}$ of waste per year. For comparison, the GASVIT unit could not treat all of the PCB containing mixed waste in the DOE Ohio Field Office in one year, since its mass is nearly 5 million $\mathrm{lb}$.

The assumption is that RCRA-listed as well as RCRA-characteristic mixed waste can be treated at the ATG Hanford facility. However, even though these wastes will be treated to be LDR-compliant, final disposal must still be in a subtitle D mixed waste location, since the waste will not exit RCRA.

\section{Schedule, Cost, and Other Logistics}

ATG is associated with other companies, especially suppliers of waste treatment technologies, such as the GASVIT unit. ATG purchased the GASVIT unit from Integrated Environmental technologies. ATG also operates and owns Allied Nuclear Services, which does commercial low-level-only waste treatment and management at its Bear Creek, Tennessee; Hanford; and Fremont facilities. ATG is part of the Broad Spectrum Contract for PCB liquid mixed wastes only.

Use of the Oak Ridge Broad Spectrum contract's pricing estimator on its web site, http://www. bechteljacobs.com/broadspectrum/prices.htm, provided approximate costs for the treatment of PCB mixed waste liquids via ATG. Even though a particular technology was not specified, this estimator gave treatment costs between $\$ 4.40$ and $\$ 4.80 / \mathrm{lb}$ for PCB-contaminated mixed waste oils, liquids, and acceptable sludges. For dilute aqueous liquids with $\mathrm{PCBs}$, the estimator provided the much lower cost of less than $\$ 0.50 / \mathrm{lb}$. Overall, the estimator gave a cost of nearly $\$ 43,000$ for treating all of the DOE Ohio Field Office $(\mathrm{OH}) \mathrm{PCB}$-contaminated mixed waste liquids.

Limited contact with Hanford personnel in regard to Hanford's existing contact with ATG to treat mixed waste specifically with the GASVIT unit resulted in little cost information. The Hanford contract was established so that general overhead and set-up costs to ATG on an annual basis were covered with the first $120 \mathrm{~m}^{3}$ of mixed waste. Therefore, the treatment cost for this initial volume $\left(\$ 18,000 / \mathrm{m}^{3}\right)$ is considerably more than the treatment cost for those mixed waste inventories received after the initial volume $\left(\$ 2,000 / \mathrm{m}^{3}\right)$. 


\section{Technology: Macroencapsulation (ATG)}

Class: Stabilization

Maturity (for PCB Mixed Waste): Developed for applicable MW debris. Fully deployable system, operational since December 1999

Vendor: ATG Inc., Richland WA 00352

Contact: Fred Feizollahi, P.E. 509-375-5160

Related Web Information: http://www.atgusa.com/mixwaste.htm

\section{Technology Area}

Technology Description. ATG is currently operating a macroencapsulating process for debris mixed waste since nonthermal operations started in late FY 1999. More than likely it consists of simply jacketing the material in a polyethylene container, B-25 box, or drum. The ATG macroencapsulation process is not like the thermoplastic extrusion method performed at Envirocare.

Specific Throughputs. The process is specifically for debris wastes, since RCRA allows only mixed debris to be disposed on land through untested macro encapsulation. Disposal is still, however, in a subtitle $\mathrm{C}$ mixed waste location since the mixed waste will not exit RCRA.

Off-gas Parameters. Since the process is performed without reactions between waste and encapsulant, as well as at room temperature, a macroencapsulation process will generate no off-gas and therefore neither dioxins or furans.

\section{Waste Acceptance}

Macroencapsulation is selectively applicable to solid mixed waste classified as debris (i.e., waste debris greater than $8 \mathrm{~mm}$ in size). It is not appropriate for reactives, liquids, soils, sludges, and/or particulate wastes.

\section{Permitting and Regulatory}

The assumption is that RCRA-listed and RCRA-characteristic mixed waste can be treated at the ATG Hanford facility. However, even though these wastes will be treated to be LDR-compliant, final disposal must still be in a subtitle $\mathrm{C}$ mixed waste location, since the waste will not exit RCRA. Therefore, only Envirocare of Utah or possibly the Hanford disposal site could be utilized.

\section{Schedule, Cost, and Other Logistics}

ATG is associated with other companies, especially suppliers of waste treatment technologies, such as the GASVIT unit. ATG purchased the GASVIT unit from Integrated Environmental Technologies.

Hanford has established a contract with ATG for the treatment of mixed waste streams, and the contract includes treatment via macroencapsulation as well as with the other ATG available (e.g., GASVIT) and potentially available technologies (e.g., MSO). To avoid added procurement delays that are inherent with a competitive call for ATG-like treatment, other owners of waste may be able to add on to the existing Hanford contract.

Based on limited contact with Hanford personnel in regard to its existing contact with ATG to treat mixed waste specifically though macroencapsulation, a contract-established pricing of $\$ 2,000 / \mathrm{m}^{3}$ was provided. 


\section{Technology: Direct Chemical Oxidation (ATG)}

Class: Aqueous based low temperature oxidation

Maturity (for PCB Mixed Waste): Claimed to be fully developed for PCB mixed-waste liquids. Expected to be operational in 3 to 4 years.

Vendor: ATG Inc., Richland WA 99352

Contact: Fred Feizollahi, P.E. 509-375-5160

\section{Technology Area}

Technology Description. Even though the unit is not yet installed, ATG is planning to include an aqueous-based chemical oxidation unit in its suite of existing technologies because its existing RCRA/TSCA permit allows it to perform the chemical oxidation. Like the GASVIT and MSO technologies, the chosen method would be capable of treating PCB containing mixed waste as well as providing equivalent incineration treatment for the hazardous organics. In these aqueous-based oxidation processes, the organic portion of the transuranic or mixed waste is oxidized to water, carbon dioxide, and/or mineral salts via chemical processes in an aqueous solution, which generate little or no off-gas and occur at temperatures nearly an order of magnitude lower than those of combustion. However, reaction and residence times for organic destruction are considerably longer than for combustion (hours to days). Chemical redox methods normally involve the use of oxidizing agents in bath-type reactors. During the oxidation process the organics are oxidized and the oxidizing agent is reduced; thus, the process is usually equipped with methods to regenerate the oxidizing agent to minimize secondary waste. Several of these aqueous-based processes are in development or are being deployed for the treatment of organic/PCB liquids or organically contaminated mixed waste solids or sludges, including peroxydisulfate oxidation (DCO), nitric/phosphoric acid based oxidation, ferricchloride/hydrochloric acid based oxidation $\left(\right.$ DETOX $\left.^{\mathrm{SM}}\right)$, and mediated electrochemical oxidation (MEO).

\section{Schedule, Cost, and Other Logistics}

ATG is associated with other companies, especially suppliers of waste treatment technologies, such as the GASVIT unit. ATG purchased the GASVIT unit from Integrated Environmental Technologies. The MSO technology is being developed for deployment through licensing and partnerships with LLNL. ATG also operates and owns Allied Nuclear Services, which does commercial low-level-only waste treatment and management at its Bear Creek, Tennessee; Hanford; and Fremont facilities. ATG currently holds the Oak Ridge Broad Spectrum L contract for liquid mixed waste only.

Not aware of any contracts outside of the existing Hanford-ATG contract. However, based on limited discussions with Hanford personnel, most of the contract waste will be treated by the GASVIT or macroencapsulation process. No mention was made of the potential DCO process.

Use of the Oak Ridge Broad Spectrum contract's pricing estimator on its web site, http://www. bechteljacobs.com/broadspectrum/prices.htm, provided approximate costs for the treatment of PCB mixed waste liquids via ATG. Even though a particular technology was not specified (e.g., GASVIT, $\mathrm{DCO}$, or MSO) this estimator gave treatment costs between $\$ 4.40$ and $\$ 4.80 / \mathrm{lb}$ for PCB-contaminated mixed waste oils, liquids, and acceptable sludges. For dilute aqueous liquids with PCBs, the estimator provided the much lower cost of less than $\$ 0.50 / \mathrm{lb}$. Overall the estimator gave a cost of nearly $\$ 43,000$ for treating all of the OH PCB contaminated mixed waste liquids. Estimated costs include pretreatment, treatment, and disposal. However, transportation costs from the waste site to the ATG facility were not part of the estimation. 


\section{Technology: Macroencapsulation (Envirocare)}

Class: Stabilization under the Debris Rule

Maturity (for PCB Mixed Waste): Currently operational for RCRA waste under the debris rule

Vendor: Envirocare of Utah Inc., Salt Lake City, UT

Contacts: K. Loveland, A. Drum, 801-532,1330

Related Web Information: http://www.envirocareutah.com

\section{Technology Area}

Technology Description. The Envirocare macroencapsulation process is based on the use of the thermoplastic polymer, low-density polyethylene (LDPE). Hardened solid chips of LDPE are melted and extracted from an extrusion process. The molten polymer is then poured over the waste to provide a barrier coat. This jacketed waste form can then be disposed of on land without analyzing for or collecting leachability or other performance data, so long as the waste is classified RCRA-acceptable debris or lead.

Specific Throughputs. The Envirocare macroencapsulation process is applicable to RCRA-defined debris and lead. The process is specifically for debris wastes, since RCRA allows only mixed debris to be land-disposed through untested macroencapsulation. Disposal is still, however, in a subtitle C mixed-waste location, since the mixed waste will not exit RCRA. With the exception of Envirocareemployee-generated PPE and empty waste containers, no secondary waste is produced by macroencapsulation technologies

Off-gas Parameters. Since macroencapsulation is performed without reactions between waste and encapsulant, as well as at room temperature, the process will generate no off-gas and therefore neither dioxins or furans.

\section{Waste Acceptance}

Macroencapsulation is selectively applicable for solid mixed waste classified as debris (i.e., waste debris $>8 \mathrm{~mm}$ in size). It is not appropriate for reactives, liquids, soils, sludges, and/or particulate wastes. 


\section{Technology: Direct Chemical Oxidation (Perma-Fix / M\&EC)}

Class: Aqueous-based oxidation process

Maturity (for PCB Mixed Waste): Developed for PCB mixed waste with possible deployment through either direct contracting or with the Broad Spectrum Treatment contract

Vendor: Perma-Fix as a part of the Materials and Energy Corporation (M\&EC) Broad Spectrum

Treatment contract.

Contacts: Tim Kimball, Perma-Fix of New Mexico, 505-898-2440; Tom Yarbrough, Perma-Fix of Florida, 800-365-6066; and Chuck Estes of the Oak Ridge Broad Spectrum Contract, 865-576-0127

Related Web Information: http://www.bechteljacobs.com/broadspectrum/vendor1.htm

http://www.llnl.gov/IPandC/op96/03/3o-dir.html

http://ost.em.doe.gov/ifd/mwfa/itsrs/itsr109/itsr109.pdf

http://www.perma-fix.com/processes/process2.html,

http://www.perma-fix.com/florida/fla_mix.html

\section{Technology Area}

Technology Description. Through its subcontractor, Perma-Fix, M\&EC will be providing a direct chemical oxidation (DCO) method for the Oak Ridge broad spectrum treatment of PCB and RCRA mixed waste solids. Use of the Perma-Fix DCO method through direct contracting is also available as an option. Known as the PermaFix II process, the method will usually consist of two stages: separation of organic materials from the waste using thermal desorption or a wet process followed by DCO. In addition to the broad spectrum DCO system under construction at the East Tennessee Technology Park (ETTP), Perma-Fix operates a DCO unit at its Gainesville, Florida, facility. The expected throughput of the Florida facility is $\sim 3000 \mathrm{lb} /$ day; that of the Tennessee facility is twice as much.

The PermaFix II/ DCO technology is an aqueous-based, ambient-pressure nonthermal technology capable of treating nearly all organics. The process uses solutions of sodium or ammonium peroxydisulfate to mineralize organic material to carbon dioxide and water. The expended oxidant (sodium or ammonium hydrogen sulfate) may be regenerated by electrolysis to minimize secondary waste or oxidant cost.

The peroxydisulfate DCO process is an application of a well-established industrial technology. Acidified ammonium peroxydisulfate is one of the strongest oxidants known. It is comparable to ozone and exceeded in oxidative power only by fluorine and oxyfluorides. The process is primarily being developed for the treatment of organic liquids and solids contaminated with organic liquids. It will oxidize the organic fraction of sludge if the matrix is finely divided and slurried with the working solution. Destruction of some organic solids - such as paper, cloth, and styrene resins - is possible, and other plastics and inorganic debris will be partially oxidized and decontaminated. The oxidation potential of peroxydisulfate is high enough to oxidize nearly all organics; thus, the process is virtually "omnivorous." However, perfluorinated polymers (e.g., Teflon) are inert, and reactions with polyethylene and PVC are slow, so surface oxidation to decontaminate rather than destroy the matrix is a more practical goal. Many organics are oxidized by the process at ambient pressure and temperatures in the 80 to $100^{\circ} \mathrm{C}$ range. More recalcitrant materials (e.g., PVC polymers) benefit from higher temperatures $\left(140-180^{\circ} \mathrm{C}\right.$ for $\left.24 \mathrm{~h}\right)$ to partially pyrolize the material before oxidation by peroxydisulfate.

At room temperature, solid peroxydisulfate salts and moderately concentrated solutions are stable. The ion is thermally activated at moderate temperatures $\left(>80^{\circ} \mathrm{C}\right)$ to produce the sulfate radical anion, which is a strong charge transfer agent. This free radical initiates a cascade of oxidation reactions in the organic wastes, producing intermediate organic molecular fragments, organic and hydroxyl free radicals, inorganic ions in high oxidation states [e.g., $\mathrm{Ag}$ (II) and Co (III) if these elements are 
present], and secondary oxidants such as peroxymonosulfate, hydrogen peroxide, ozone, and nascent oxygen.

\section{Schedule, Cost, and Other Logistics}

PCB authorization has been received at the facility, but no PCB treatment has occurred as of yet. There is currently no backlog of waste to be treated. Perma-Fix is the subcontractor bringing the DCO process (PermaFix II) to the Oak Ridge Broad Spectrum Contract.

Use of the Oak Ridge Broad Spectrum contract's pricing estimator on the Bechtel-Jacobs web site (http://www.bechteljacobs.com/broadspectrum/prices.htm) provided approximate costs for the treatment of PCB/RCRA mixed waste solids via M\&EC. Even though a particular technology was not specified (e.g., probably the PermaFix II DCO), this estimator gave treatment costs of $\$ 2.30 / \mathrm{lb}$ for PCB- (TSCA) and RCRA-contaminated mixed waste debris. For TSCA/RCRA mixed waste soils, solids, and acceptable sludges, the estimator provided the lower cost of $\$ 1.40 / \mathrm{lb}$. Overall, the estimator gave a cost of over $\$ 3.6$ million for treating all the OH PCB/RCRA contaminated mixed waste solids. 


\section{Technology: Potential Organic Treatment Process (WCS)}

Class: Organic removal or aqueous based alternative oxidation process

Maturity (for PCB Mixed Waste):

Vendor: Waste Control Specialists (WCS), Pasadena, Texas (Andrews County). May be providing one or two treatment methods for PCB mixed waste under the Broad Spectrum Treatment contract. These include Sepradyne's thermal desorption process, Commodore's solvated electron process, and/or a direct chemical oxidation process.

Contact: John Lash, 865-220-0400

Related Web information: http://www.bechteljacobs.com/broadspectrum/vendor2.htm

http://www.commodore.com/applied/tech/techtsolvatedtech.htm

http://www.commodore.com/applied/tech/techapps.htm

http://www.llnl.gov/IPandC/op96/03/3o-dir.html

http://ost.em.doe.gov/ifd/mwfa/itsrs/itsr109/itsr109.pdf

\section{Technology Area}

Technology Description. Several different treatment alternatives are being evaluated. A specific PCB treatment technology has not yet been selected. WCS is awaiting a volume and waste profile determination by DOE in order to select the most robust technology. Three technologies that WCS has identified and is considering include:

- Commodore's solvated electron process - destruction or neutralization of the halogenated materials that rank among the world's most persistent toxic pollutants. The process is totally effective in destroying PCBs, dioxins, pesticides, fungicides, herbicides, CFCs, HCFCs, and chemical warfare agents. The system operates in a nonthermal destruction atmosphere under low pressure, is a closed system producing no hazardous off-gases, provides volume reduction, and produces no toxic by-products such as dioxins or furans or their precursors. In the case of a PCB molecule, the halogen atoms are stripped from the halogenated organic compound and converted to sodium chloride; the biphenyl functionality is also destroyed. The carbon skeleton is converted to non-conjugated hydrocarbons and rendered nontoxic.

- Direct chemical oxidation process - Direct chemical oxidation (DCO) is a nonthermal, ambientpressure, aqueous-based technology for the oxidative destruction of the organic components of hazardous or mixed waste streams. This specific alternative would use a catalyst to demonstrate the effectiveness of the technology at temperatures closer to ambient. (Normal operation temperature is $80-100^{\circ} \mathrm{C}$ ).

\section{Specific Throughputs}

- Commodore's solvated electron process (for PCBs) — soils, sludges, oils, porous debris, nonporous debris, waste water residues

- Direct chemical oxidation process - paper and rags; bulk chemicals; TNT and explosives; chlorinated solvents; kerosene and oils; nitrate, sulfate, or chlorine-rich compounds; PCBs; and chemical-warfare agents

\section{Waste Acceptance}

Questions related to the WCS WAC can be answered at the WCS WAC web site, http://www. wcstexas.com/html/wcs_wac.html. The current storage capacity at the WCS facility is 5000 drum equivalents of PCB mixed waste. 


\section{Schedule, Cost, and Other Logistics}

In June 1998, WCS was awarded a significant portion of the DOE Broad Spectrum contract. All DOE facilities can utilize this contract vehicle (through Bechtel-Jacobs at Oak Ridge) to ship the following generic waste streams to the WCS Texas facility for treatment, storage, and possible disposal:

1. non-TSCA wastes - RCRA hazardous waste with metals and insignificant organics requiring treatment primarily for metals;

2. TSCA-only waste with organics.

WCS accepts waste for temporary storage at its facility. WCS currently holds the Oak Ridge Broad Spectrum waste category E contract for treating and disposing both TSCA (PCB) and non-RCRA mixed waste solids

Use of the Oak Ridge Broad Spectrum contract's pricing estimator on the Bechtel-Jacobs web site, http://www.bechteljacobs.com/broadspectrum/prices.htm, provided approximate costs for the treatment of PCB/non-RCRA mixed waste solids via WCS. Even though a particular technology was not specified (e.g., Sepradyne, DCO, Commodore's SoLV-Ex), this estimator gave treatment costs of $\$ 6.45 / \mathrm{lb}$ for all types of PCB (TSCA) except non-RCRA contaminated mixed waste solids. 


\section{Appendix E - Cost Analysis}


Ashtabula Environmental Management Project

AEMP Alternatives Cost Analysis

\begin{tabular}{|c|c|c|c|c|c|c|c|c|c|c|}
\hline \multirow{3}{*}{ Alternative } & \multirow{2}{*}{$\begin{array}{c}\text { Direct } \\
\text { Disposal at } \\
\text { Envirocare }\end{array}$} & \multirow{2}{*}{$\begin{array}{c}\text { Commercial } \\
\text { at ATG }\end{array}$} & \multicolumn{2}{|c|}{ BS Contract } & \multirow{2}{*}{$\begin{array}{l}\text { Commercial } \\
\text { at Perma-Fix }\end{array}$} & \multicolumn{2}{|c|}{ Treatment On-Site } & \multicolumn{3}{|c|}{ Additional Cost to Store for 5 years } \\
\hline & & & WCS & M\&EC & & $\begin{array}{c}\text { Molten } \\
\text { Aluminum }\end{array}$ & $\begin{array}{l}\text { Soil Wash \& } \\
\text { Solvent Ext. }\end{array}$ & $\begin{array}{l}\text { On-Site at } \\
\text { Plant } 1\end{array}$ & $\begin{array}{l}\text { Off-Site at } \\
\text { Plant } 2\end{array}$ & $\begin{array}{c}\begin{array}{c}\text { Off-Site Out } \\
\text { of State }\end{array} \\
\end{array}$ \\
\hline & 1 & 2 & 3 & 4 & 5 & 6 & 7 & $8 \mathrm{~A}$ & 8B & $8 \mathrm{C}$ \\
\hline Solid Waste Volume Ft3 & 12,500 & 12,500 & 12,500 & 12,500 & 12,500 & 12,500 & 12,500 & 12,500 & 12,500 & 12,500 \\
\hline Density lb/ft3 & 100.0 & 100.0 & 100.0 & 100.0 & 100.0 & 100.0 & 100.0 & 100.0 & 100.0 & 100.0 \\
\hline Waste Weight Ib & $1,250,000$ & $1,250,000$ & $1,250,000$ & $1,250,000$ & $1,250,000$ & $1,250,000$ & $1,250,000$ & $1,250,000$ & $1,250,000$ & $1,250,000$ \\
\hline Liquid Waste Created Ib & 0 & 0 & 0 & 0 & 0 & 0 & 262,000 & 0 & 0 & 0 \\
\hline \multicolumn{11}{|l|}{ Treatment } \\
\hline Waste Characterization & $\$ 20,000$ & $\$ 20,000$ & $\$ 20,000$ & $\$ 20,000$ & $\$ 20,000$ & $\$ 0$ & $\$ 20,000$ & $\$ 20,000$ & $\$ 20,000$ & $\$ 20,000$ \\
\hline Waste Packaging & $\$ 362,500$ & $\$ 362,500$ & $\$ 362,500$ & $\$ 362,500$ & $\$ 362,500$ & $\$ 90,625$ & $\$ 181,250$ & $\$ 362,500$ & $\$ 362,500$ & $\$ 362,500$ \\
\hline Waste Shipment to & $\$ 0$ & $\$ 137,500$ & $\$ 62,500$ & $\$ 50,000$ & $\$ 62,500$ & $\$ 0$ & $\$ 0$ & $\$ 0$ & $\$ 11,250$ & $\$ 129,500$ \\
\hline Waste Storage & $\$ 0$ & $\$ 0$ & $\$ 0$ & $\$ 0$ & $\$ 0$ & $\$ 0$ & $\$ 0$ & $\$ 287,500$ & $\$ 343,750$ & $\$ 250,000$ \\
\hline Waste Treatment & $\$ 0$ & $\$ 10,000,000$ & $\$ 9,275,000$ & $\$ 2,025,000$ & $\$ 2,025,000$ & $\$ 500,000$ & $\$ 679,525$ & $\$ 0$ & $\$ 0$ & $\$ 0$ \\
\hline $\begin{array}{l}\text { Treated Waste } \\
\text { Characterization }\end{array}$ & $\$ 0$ & $\$ 0$ & & & & $\$ 43,750$ & $\$ 46,597$ & $\$ 0$ & $\$ 0$ & $\$ 0$ \\
\hline Treated Waste Packaging & $\$ 0$ & $\$ 0$ & $\$ 173,875$ & $\$ 353,215$ & $\$ 353,438$ & $\$ 253,750$ & $\$ 137,050$ & $\$ 0$ & $\$ 0$ & $\$ 0$ \\
\hline Treated Waste Shipment & $\$ 129,500$ & $\$ 17,552$ & $\$ 130,000$ & $\$ 131,168$ & $\$ 112,500$ & $\$ 90,650$ & $\$ 54,820$ & $\$ 0$ & $\$ 0$ & $\$ 0$ \\
\hline Land Fill Disposal & $\$ 0$ & $\$ 0$ & $\$ 0$ & $\$ 0$ & $\$ 0$ & $\$ 19,207$ & $\$ 0$ & $\$ 0$ & $\$ 0$ & $\$ 0$ \\
\hline Mixed Waste Disposal & $\$ 312,500$ & $\$ 0$ & $\$ 0$ & $\$ 0$ & $\$ 0$ & $\$ 0$ & $\$ 171,312$ & $\$ 0$ & $\$ 0$ & $\$ 0$ \\
\hline LLWaste Disposal & $\$ 0$ & $\$ 70,209$ & $\$ 130,000$ & $\$ 149,906$ & $\$ 150,000$ & $\$ 26,486$ & $\$ 54,820$ & $\$ 0$ & $\$ 0$ & $\$ 0$ \\
\hline $\begin{array}{l}\text { Liquid Waste Disposal } \\
\text { @TSCA }\end{array}$ & $\$ 0$ & $\$ 0$ & $\$ 0$ & $\$ 0$ & $\$ 0$ & $\$ 0$ & $\$ 1,048,000$ & & & \\
\hline Total Treatment & $\$ 824,500$ & $\$ 10,607,761$ & $\$ 10,153,875$ & $\$ 3,091,789$ & $\$ 3,085,938$ & $\$ 1,024,468$ & $\$ 2,393,374$ & $\$ 670,000$ & $\$ 737,500$ & $\$ 762,000$ \\
\hline Total \$\$/Ft3 & $\$ 65.96$ & $\$ 848.62$ & $\$ 812.31$ & $\$ 247.34$ & $\$ 246.88$ & $\$ 81.96$ & $\$ 191.47$ & $\$ 53.60$ & $\$ 59.00$ & $\$ 60.96$ \\
\hline Total $\$ \$ / / b$ & $\$ 0.66$ & $\$ 8.49$ & $\$ 8.12$ & $\$ 2.47$ & $\$ 2.47$ & $\$ 0.82$ & $\$ 1.91$ & $\$ 0.54$ & $\$ 0.59$ & $\$ 0.61$ \\
\hline
\end{tabular}


AEMP Alternatives Cost Analysis (continued)

\begin{tabular}{|c|c|c|c|c|c|c|c|c|c|c|}
\hline \multirow{3}{*}{ Alternative } & \multirow{2}{*}{$\begin{array}{c}\text { Direct } \\
\text { Disposal at } \\
\text { Envirocare }\end{array}$} & \multirow{2}{*}{$\begin{array}{c}\text { Commercial } \\
\text { at ATG }\end{array}$} & \multicolumn{2}{|c|}{ BS Contract } & \multirow{2}{*}{$\begin{array}{l}\text { Commercial } \\
\text { at Perma-Fix }\end{array}$} & \multicolumn{2}{|c|}{ Treatment On-Site } & \multicolumn{3}{|c|}{ Additional Cost to Store for 5 years } \\
\hline & & & wCS & M\&EC & & $\begin{array}{c}\text { Molten } \\
\text { Aluminum }\end{array}$ & $\begin{array}{l}\text { Soil Wash \& } \\
\text { Solvent Ext. }\end{array}$ & $\begin{array}{l}\text { On-Site at } \\
\text { Plant } 1\end{array}$ & $\begin{array}{l}\text { Off-Site at } \\
\text { Plant } 2\end{array}$ & $\begin{array}{l}\text { Off-Site Out } \\
\text { of State }\end{array}$ \\
\hline & 1 & 2 & 3 & 4 & 5 & 6 & 7 & $8 \mathrm{~A}$ & $8 \mathrm{~B}$ & $8 \mathrm{C}$ \\
\hline $\begin{array}{l}\text { RMI System Install, } \\
\text { Startup, \& Decommission } \\
\text { Engineering \& Project } \\
\text { Management } \\
\text { Plans, Permits, \& } \\
\text { Procedures } \\
\text { Material \& Equipment } \\
\text { Purchases } \\
\text { System Installation } \\
\text { System Startup } \\
\text { System Decommissioning } \\
\text { Total System } \\
\text { Implementation Cost } \\
\text { Total \$\$/Ft3 } \\
\text { Total \$ \$/lb }\end{array}$ & & & & & & $\begin{array}{c}\$ 100,000 \\
\$ 200,000 \\
\$ 1,800,000 \\
\$ 150,000 \\
\$ 100,000 \\
\$ 500,000 \\
\$ 2,850,000 \\
\$ 228.00 \\
\$ 2.28\end{array}$ & $\begin{array}{c}\$ 50,000 \\
\$ 100,000 \\
\$ 20,000 \\
\$ 135,000 \\
\$ 40,000 \\
\$ 50,000 \\
\$ 395,000 \\
\$ \mathbf{3 1 . 6 0} \\
\$ \mathbf{0 . 3 2}\end{array}$ & & & \\
\hline $\begin{array}{l}\text { Grand Total Treatment } \\
\text { plus Installation }\end{array}$ & $\$ 824,500$ & $\$ 10,607,761$ & $\$ 10,153,875$ & $\$ 3,091,789$ & $\$ 3,085,938$ & $\$ 3,874,468$ & $\$ 2,788,374$ & & & \\
\hline Total $\$$ \$Ft3 & $\$ 65.96$ & $\$ 848.62$ & $\$ 812.31$ & $\$ 247.34$ & $\$ 246.88$ & $\$ 309.96$ & $\$ 223.07$ & & & \\
\hline Total $\$ \$ / \mathrm{lb}$ & $\$ 0.66$ & $\$ 8.49$ & $\$ 8.12$ & $\$ 2.47$ & $\$ 2.47$ & $\$ 3.10$ & $\$ 2.23$ & & & \\
\hline
\end{tabular}


AEMP Data Entry

\begin{tabular}{|c|c|c|c|c|c|c|c|c|c|c|}
\hline \multirow{3}{*}{ Data: } & \multirow{2}{*}{\begin{tabular}{|c|} 
Direct \\
Disposal at \\
Envirocare
\end{tabular}} & \multirow{2}{*}{$\begin{array}{c}\text { Commercial } \\
\text { at ATG }\end{array}$} & \multicolumn{2}{|c|}{ BS Contract } & \multirow{2}{*}{$\begin{array}{l}\text { Commercial } \\
\text { at Perma-Fix }\end{array}$} & \multicolumn{2}{|c|}{ Treatment On-Site } & \multicolumn{3}{|c|}{ Storage for 5 years and Treat/Dispose } \\
\hline & & & WCS & M\&EC & & $\begin{array}{c}\text { Molten } \\
\text { Aluminum }\end{array}$ & $\begin{array}{l}\text { Soil Wash \& } \\
\text { Solvent Ext. }\end{array}$ & $\begin{array}{l}\text { On-Site at } \\
\text { Plant } 1\end{array}$ & $\begin{array}{l}\text { Off-Site at } \\
\text { Plant } 2\end{array}$ & $\begin{array}{c}\text { Off-Site Out of } \\
\text { State }\end{array}$ \\
\hline & 1 & 2 & 3 & 4 & 5 & 6 & 7 & $8 \mathrm{~A}$ & $8 \mathrm{~B}$ & $8 \mathrm{C}$ \\
\hline Waste Volume Ft3 & 12,500 & 12,500 & 12,500 & 12,500 & 12,500 & 12,500 & 12,500 & 12,500 & 12,500 & 12,500 \\
\hline Density lb/ft3 & 100.0 & 100.0 & 100.0 & 100.0 & 100.0 & 100.0 & 100.0 & 100.0 & 100.0 & 100.0 \\
\hline Waste Weight lb & $1,250,000$ & $1,250,000$ & $1,250,000$ & $1,250,000$ & $1,250,000$ & $1,250,000$ & $1,250,000$ & $1,250,000$ & $1,250,000$ & $1,250,000$ \\
\hline Liquid Waste produced & 0 & 0 & 0 & 0 & 0 & 0 & 262,000 & 0 & 0 & 0 \\
\hline $\begin{array}{l}\text { Treatment per Unit Weight or } \\
\text { Volume } \\
\text { Waste Characterization } \$ / \mathrm{ft} 3\end{array}$ & $\$ 1.60$ & $\$ 1.60$ & $\$ 1.60$ & $\$ 1.60$ & $\$ 1.60$ & $\$ 0.00$ & $\$ 1.60$ & $\$ 1.60$ & $\$ 1.60$ & $\$ 1.60$ \\
\hline Waste Packaging \$/ft3 & $\$ 29.00$ & $\$ 29.00$ & $\$ 29.00$ & $\$ 29.00$ & $\$ 29.00$ & $\$ 7.25$ & $\$ 14.50$ & $\$ 29.00$ & $\$ 29.00$ & $\$ 29.00$ \\
\hline $\begin{array}{l}\text { Waste Shipment to treatment } \\
\text { or Storage } \$ / \mathrm{ft} 3\end{array}$ & $\$ 0.00$ & $\$ 11.00$ & $\$ 5.00$ & $\$ 4.00$ & $\$ 5.00$ & $\$ 0.00$ & $\$ 0.00$ & $\$ 0.00$ & $\$ 0.90$ & $\$ 10.36$ \\
\hline Waste Storage $\$ / \mathrm{ft} 3$ for 5 years & $\$ 0.00$ & $\$ 0.00$ & $\$ 0.00$ & $\$ 0.00$ & $\$ 0.00$ & $\$ 0.00$ & $\$ 0.00$ & $\$ 23.00$ & $\$ 27.50$ & $\$ 20.00$ \\
\hline Waste Treatment $\$ / \mathrm{lb}$ & $\$ 0.00$ & $\$ 8.00$ & $\$ 7.42$ & $\$ 1.62$ & $\$ 1.62$ & $\$ 0.40$ & $\$ 0.54$ & $\$ 0.00$ & $\$ 0.00$ & $\$ 0.00$ \\
\hline $\begin{array}{l}\text { Treated Waste } \\
\text { Characterization } \$ / \mathrm{ft} 3\end{array}$ & $\$ 0.00$ & $\$ 0.00$ & $\$ 0.00$ & $\$ 0.00$ & $\$ 0.00$ & $\$ 5.00$ & $\$ 3.40$ & $\$ 0.00$ & $\$ 0.00$ & $\$ 0.00$ \\
\hline Treated Waste Packaging $\$ / \mathrm{ft} 3$ & $\$ 0.00$ & $\$ 0.00$ & $\$ 10.70$ & $\$ 18.85$ & $\$ 18.85$ & $\$ 29.00$ & $\$ 10.00$ & $\$ 0.00$ & $\$ 0.00$ & $\$ 0.00$ \\
\hline Treated Waste Shipment \$/ft3 & $\$ 10.36$ & $\$ 2.00$ & $\$ 8.00$ & $\$ 7.00$ & $\$ 6.00$ & $\$ 10.36$ & $\$ 4.00$ & $\$ 0.00$ & $\$ 0.00$ & $\$ 0.00$ \\
\hline Land fill disposal \$/ft3 & $\$ 2.75$ & $\$ 2.75$ & $\$ 2.75$ & $\$ 2.75$ & $\$ 2.75$ & $\$ 2.75$ & $\$ 2.75$ & & & \\
\hline MW Waste Disposal \$/ft3 & $\$ 25.00$ & $\$ 25.00$ & $\$ 25.00$ & $\$ 25.00$ & $\$ 25.00$ & $\$ 0.00$ & $\$ 25.00$ & & & \\
\hline LL Waste Disposal \$/ft3 & $\$ 8.00$ & $\$ 8.00$ & $\$ 8.00$ & $\$ 8.00$ & $\$ 8.00$ & $\$ 15.00$ & $\$ 8.00$ & & & \\
\hline $\begin{array}{l}\text { Liquid Waste Treatment at } \\
\text { TSCA } \$ / \text { lb }\end{array}$ & $\$ 4.00$ & $\$ 4.00$ & $\$ 4.00$ & $\$ 4.00$ & $\$ 4.00$ & $\$ 4.00$ & $\$ 4.00$ & & & \\
\hline$\%$ to Land Fill & $0 \%$ & $0 \%$ & $0 \%$ & $0 \%$ & $0 \%$ & $80 \%$ & $0 \%$ & & & \\
\hline$\%$ to $\mathrm{MW}$ & $100 \%$ & $0 \%$ & $0 \%$ & $0 \%$ & $0 \%$ & $0 \%$ & $50 \%$ & & & \\
\hline$\%$ to LLW & $0 \%$ & $100 \%$ & $100 \%$ & $100 \%$ & $100 \%$ & $20 \%$ & $50 \%$ & & & \\
\hline
\end{tabular}




\section{Fernald Environmental Management Project}

\section{FEMP Alternatives Cost Analysis}

\begin{tabular}{|c|c|c|c|c|c|c|}
\hline \multirow{3}{*}{ Alternative } & \multirow{2}{*}{$\begin{array}{c}\text { Commercial } \\
\text { ATG }\end{array}$} & \multirow{2}{*}{$\frac{\text { BS Contract }}{\text { M\&EC }}$} & \multirow{2}{*}{$\begin{array}{l}\text { Commercial } \\
\text { Permafix }\end{array}$} & \multicolumn{2}{|c|}{ Treatment On-Site } & \multirow{2}{*}{$\begin{array}{l}\text { Storage for } 5 \text { Years } \\
\text { Off-Site Out of State }\end{array}$} \\
\hline & & & & Solvent Extraction & Thermal Desorbtion & \\
\hline & 1 & 2 & 3 & 4 & 5 & 6 \\
\hline Solid Waste Volume Ft3 & 2,290 & 2,290 & 2,290 & 2,290 & 2,290 & 2,290 \\
\hline Density lbs/ft3 & 100.0 & 100.0 & 100.0 & 100.0 & 100.0 & 100.0 \\
\hline Waste Weight lbs & 229,000 & 229,000 & 229,000 & 229,000 & 229,000 & 229,000 \\
\hline Liquid Waste Created Ibs & & & & 57,250 & 11,450 & 0 \\
\hline Treatment & & & & & & \\
\hline Waste Characterization & $\$ 20,610$ & $\$ 20,610$ & $\$ 20,610$ & $\$ 20,610$ & $\$ 20,610$ & $\$ 20,610$ \\
\hline Waste Packaging & $\$ 163,506$ & $\$ 163,506$ & $\$ 163,506$ & $\$ 81,753$ & $\$ 81,753$ & $\$ 163,506$ \\
\hline Waste Shipment to Treatment or Storage & $\$ 70,234$ & $\$ 9,160$ & $\$ 24,434$ & $\$ 0$ & $\$ 0$ & $\$ 39,686$ \\
\hline Waste Storage & & $\$ 0$ & $\$ 0$ & $\$ 0$ & $\$ 0$ & $\$ 45,800$ \\
\hline Waste Treatment & $\$ 1,832,000$ & $\$ 370,980$ & $\$ 370,980$ & $\$ 1,145,000$ & $\$ 1,374,000$ & $\$ 0$ \\
\hline Treated Waste Characterization & $\$ 0$ & $\$ 0$ & $\$ 0$ & $\$ 30,915$ & $\$ 30,915$ & $\$ 0$ \\
\hline Treated Waste Packaging & $\$ 0$ & $\$ 64,709$ & $\$ 64,750$ & $\$ 245,259$ & $\$ 245,259$ & $\$ 0$ \\
\hline Treated Waste Shipment & $\$ 15,001$ & $\$ 86,954$ & $\$ 105,351$ & $\$ 105,351$ & $\$ 105,351$ & $\$ 0$ \\
\hline Land Fill Disposal & & & $\$ 0$ & $\$ 0$ & $\$ 0$ & $\$ 0$ \\
\hline Mixed Waste Disposal & $\$ 40,195$ & $\$ 85,821$ & $\$ 85,875$ & $\$ 85,875$ & $\$ 85,875$ & $\$ 0$ \\
\hline LLWaste Disposal & $\$ 0$ & $\$ 0$ & $\$ 0$ & $\$ 0$ & $\$ 0$ & $\$ 0$ \\
\hline Liquid Waste Disposal @TSCA & $\$ 0$ & $\$ 0$ & $\$ 0$ & $\$ 229,000$ & $\$ 45,800$ & $\$ 0$ \\
\hline Treatment Total & $\$ 2,141,545$ & $\$ 801,740$ & $\$ 835,507$ & $\$ 1,943,763$ & $\$ 1,989,563$ & $\$ 269,602$ \\
\hline Treatment $\$ \$ / \mathrm{Ft} 3$ & \$935.17 & $\$ 350.10$ & $\$ 364.85$ & $\$ 848.81$ & $\$ 868.81$ & $\$ 117.73$ \\
\hline Treatment $\$ \$ / / b$ & $\$ 9.35$ & $\$ 3.50$ & $\$ 3.65$ & $\$ 8.49$ & $\$ 8.69$ & $\$ 1.18$ \\
\hline FEMP Oversight & & & & & & \\
\hline Site Oversight Cost & $\$ 80,174$ & $\$ 80,174$ & $\$ 80,174$ & $\$ 971,881.73$ & $\$ 994,782$ & $\$ 26,960$ \\
\hline Oversight $\$ \$ / F t 3$ & $\$ 35.01$ & $\$ 35.01$ & $\$ 35.01$ & $\$ 424.40$ & $\$ 434.40$ & $\$ 11.77$ \\
\hline Oversight $\$ \$ / l b$ & $\$ 0.35$ & $\$ 0.35$ & $\$ 0.35$ & $\$ 4.24$ & $\$ 4.34$ & $\$ 0.12$ \\
\hline Grand Total: Treatment plus Oversight & $\$ 2,221,719$ & $\$ 881,914$ & $\$ 915,680$ & $\$ 2,915,645$ & $\$ 2,984,345$ & $\$ 296,562$ \\
\hline Grand Total \$\$/Ft3 & $\$ 970.18$ & $\$ 385.12$ & $\$ 399.86$ & $\$ 1,273.21$ & $\$ 1,303.21$ & $\$ 129.50$ \\
\hline Grand Total $\$ \$ / / b$ & $\$ 9.70$ & $\$ 3.85$ & $\$ 4.00$ & $\$ 12.73$ & $\$ 13.03$ & $\$ 1.30$ \\
\hline
\end{tabular}




\section{FEMP Data Entry}

\begin{tabular}{|c|c|c|c|c|c|c|}
\hline \multirow{3}{*}{ Data: } & \multirow{2}{*}{$\begin{array}{c}\text { Commercial } \\
\text { ATG }\end{array}$} & \multirow{2}{*}{$\begin{array}{c}\text { BS Contract } \\
\text { M\&EC } \\
\end{array}$} & \multirow{2}{*}{$\begin{array}{l}\text { Commercial } \\
\text { Permafix }\end{array}$} & \multicolumn{2}{|c|}{ Treatment On-Site } & \multirow{2}{*}{$\begin{array}{l}\text { Storage for } 5 \text { Years } \\
\text { Off-Site Out of State }\end{array}$} \\
\hline & & & & Solvent Extraction & Thermal Desorbtion & \\
\hline & 1 & 2 & $\overline{3}$ & 4 & 5 & 6 \\
\hline Waste Volume Ft3 & 2,290 & 2,290 & 2,290 & 2,290 & 2,290 & 2,290 \\
\hline Density lbs/ft3 & 100.0 & 100.0 & 100.0 & 100.0 & 100.0 & 100.0 \\
\hline Waste Weight lbs & 229,000 & 229,000 & 229,000 & 229,000 & 229,000 & 229,000 \\
\hline Liquid Waste produced lbs & 0 & 0 & 0 & 57250 & 11450 & 0 \\
\hline Treatment per Unit Weight or Volume & & & & & & \\
\hline Waste Characterization $\$ / \mathrm{ft} 3$ & $\$ 9.00$ & $\$ 9.00$ & $\$ 9.00$ & $\$ 9.00$ & $\$ 9.00$ & $\$ 9.00$ \\
\hline Waste Packaging $\$ /$ ft3 & $\$ 71.40$ & $\$ 71.40$ & $\$ 71.40$ & $\$ 35.70$ & $\$ 35.70$ & $\$ 71.40$ \\
\hline Waste Shipment to treatment or Storage $\$ / \mathrm{tt} 3$ & $\$ 30.67$ & $\$ 4.00$ & $\$ 10.67$ & $\$ 0.00$ & $\$ 0.00$ & $\$ 17.33$ \\
\hline Waste Storage $\$ / \mathrm{ft} 3$ for 5 years & $\$ 0.00$ & $\$ 0.00$ & $\$ 0.00$ & $\$ 0.00$ & $\$ 0.00$ & $\$ 20.00$ \\
\hline Waste Treatment $\$ / \mathrm{lb}$ & $\$ 8.00$ & $\$ 1.62$ & $\$ 1.62$ & $\$ 5.00$ & $\$ 6.00$ & $\$ 0.00$ \\
\hline Treated Waste Characterization $\$ / \mathrm{ft} 3$ & $\$ 0.00$ & $\$ 0.00$ & $\$ 0.00$ & $\$ 9.00$ & $\$ 9.00$ & $\$ 0.00$ \\
\hline Treated Waste Packaging $\$ / \mathrm{ft} 3$ & $\$ 0.00$ & $\$ 18.85$ & $\$ 18.85$ & $\$ 71.40$ & $\$ 71.40$ & $\$ 0.00$ \\
\hline Treated Waste Shipment $\$ / \mathrm{tt} 3$ & $\$ 9.33$ & $\$ 25.33$ & $\$ 30.67$ & $\$ 30.67$ & $\$ 30.67$ & $\$ 0.00$ \\
\hline Land fill disposal \$/ft3 & $\$ 2.75$ & $\$ 2.75$ & $\$ 2.75$ & $\$ 2.75$ & $\$ 2.75$ & \\
\hline MW Disposal \$/ft3 & $\$ 25.00$ & $\$ 25.00$ & $\$ 25.00$ & $\$ 25.00$ & $\$ 25.00$ & \\
\hline LL Waste Disposal $\$ / \mathrm{ft} 3$ & $\$ 8.00$ & $\$ 8.00$ & $\$ 8.00$ & $\$ 15.00$ & $\$ 8.00$ & \\
\hline Liquid Waste Treatment at TSCA $\$ / \mathrm{lb}$ & $\$ 4.00$ & $\$ 4.00$ & $\$ 4.00$ & $\$ 4.00$ & $\$ 4.00$ & \\
\hline$\%$ to Land Fill & $0 \%$ & $0 \%$ & $0 \%$ & $0 \%$ & $0 \%$ & \\
\hline$\%$ to $\mathrm{MW}$ & $100 \%$ & $100 \%$ & $100 \%$ & $100 \%$ & $100 \%$ & \\
\hline$\%$ to LLW & $0 \%$ & $0 \%$ & $0 \%$ & $0 \%$ & $0 \%$ & \\
\hline Site Oversight \% & $10 \%$ & $10 \%$ & $10 \%$ & $50 \%$ & $50 \%$ & $10 \%$ \\
\hline Waste Treatment Volume Change $\%$ & $70 \%$ & $150 \%$ & $150 \%$ & $150 \%$ & $150 \%$ & $100 \%$ \\
\hline
\end{tabular}




\section{Appendix F - Uncertainty Analysis}




\section{Uncertainty Analysis for AEMP}

Crystal Ball Report

Simulation started on $8 / 14 / 00$ at 10:43:52

Simulation stopped on $8 / 14 / 00$ at 10:44:03

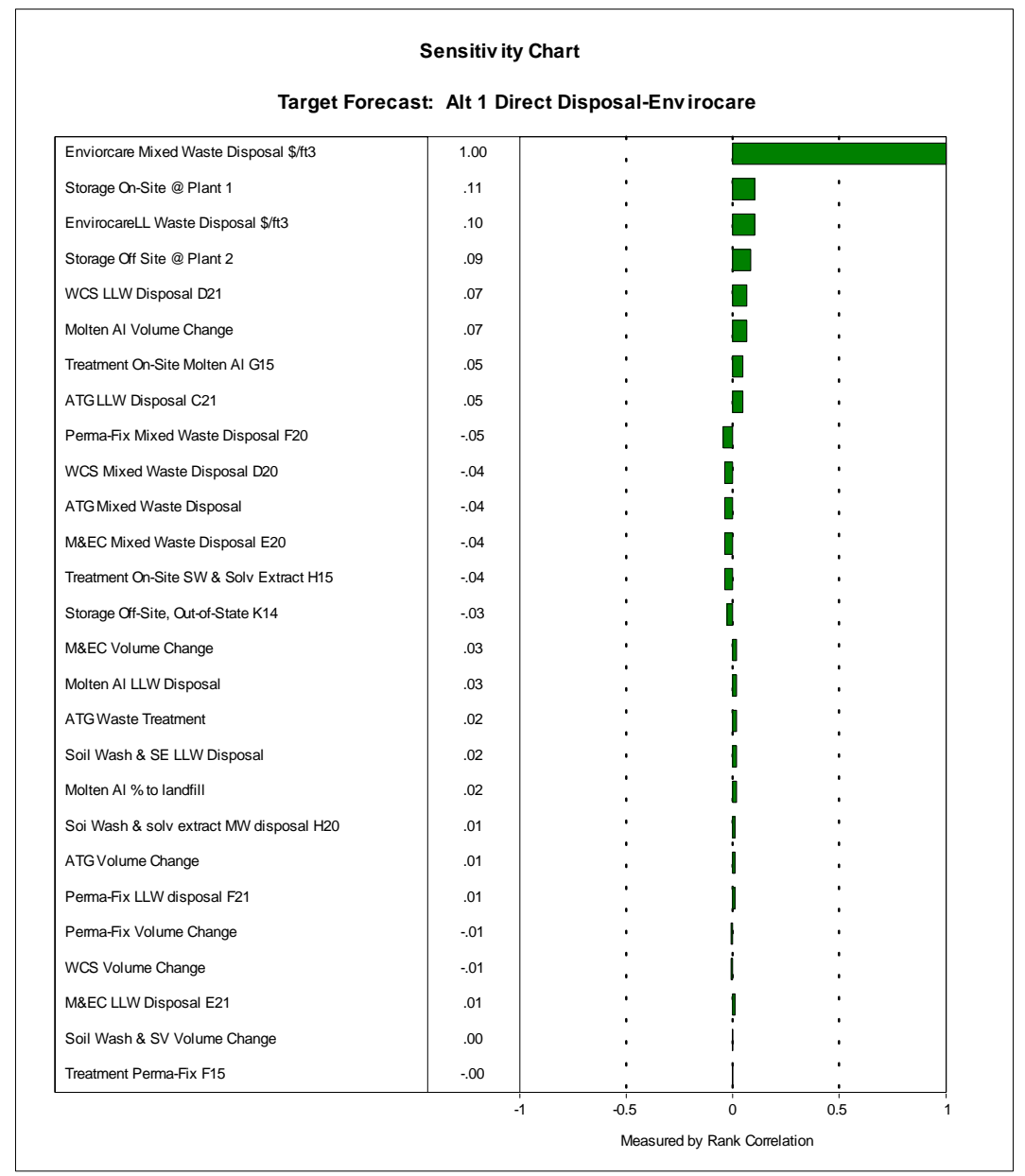


Forecast Alt 1 Direct Disposal-Envirocare

Summary:

Certa inty Level is $80.00 \%$

Certa inty Range is from $\$ 818,438$ to $\$ 910,514$ Dollars

Display Range is from $\$ 775,000$ to $\$ 950,000$ Dollars

Entire Range is from $\$ 793,476$ to $\$ 948,264$ Dollars

After 500 Trials, the Std. Error of the Mean is $\$ 1,459$

Sta tistic S:

Trials

Value

Mean

500

Median

$\$ 854,628$

Mode

$\$ 850,398$

Standard Deviation

$\$ 32,618$

Variance

$\$ 1,063,910,977$

Skewness

0.49

Kurtosis

2.56

Coeff. of Variability

0.04

Range Minimum

$\$ 793,476$

Range Maximum

$\$ 948,264$

Range Width

$\$ 154,788$

Mean Std. Error

$\$ 1,458.71$

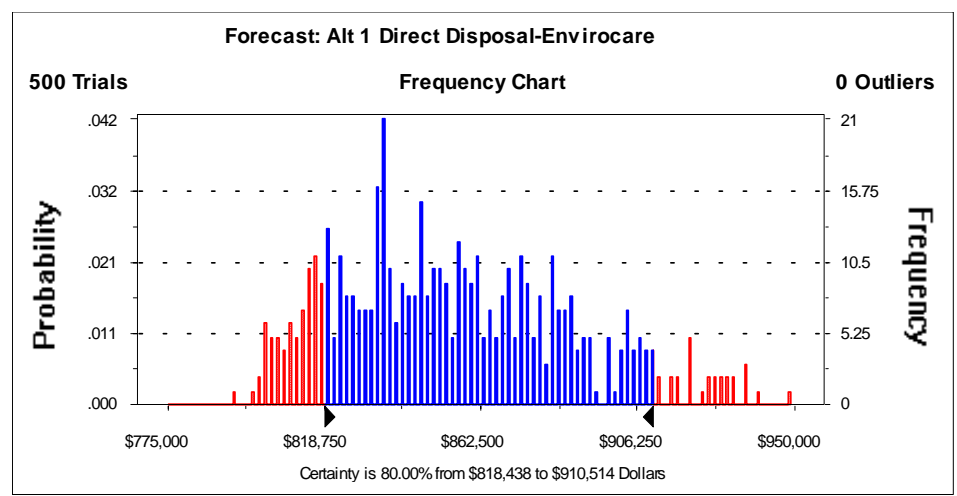


Forecast Alt 1 Direct Disposal-Envirocare (contd)

\section{Cell: B41}

Percentiles:

\begin{tabular}{r} 
Percentile \\
\hline $0 \%$ \\
$10 \%$ \\
$20 \%$ \\
$30 \%$ \\
$40 \%$ \\
$50 \%$ \\
$60 \%$ \\
$70 \%$ \\
$80 \%$ \\
$90 \%$ \\
$100 \%$
\end{tabular}

Dollars

$\$ 793,476$

$\$ 814,808$

$\$ 823,735$

$\$ 834,368$

$\$ 841,362$

$\$ 850,398$

$\$ 859,874$

$\$ 871,201$

$\$ 883,080$

$\$ 902,860$

$\$ 948,264$

End of Forecast 
Forecast Alt 2 Treatment @ATG

Summary:

Certa inty Level is $80.00 \%$

Certa inty Range is from $\$ 9,255,448$ to $\$ 10,458,467$ Dollars

Display Range is from $\$ 9,000,000$ to $\$ 10,750,000$ Dollars

Entire Range is from $\$ 9,111,372$ to $\$ 10,629,348$ Dollars

After 500 Trials, the Std. Error of the Mean is $\$ 19,661$

$\begin{array}{lr}\text { Statistics: } & \text { Value } \\ \text { Trials } & 500 \\ \text { Mean } & \$ 9,887,339 \\ \text { Median } & \$ 9,899,622 \\ \text { Mode } & -- \\ \text { Standard Deviation } & \$ 439,632 \\ \text { Variance } & 2 \mathrm{E}+11 \\ \text { Skewness } & -0.04 \\ \text { Kurtosis } & 1.74 \\ \text { Coeff. of Variability } & 0.04 \\ \text { Range Minimum } & \$ 9,111,372 \\ \text { Range Maximum } & \$ 10,629,348 \\ \text { Range Width } & \$ 1,517,976 \\ \text { Mean Std. Error } & \$ 19,660.95\end{array}$

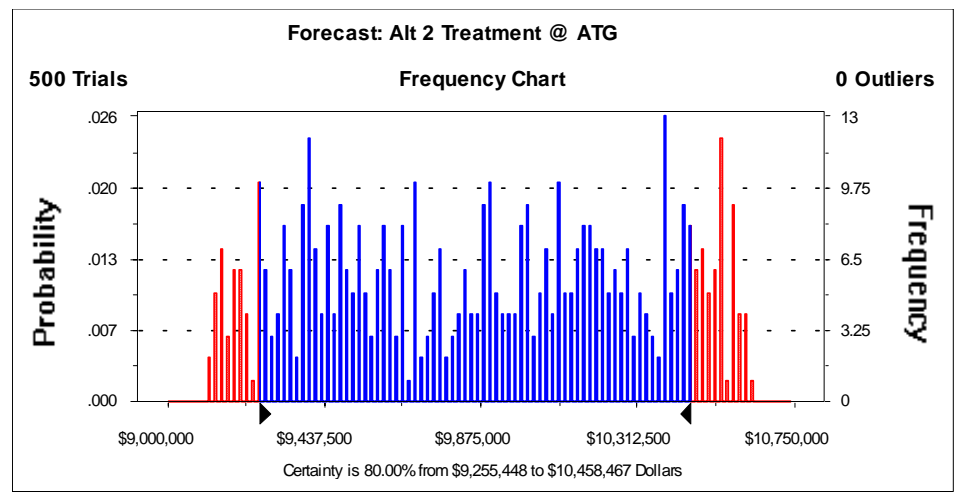


Forecast Alt 2 Treatment @ATG (contd)

\section{Cell: C41}

Percentiles:

Percentile
$0 \%$
$10 \%$
$20 \%$
$30 \%$
$40 \%$
$50 \%$
$60 \%$
$70 \%$
$80 \%$
$90 \%$
$100 \%$

Dollars

$\$ 9,111,372$

$\$ 9,274,858$

$\$ 9,417,363$

$\$ 9,558,325$

$\$ 9,728,765$

$\$ 9,899,622$

$\$ 10,060,726$

$\$ 10,189,932$

$\$ 10,356,199$

$\$ 10,485,872$

$\$ 10,629,348$

End of Forecast 
Forecast Alt 3 BS contract @WCS

Summary:

Certa inty Level is $80.00 \%$

Certainty Range is from $\$ 10,110,518$ to $\$ 10,232,311$ Dollars

Display Range is from $\$ 10,050,000$ to $\$ 10,275,000$ Dollars

Entire Range is from $\$ 10,071,676$ to $\$ 10,280,455$ Dollars

After 500 Tria ls, the Std. Error of the Mean is $\$ 1,967$

Sta tistic s:

Trials

Mean

alue

Median

$\$ 10,160,645$

Mode

$\$ 10,157,282$

Standard Deviation

$\$ 43,974$

Variance

$\$ 1,933,734,486$

Skewness

Kurtosis

Coeff. of Variability

0.00

Range Minimum

$\$ 10,071,676$

Range Maximum

$\$ 10,280,455$

Range Width

$\$ 208,779$

Mean Std. Error

$\$ 1,966.59$

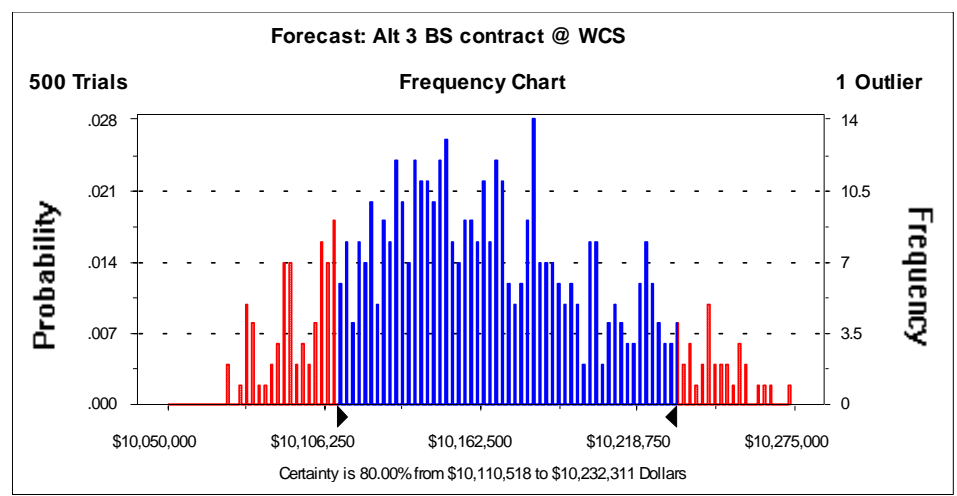


Forecast Alt 3 BS contract @WCS (contd)

\section{Cell: D41}

Percentiles:

\begin{tabular}{r} 
Percentile \\
\hline $0 \%$ \\
$10 \%$ \\
$20 \%$ \\
$30 \%$ \\
$40 \%$ \\
$50 \%$ \\
$60 \%$ \\
$70 \%$ \\
$80 \%$ \\
$90 \%$ \\
$100 \%$
\end{tabular}

Dollars
$\$ 10,071,676$
$\$ 10,105,657$
$\$ 10,120,996$
$\$ 10,134,105$
$\$ 10,145,176$
$\$ 10,157,282$
$\$ 10,168,643$
$\$ 10,182,357$
$\$ 10,201,354$
$\$ 10,222,388$
$\$ 10,280,455$

End of Forecast 
Forecast Alt 4 BSContract @ M\&EC

Summary:

Certa inty Level is $80.00 \%$

Certainty Range is from $\$ 3,019,564$ to $\$ 3,138,074$ Dollars

Display Range is from $\$ 2,975,000$ to $\$ 3,200,000$ Dollars

Entire Range is from $\$ 2,978,462$ to $\$ 3,198,039$ Dollars

After 500 Trials, the Std. Error of the Mean is $\$ 1,984$

Sta tistic S:

Trials

Value

Mean

500

Median

$\$ 3,073,381$

Mode

$\$ 3,071,583$

Standard Deviation

$\$ 44,360$

Variance

$\$ 1,967,822,691$

Skewness

0.23

Kurtosis

2.47

Coeff. of Variability

0.01

Range Minimum

$\$ 2,978,462$

Range Maximum

$\$ 3,198,039$

Range Width

$\$ 219,577$

Mean Std. Error

$\$ 1,983.85$

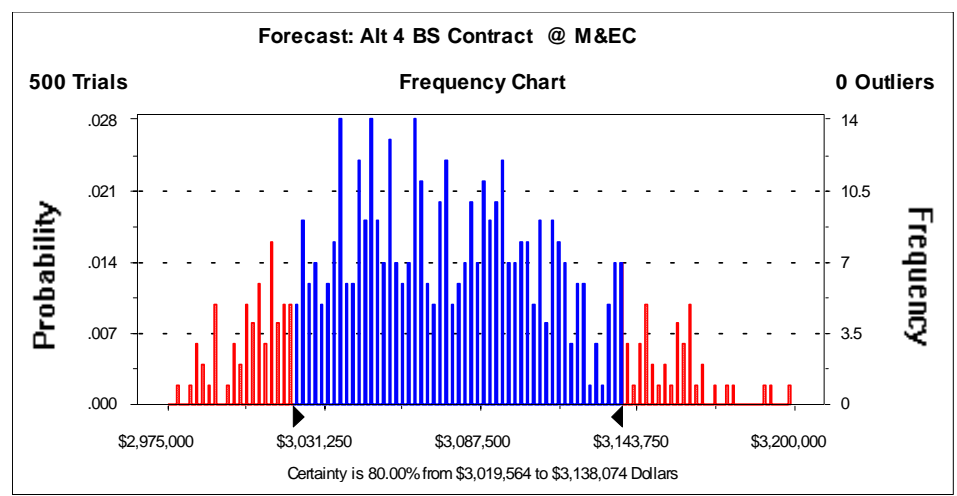


Forecast Alt 4 BSContract @M\&EC (contd)

\section{Cell: E41}

Percentiles:

Percentile
$0 \%$
$10 \%$
$20 \%$
$30 \%$
$40 \%$
$50 \%$
$60 \%$
$70 \%$
$80 \%$
$90 \%$
$100 \%$

Dollars

$\$ 2,978,462$

$\$ 3,016,141$

$\$ 3,034,072$

$\$ 3,046,494$

$\$ 3,057,009$

$\$ 3,071,583$

$\$ 3,084,944$

$\$ 3,096,487$

$\$ 3,112,972$

$\$ 3,135,230$

$\$ 3,198,039$

End of Forecast 
Forecast Alt 5 Treatment @ Perma-Fix

Summary:

Certa inty Level is $80.00 \%$

Certa inty Range is from $\$ 3,091,149$ to $\$ 3,474,560$ Dollars

Display Range is from $\$ 2,900,000$ to $\$ 3,600,000$ Dollars

Entire Range is from $\$ 2,979,049$ to $\$ 3,652,586$ Dollars

After 500 Trials, the Std. Error of the Mean is $\$ 5,780$

Statistic S:

Trials

Value

Mean

500

Median

$\$ 3,224,749$

Mode

$\$ 3,201,979$

Standard Deviation

$\$ 129,256$

Variance

$\$ 16,707,058,226$

Skewness

0.58

Kurtosis

2.73

Coeff. of Variability

0.04

Range Minimum

$\$ 2,979,049$

Range Maximum

$\$ 3,652,586$

Range Width

$\$ 673,537$

Mean Std. Error

$\$ 5,780.49$

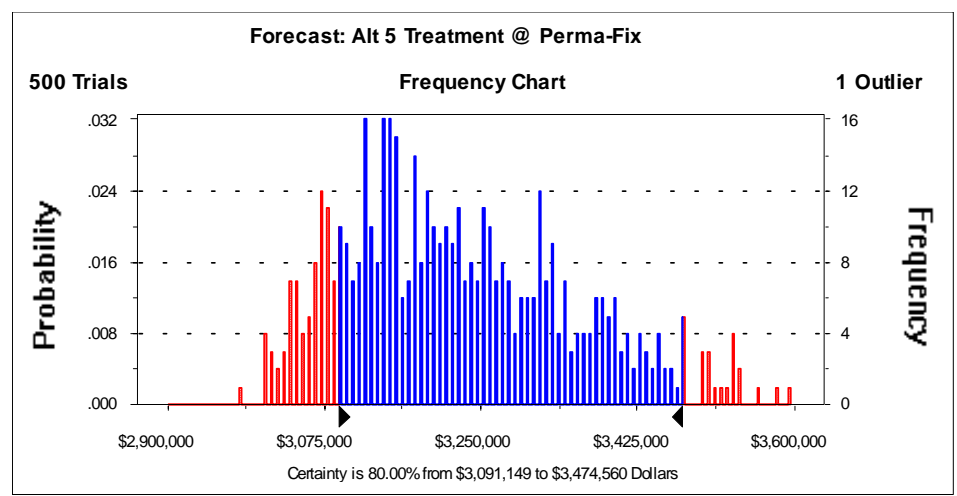


Forecast Alt 5 Treatment @ Perma-Fix (contd)

\section{Cell: F41}

Percentiles:

Percentile
$0 \%$
$10 \%$
$20 \%$
$30 \%$
$40 \%$
$50 \%$
$60 \%$
$70 \%$
$80 \%$
$90 \%$
$100 \%$

Dollars

$\$ 2,979,049$

$\$ 3,071,646$

$\$ 3,109,535$

$\$ 3,139,965$

$\$ 3,170,239$

$\$ 3,201,979$

$\$ 3,241,419$

$\$ 3,284,853$

$\$ 3,333,822$

$\$ 3,404,871$

$\$ 3,652,586$

End of Forecast 
Forecast Alt 6 Treatment On-Site with Molten Al

Summary:

Certa inty Level is $80.00 \%$

Certa inty Range is from $\$ 4,093,877$ to $\$ 5,627,014$ Dollars

Display Range is from $\$ 3,750,000$ to $\$ 6,000,000$ Dollars

Entire Range is from $\$ 3,780,591$ to $\$ 5,948,732$ Dollars

After 500 Trials, the Std. Error of the Mean is $\$ 25,136$

$\begin{array}{lr}\text { Statistics: } & \text { Value } \\ \text { Trials } & 500 \\ \text { Mean } & \$ 4,849,883 \\ \text { Median } & \$ 4,849,542 \\ \text { Mode } & --- \\ \text { Standard Deviation } & \$ 562,051 \\ \text { Variance } & 3 \mathrm{E}+11 \\ \text { Skewness } & 0.04 \\ \text { Kurtosis } & 1.87 \\ \text { Coeff. of Variability } & 0.12 \\ \text { Range Minimum } & \$ 3,780,591 \\ \text { Range Maximum } & \$ 5,948,732 \\ \text { Range Width } & \$ 2,168,141 \\ \text { Mean Std. Error } & \$ 25,135.68\end{array}$

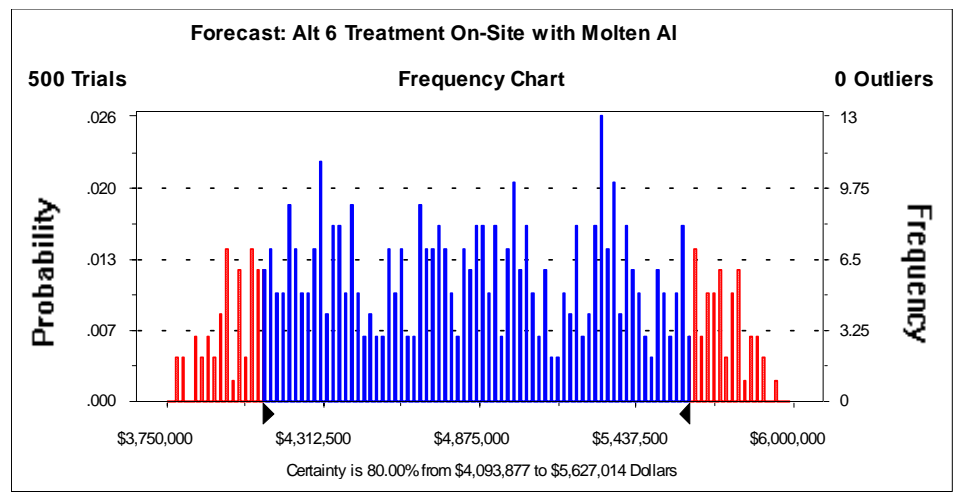


Forec ast Alt 6 Treatment On-Site with Molten Al (contd)

\section{Cell: G41}

Percentiles:

Percentile
$0 \%$
$10 \%$
$20 \%$
$30 \%$
$40 \%$
$50 \%$
$60 \%$
$70 \%$
$80 \%$
$90 \%$
$100 \%$

Dollars

$\$ 3,780,591$

$\$ 4,093,877$

$\$ 4,287,144$

$\$ 4,442,015$

$\$ 4,671,914$

$\$ 4,849,542$

$\$ 5,012,825$

$\$ 5,238,489$

$\$ 5,403,948$

$\$ 5,627,014$

$\$ 5,948,732$

End of Forecast 
Forec ast Alt 7 Treatment On-Site with SW \& SE

Summary:

Certa inty Level is $80.00 \%$

Certa inty Range is from $\$ 2,639,122$ to $\$ 3,232,353$ Dollars

Display Range is from $\$ 2,400,000$ to $\$ 3,400,000$ Dollars

Entire Range is from $\$ 2,464,439$ to $\$ 3,355,661$ Dollars

After 500 Trials, the Std. Error of the Mean is \$9,132

$\begin{array}{lr}\text { Statistic s: } & \text { Value } \\ \text { Trials } & 500 \\ \text { Mean } & \$ 2,847,754 \\ \text { Median } & \$ 2,815,608 \\ \text { Mode } & --- \\ \text { Standard Deviation } & \$ 204,197 \\ \text { Variance } & \$ 41,696,432,286 \\ \text { Skewness } & 0.43 \\ \text { Kurtosis } & 2.45 \\ \text { Coeff. of Variability } & 0.07 \\ \text { Range Minimum } & \$ 2,464,439 \\ \text { Range Maximum } & \$ 3,355,661 \\ \text { Range Width } & \$ 891,221 \\ \text { Mean Std. Error } & \$ 9,131.97\end{array}$

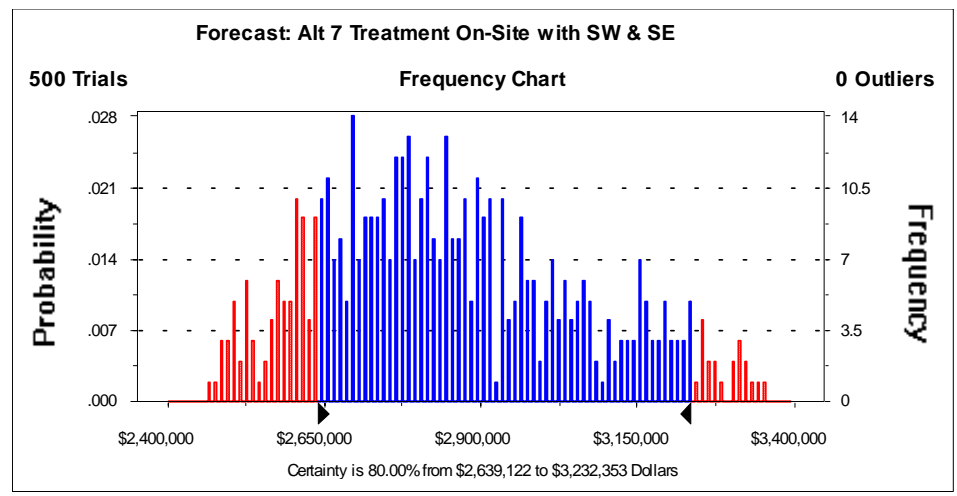


Forecast Alt 7 Treatment On-Site with SW \& SE (cont'd)

\section{Cell: H41}

Percentiles:

Percentile
$0 \%$
$10 \%$
$20 \%$
$30 \%$
$40 \%$
$50 \%$
$60 \%$
$70 \%$
$80 \%$
$90 \%$
$100 \%$

Dollars

$\$ 2,464,439$

$\$ 2,602,103$

$\$ 2,659,395$

$\$ 2,719,749$

$\$ 2,775,046$

$\$ 2,815,608$

$\$ 2,875,733$

$\$ 2,936,777$

$\$ 3,032,096$

$\$ 3,159,799$

$\$ 3,355,661$

End of Forecast 
Forecast Alt 8A Store On-Site Plant 1 - 5 Years

Summary:

Certa inty Level is $80.00 \%$

Certa inty Range is from $\$ 646,248$ to $\$ 706,385$

Display Range is from $\$ 620,000$ to $\$ 730,000$

Entire Range is from $\$ 622,507$ to $\$ 726,442$

After 500 Tria ls, the Std. Error of the Mean is $\$ 955$

$\begin{array}{lr}\text { Statistics: } & \text { Value } \\ \text { Trials } & 500 \\ \text { Mean } & \$ 675,659 \\ \text { Median } & \$ 675,889 \\ \text { Mode } & -- \\ \text { Standard Deviation } & \$ 21,354 \\ \text { Variance } & \$ 455,973,501 \\ \text { Skewness } & 0.01 \\ \text { Kurtosis } & 2.44 \\ \text { Coeff. of Variability } & 0.03 \\ \text { Range Minimum } & \$ 622,507 \\ \text { Range Maximum } & \$ 726,442 \\ \text { Range Width } & \$ 103,934 \\ \text { Mean Std. Error } & \$ 954.96\end{array}$

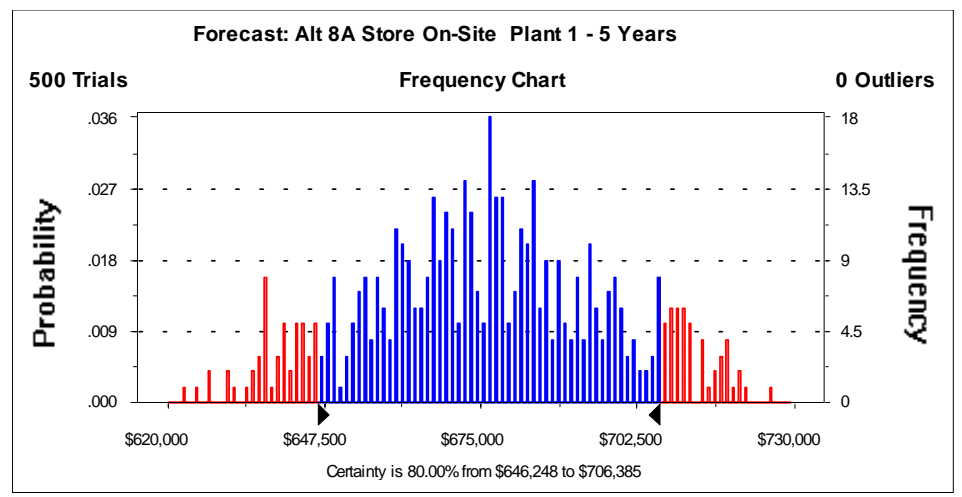


Forecast Alt 8A Store On-Site Plant 1 - 5 Years (contd)

Percentiles:

\begin{tabular}{r} 
Percentile \\
\hline $0 \%$ \\
$10 \%$ \\
$20 \%$ \\
$30 \%$ \\
$40 \%$ \\
$50 \%$ \\
$60 \%$ \\
$70 \%$ \\
$80 \%$ \\
$90 \%$ \\
$100 \%$
\end{tabular}

Value

$\$ 622,507$

$\$ 646,372$

$\$ 657,097$

$\$ 664,433$

$\$ 669,712$

$\$ 675,889$

$\$ 680,580$

$\$ 686,582$

$\$ 694,625$

$\$ 706,415$

$\$ 726,442$

End of Forecast 
Forecast Alt 8B Store Off-Site Plant 2- 5 Years

Summary:

Certa inty Level is $80.00 \%$

Certainty Range is from $\$ 698,412$ to $\$ 771,735$

Display Range is from $\$ 650,000$ to $\$ 825,000$

Entire Range is from $\$ 673,447$ to $\$ 800,251$

After 500 Tria ls, the Std. Error of the Mean is $\$ 1,244$

$\begin{array}{lr}\text { Statistics: } & \text { Value } \\ \text { Trials } & 500 \\ \text { Mean } & \$ 736,806 \\ \text { Median } & \$ 737,001 \\ \text { Mode } & --- \\ \text { Standard Deviation } & \$ 27,821 \\ \text { Variance } & \$ 774,014,703 \\ \text { Skewness } & 0.03 \\ \text { Kurtosis } & 2.47 \\ \text { Coeff. of Variability } & 0.04 \\ \text { Range Minimum } & \$ 673,447 \\ \text { Range Maximum } & \$ 800,251 \\ \text { Range Width } & \$ 126,804 \\ \text { Mean Std. Error } & \$ 1,244.20\end{array}$

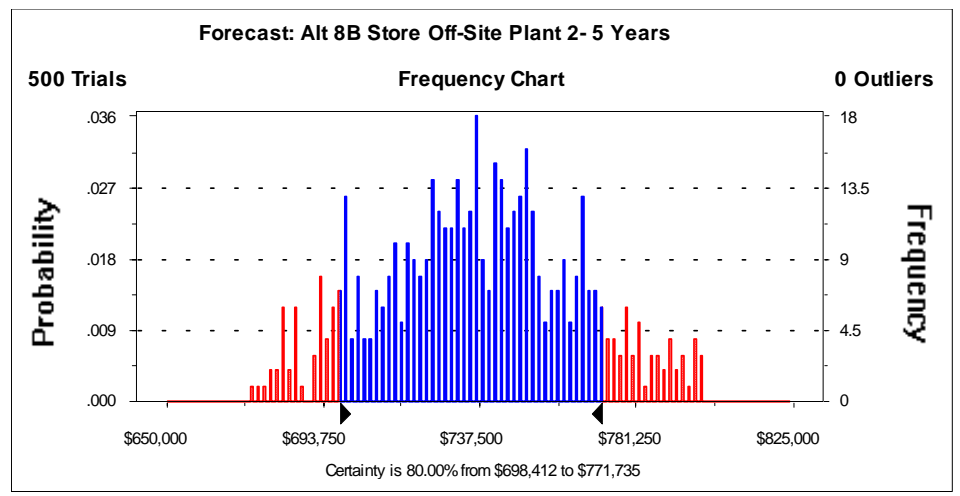


Forecast Alt 8B Store Off-Site Plant 2- 5 Years (contd)

Percentiles:

\begin{tabular}{rr} 
Percentile & Value \\
\hline $0 \%$ & $\$ 673,447$ \\
$10 \%$ & $\$ 698,955$ \\
$20 \%$ & $\$ 711,892$ \\
$30 \%$ & $\$ 722,521$ \\
$40 \%$ & $\$ 729,788$ \\
$50 \%$ & $\$ 737,001$ \\
$60 \%$ & $\$ 744,128$ \\
$70 \%$ & $\$ 750,895$ \\
$80 \%$ & $\$ 761,576$ \\
$90 \%$ & $\$ 772,686$ \\
$100 \%$ & $\$ 800,251$
\end{tabular}

End of Forecast 
Forecast Alt 8C Store Off-Site Out of State-5 Yea

Summary:

Certa inty Level is $80.00 \%$

Certa inty Range is from $\$ 660,257$ to $\$ 761,106$

Display Range is from $\$ 625,000$ to $\$ 800,000$

Entire Range is from $\$ 644,131$ to $\$ 785,709$

After 500 Tria ls, the Std. Error of the Mean is $\$ 1,435$

$\begin{array}{lr}\text { Statistics: } & \text { Value } \\ \text { Trials } & 500 \\ \text { Mean } & \$ 729,531 \\ \text { Median } & \$ 734,772 \\ \text { Mode } & --- \\ \text { Standard Deviation } & \$ 32,086 \\ \text { Variance } & \$ 1,029,481,865 \\ \text { Skewness } & -0.57 \\ \text { Kurtosis } & 2.59 \\ \text { Coeff. of Variability } & 0.04 \\ \text { Range Minimum } & \$ 644,131 \\ \text { Range Maximum } & \$ 785,709 \\ \text { Range Width } & \$ 141,578 \\ \text { Mean Std. Error } & \$ 1,434.91\end{array}$

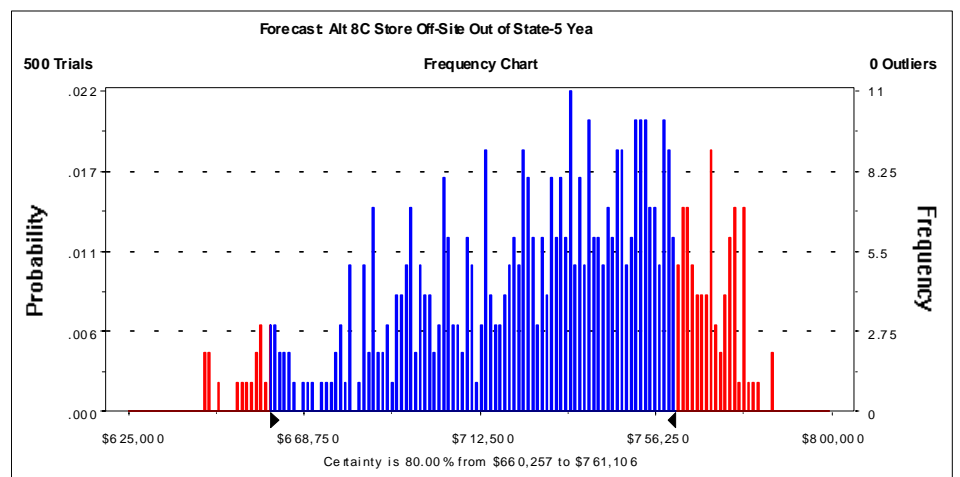


Forecast Alt 8C Store Off-Site Out of State-5 Yea (contd)

\section{Cell: K24}

Percentiles:

\begin{tabular}{r} 
Percentile \\
\hline $0 \%$ \\
$10 \%$ \\
$20 \%$ \\
$30 \%$ \\
$40 \%$ \\
$50 \%$ \\
$60 \%$ \\
$70 \%$ \\
$80 \%$ \\
$90 \%$ \\
$100 \%$
\end{tabular}

Value

$\$ 644,131$

$\$ 684,387$

$\$ 699,722$

$\$ 714,215$

$\$ 724,889$

$\$ 734,772$

$\$ 742,910$

$\$ 751,535$

$\$ 758,693$

$\$ 767,567$

$\$ 785,709$

End of Forecast 


\section{Assumptions}

Assumption: EnvirocareL Waste Disposal \$/ft3

Cell: B21

Triangular distribution with parameters:

Minimum

$\$ 5.00$

Likeliest

Maximum

$\$ 15.00$

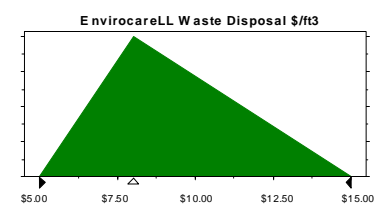

Selected range is from $\$ 5.00$ to $\$ 15.00$

Mean value in simulation was $\$ 9.37$

\section{Assumption: ATG UW Disposal C21}

Cell: C21

Triangula r distribution with pa ra meters:

$\begin{array}{lr}\text { Minimum } & \$ 5.00 \\ \text { Lkeliest } & \$ 8.00 \\ \text { Maximum } & \$ 15.00\end{array}$

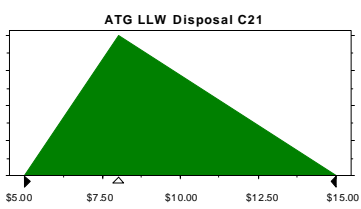

Selected range is from $\$ 5.00$ to $\$ 15.00$

Mean value in simulation was $\$ 9.30$

\section{Assumption: WCS WW Disposal D21}

Cell: D21

Triangular distribution with pa ra meters:

Minimum

Likeliest

Maximum

$\$ 15.00$

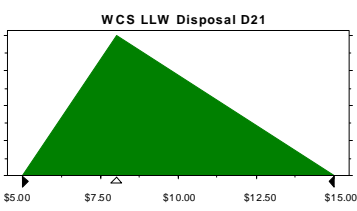

Selected range is from $\$ 5.00$ to $\$ 15.00$

Mean value in simulation was $\$ 9.45$

\section{Assumption: M\&EC WW Disposal E21}

\section{Cell: E21}

Triangular distribution with parameters:

Minimum

$\$ 5.00$

Likeliest

Maximum

$\$ 15.00$

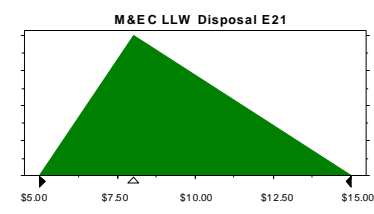

Selected range is from $\$ 5.00$ to $\$ 15.00$

Mean value in simulation was $\$ 9.38$ 
Assumption: Pema-Fix யW disposal F21

Triangular distribution with parameters:

$\begin{array}{lr}\text { Minimum } & \$ 5.00 \\ \text { Likeliest } & \$ 8.00 \\ \text { Maximum } & \$ 15.00\end{array}$

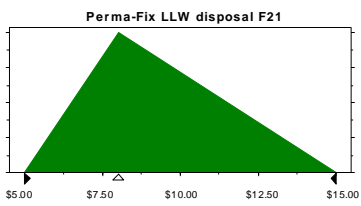

Selected range is from $\$ 5.00$ to $\$ 15.00$

Mean value in simulation was $\$ 9.44$

\section{Assumption: Soil Wash \& SE UW Disposal}

\section{Cell: H21}

Triangular distribution with parameters:

Minimum

Likeliest

Maximum

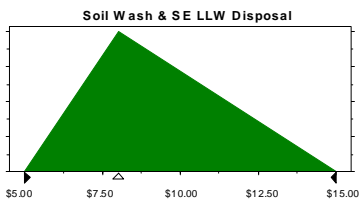

Selected range is from $\$ 5.00$ to $\$ 15.00$

Mean value in simulation was $\$ 9.46$

\section{Assumption: Molten AI யW Disposal}

Cell: G21

Triangular distribution with pa ra meters:

$\begin{array}{ll}\text { Minimum } & \$ 15.00 \\ \text { Likeliest } & \$ 15.00 \\ \text { Maximum } & \$ 31.00\end{array}$

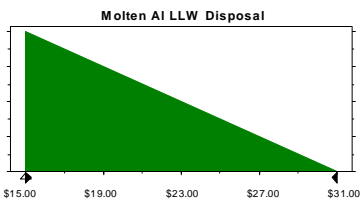

Selected range is from $\$ 15.00$ to $\$ 31.00$

Mean value in simulation was $\$ 19.99$

Assumption: Enviorcare Mixed Waste Disposal \$/ft3

Cell: B20

Triangular distribution with parameters:

$\begin{array}{ll}\text { Minimum } & \$ 22.50 \\ \text { Likeliest } & \$ 25.00 \\ \text { Maximum } & \$ 35.00\end{array}$

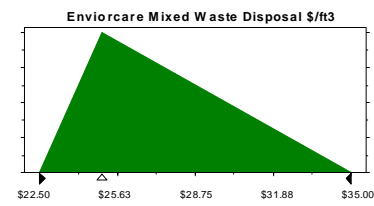

Selected range is from $\$ 22.00$ to $\$ 35.00$

Mean value in simulation was $\$ 27.41$ 
Assumption: ATG Mixed Waste Disposal

Triangular distribution with parameters:

$\begin{array}{ll}\text { Minimum } & \$ 22.50 \\ \text { Lkeliest } & \$ 25.00 \\ \text { Maximum } & \$ 35.00\end{array}$

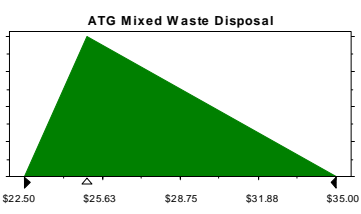

Selected range is from $\$ 22.00$ to $\$ 35.00$

Mean value in simulation was $\$ 27.32$

\section{Assumption: WCS Mixed Waste Disposal D20}

\section{Cell: D20}

Triangular distribution with parameters:

Minimum

$\$ 22.50$

Likeliest

$\$ 25.00$

Maximum

$\$ 35.00$

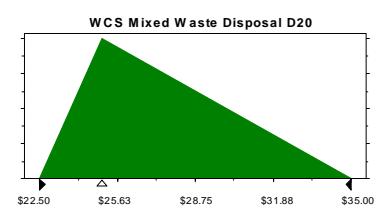

Selected range is from $\$ 22.00$ to $\$ 35.00$

Mean value in simulation was $\$ 27.65$

\section{Assumption: M\&EC Mixed Waste Disposal E20}

\section{Cell: E20}

Triangular distribution with pa ra meters:

$\begin{array}{ll}\text { Minimum } & \$ 22.50 \\ \text { Likeliest } & \$ 25.00 \\ \text { Maximum } & \$ 35.00\end{array}$

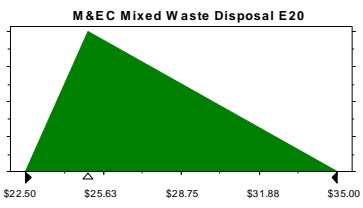

Selected range is from $\$ 22.00$ to $\$ 35.00$

Mean value in simulation was $\$ 27.46$

\section{Assumption: Perma-Fix Mixed Waste Disposal F20}

Cell: F20

Triangula r distribution with pa ra meters:

Minimum

Likeliest

$\$ 22.50$

Maximum

$\$ 25.00$

$\$ 35.00$

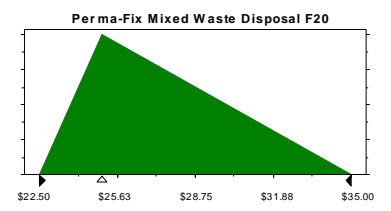

Selected range is from $\$ 22.00$ to $\$ 35.00$

Mean value in simulation was $\$ 27.38$ 
Assumption: Soi Wash \& solv extract MW disposal H2O

Cell: H2O

Triangular distribution with pa ra meters:

Minimum

$\$ 22.50$

Likeliest

$\$ 25.00$

Maximum

$\$ 35.00$

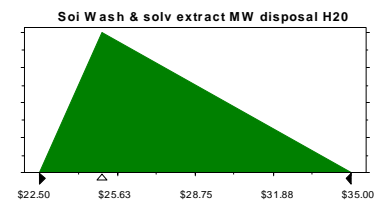

Selected range is from $\$ 22.00$ to $\$ 35.00$

Mean value in simulation was $\$ 27.52$

\section{Assumption: ATG Waste Treatment}

\section{Cell: C15}

Uniform distribution with parameters:

Minimum

Maximum

Mean value in simulation was $\$ 7.41$

\section{Assumption: Treatment Perma-Fix F15}

Cell: F15

Triangular distribution with parameters:

Minimum

$\$ 1.62$

Likeliest

$\$ 1.62$

Maximum

$\$ 2.00$

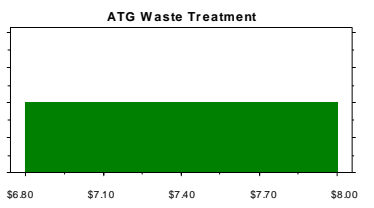

Selected range is from $\$ 1.62$ to $\$ 2.00$

Mean value in simulation was $\$ 1.74$

\section{Assumption: Treatment On-Site Molten Al G15}

\section{Cell: G15}

Uniform distribution with parameters:
Minimum
$\$ 0.40$
Maximum
$\$ 2.00$
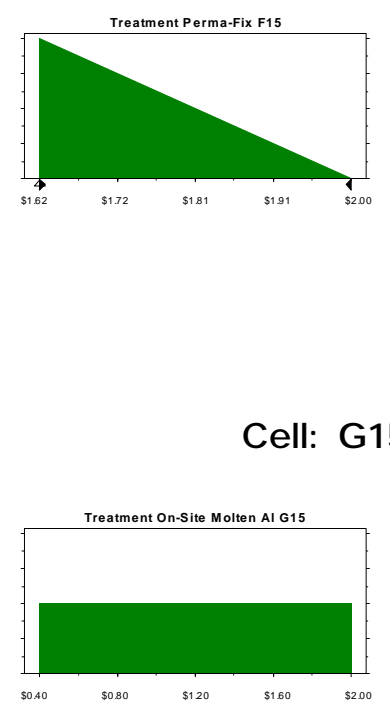

Mean value in simulation was $\$ 1.19$ 
Assumption: Treatment On-Site SW \& Solv Extract H15

Cell: H15

Triangular distribution with para meters:

Minimum

$\$ 0.27$

Likeliest

$\$ 0.50$

Maximum

$\$ 1.00$

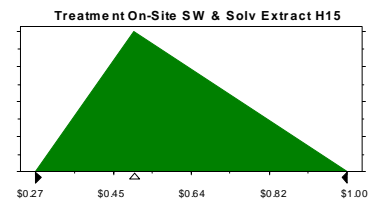

Selected range is from $\$ 0.27$ to $\$ 1.00$

Mean value in simulation was $\$ 0.59$

Assumption: Molten Al \% to landfill

Cell: G23

Uniform distribution with parameters: Minimum

Maximum

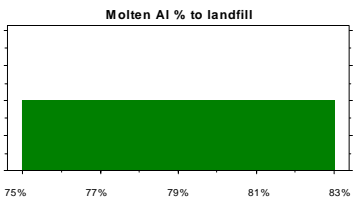

Mean value in simulation was $79 \%$

Assumption: Storage On-Site @ Plant 1

Cell: I14

Triangular distribution with parameters:

$\begin{array}{ll}\text { Minimum } & \$ 19.00 \\ \text { Likeliest } & \$ 23.00 \\ \text { Maximum } & \$ 27.60\end{array}$

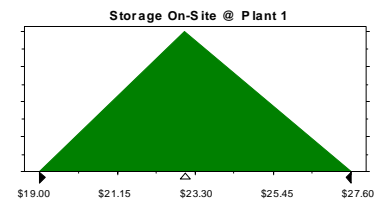

Selected range is from $\$ 19.00$ to $\$ 27.60$

Mean value in simulation was $\$ 23.45$

\section{Assumption: Storage Off Site @ Plant 2}

Cell: J14

Triangular distribution with pa ra meters:

Minimum

$\$ 22.00$

Likeliest

$\$ 27.50$

Maximum

$\$ 33.00$

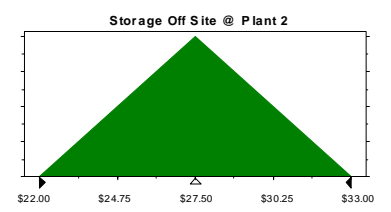

Selected range is from $\$ 22.00$ to $\$ 33.00$

Mean value in simulation was $\$ 27.44$ 
Assumption: Storage Off-Site, Out-of-State K14

Cell: K14

Triangular distribution with parameters: Minimum $\$ 10.00$

Likeliest $\$ 20.00$

Maximum

$\$ 22.00$

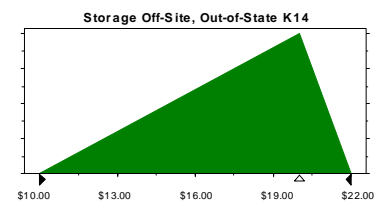

Selected range is from $\$ 10.00$ to $\$ 22.00$

Mean value in simulation was $\$ 17.40$

\section{Assumption: ATG Volume Change}

Cell: C27

Uniform distribution with parameters: Minimum

Maximum

Mean value in simulation was $70 \%$

\section{Assumption: WCS Volume Change}

Cell: D27

Uniform distribution with parameters:

Minimum

$113 \%$

Maximum

$138 \%$

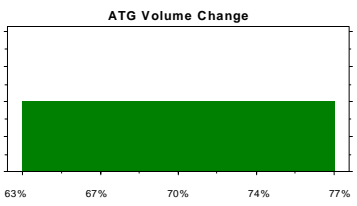

hange

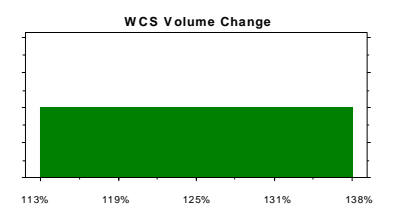

Mean value in simulation was $125 \%$

\section{Assumption: M\&EC Volume Change}

Cell: E27

Uniform distribution with parameters:

Minimum

$130 \%$

Maximum

$150 \%$

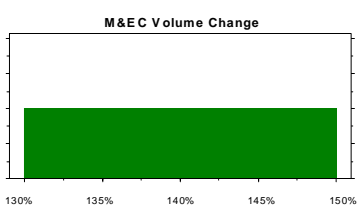

Mean value in simulation was $140 \%$ 
Assumption: Perma-Fix Volume Change

Uniform distribution with parameters:

$\begin{array}{ll}\text { Minimum } & 130 \% \\ \text { Maximum } & 150 \%\end{array}$

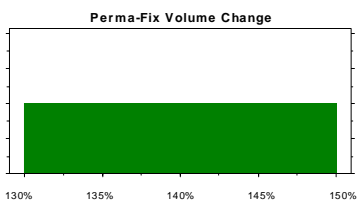

Mean value in simulation was $140 \%$

\section{Assumption: Molten Al Volume Change}

\section{Cell: G27}

Uniform distribution with parameters: Minimum

Maximum

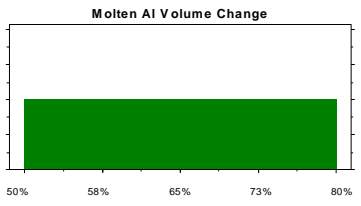

Mean value in simulation was $66 \%$

\section{Assumption: Soil Wash \& SV Volume Change}

Uniform distribution with parameters:

Minimum

$100 \%$

Maximum

$110 \%$

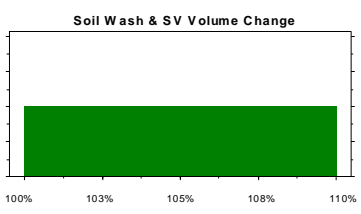

Mean value in simulation was $105 \%$

End of Assumptions 


\title{
Uncertainty Analysis for FMP
}

\author{
Crystal Ball Report \\ Simulation started on 8/29/00 at 16:33:28 \\ Simulation stopped on 8/29/00 at 16:33:45
}

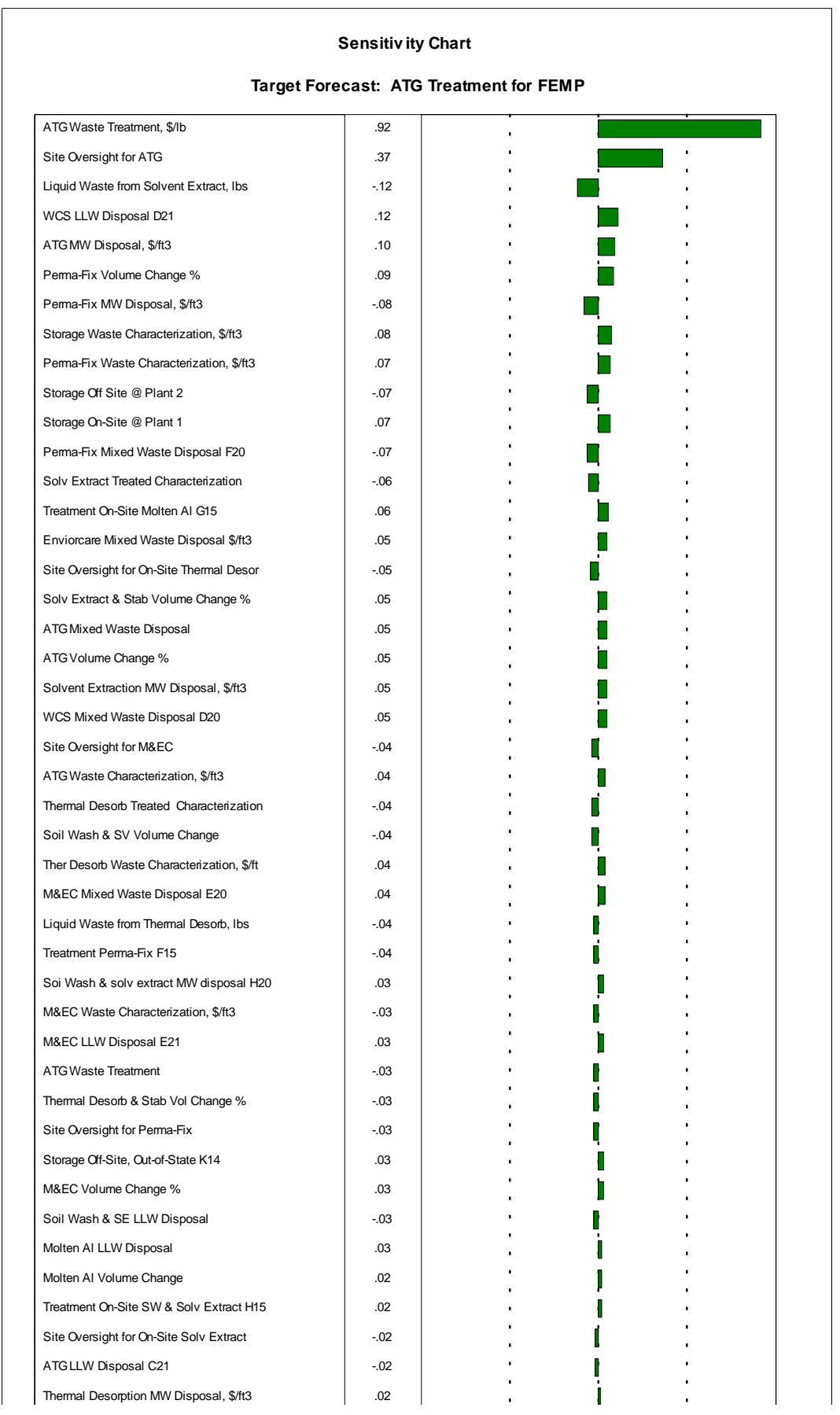


Uncertainty Analysis for FEMP

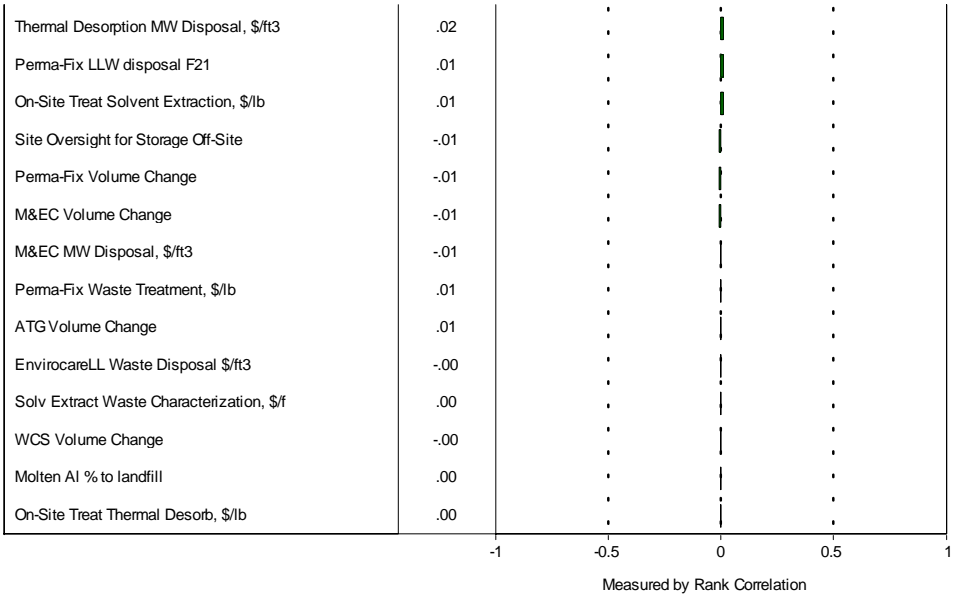


Forecast ATG Treatment for FMP

Summary:

Certa inty Level is $80.00 \%$

Certainty Range is from $\$ 1,986,417$ to $\$ 2,225,032$ Dollars

Display Range is from $\$ 1,900,000$ to $\$ 2,350,000$ Dollars

Entire Range is from $\$ 1,918,089$ to $\$ 2,308,310$ Dollars

After 500 Trials, the Std. Error of the Mean is $\$ 3,972$

Sta tistic S:

Trials

Value

Mean

500

Median

$\$ 2,112,222$

Mode

$\$ 2,113,582$

Standard Deviation

$\$ 88,822$

Variance

$\$ 7,889,283,722$

Skewness

Kurtosis

Coeff. of Variability

0.04

Range Minimum

$\$ 1,918,089$

Range Maximum

$\$ 2,308,310$

Range Width

$\$ 390,222$

Mean Std. Error

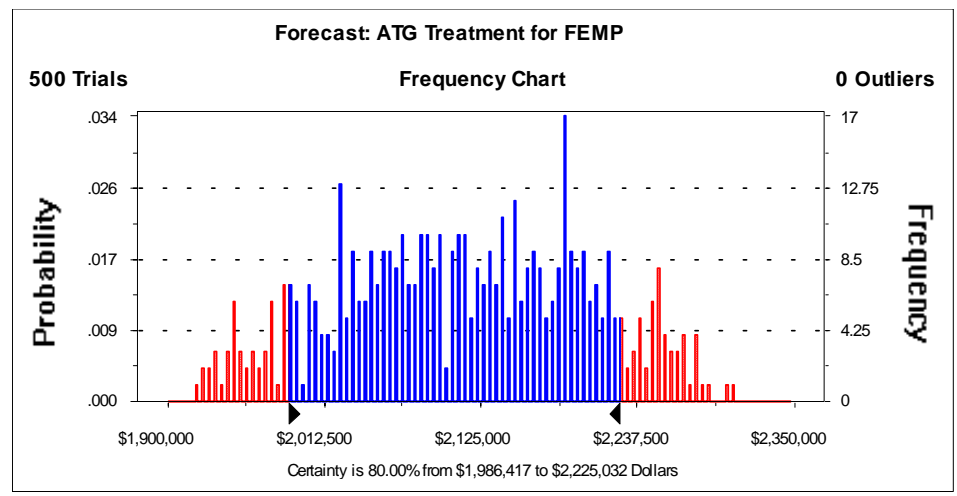


Forecast ATG Treatment for FEMP (contd)

Cell: B35

Percentiles:

\begin{tabular}{r} 
Percentile \\
\hline $0 \%$ \\
$10 \%$ \\
$20 \%$ \\
$30 \%$ \\
$40 \%$ \\
$50 \%$ \\
$60 \%$ \\
$70 \%$ \\
$80 \%$ \\
$90 \%$ \\
$100 \%$
\end{tabular}

Dollars

$\$ 1,918,089$

$\$ 1,989,207$

$\$ 2,030,125$

$\$ 2,059,084$

$\$ 2,085,702$

$\$ 2,113,582$

$\$ 2,141,953$

$\$ 2,168,986$

$\$ 2,194,784$

$\$ 2,228,004$

$\$ 2,308,310$

End of Forecast 
Forecast BSContract Treatment @ M\&EC for FMP

Summary:

Certa inty Level is $80.00 \%$

Certainty Range is from $\$ 845,655$ to $\$ 941,409$ Dollars

Display Range is from $\$ 800,000$ to $\$ 1,000,000$ Dollars

Entire Range is from $\$ 811,920$ to $\$ 977,273$ Dollars

After 500 Trials, the Std. Error of the Mean is $\$ 1,618$

$\begin{array}{lr}\text { Statistic s: } & \text { Value } \\ \text { Trials } & 500 \\ \text { Mean } & \$ 895,350 \\ \text { Median } & \$ 895,473 \\ \text { Mode } & --- \\ \text { Standard Deviation } & \$ 36,186 \\ \text { Variance } & \$ 1,309,393,011 \\ \text { Skewness } & -0.05 \\ \text { Kurtosis } & 2.20 \\ \text { Coeff. of Variability } & 0.04 \\ \text { Range Minimum } & \$ 811,920 \\ \text { Range Maximum } & \$ 977,273 \\ \text { Range Width } & \$ 165,353 \\ \text { Mean Std. Error } & \$ 1,618.27\end{array}$

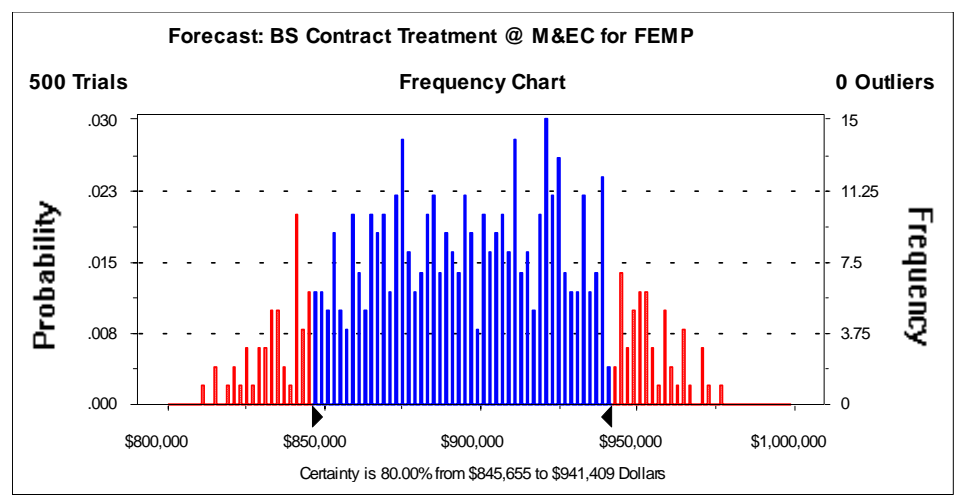


Forecast BS Contract Treatment @ M\&EC for FMP (cont'd)

\section{Cell: C35}

Percentiles:

Percentile
$0 \%$
$10 \%$
$20 \%$
$30 \%$
$40 \%$
$50 \%$
$60 \%$
$70 \%$
$80 \%$
$90 \%$
$100 \%$

Dollars

$\$ 811,920$

$\$ 845,746$

$\$ 861,111$

$\$ 873,436$

$\$ 884,365$

$\$ 895,473$

$\$ 907,491$

$\$ 918,806$

$\$ 928,006$

$\$ 942,903$

$\$ 977,273$

End of Forecast 
Forec ast Treatment @ Pema-fix for FMP

Summary:

Certa inty Level is $80.00 \%$

Certa inty Range is from $\$ 895,746$ to $\$ 1,003,015$ Dollars

Display Range is from $\$ 850,000$ to $\$ 1,075,000$ Dollars

Entire Range is from $\$ 859,448$ to $\$ 1,069,514$ Dollars

After 500 Trials, the Std. Error of the Mean is $\$ 1,851$

Sta tistic S:

Trials

Value

Mean

500

Median

$\$ 954,504$

Mode

$\$ 955,981$

Standard Deviation

$\$ 41,386$

Variance

$\$ 1,712,792,439$

Skewness

0.06

Kurtosis

2.60

Coeff. of Variability

0.04

Range Minimum

$\$ 859,448$

Range Maximum

$\$ 1,069,514$

Range Width

$\$ 210,066$

Mean Std. Error

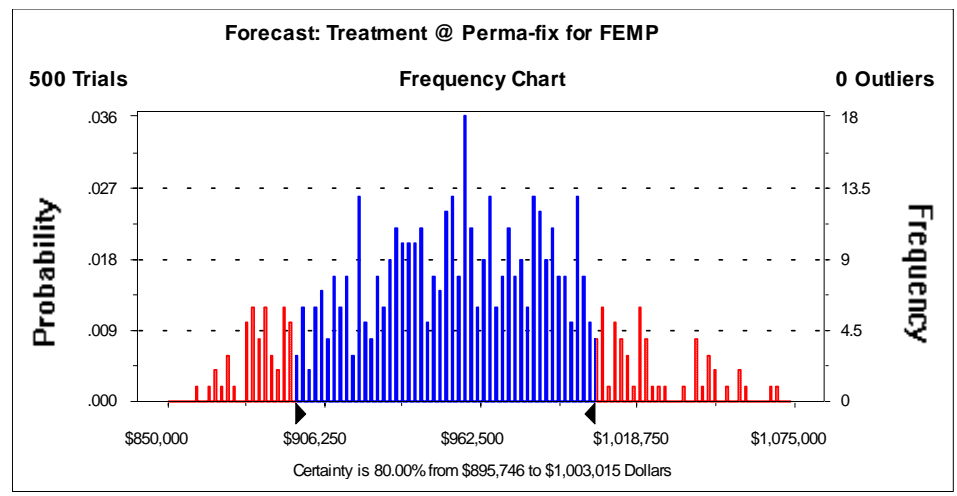


Forecast Treatment @ Pema-fix for FMP (cont'd)

\section{Cell: D35}

Percentiles:

Percentile
$0 \%$
$10 \%$
$20 \%$
$30 \%$
$40 \%$
$50 \%$
$60 \%$
$70 \%$
$80 \%$
$90 \%$
$100 \%$

Dollars

$\$ 859,448$

$\$ 897,357$

$\$ 917,542$

$\$ 932,512$

$\$ 943,503$

$\$ 955,981$

$\$ 966,131$

$\$ 978,755$

$\$ 989,694$

$\$ 1,004,212$

$\$ 1,069,514$

End of Forecast 
Forecast FMP Treatment On-Site Using Solv Extrac

Summary:

Certa inty Level is $80.00 \%$

Certa inty Range is from $\$ 2,925,396$ to $\$ 3,819,328$

Display Range is from $\$ 2,500,000$ to $\$ 4,250,000$

Entire Range is from $\$ 2,652,361$ to $\$ 4,232,734$

After 500 Trials, the Std. Error of the Mean is $\$ 15,161$

Sta tistic s:

Trials

Value

Mean

500

Median

$\$ 3,357,852$

Mode

$\$ 3,349,819$

Standard Deviation

$\$ 339,002$

Variance

$1 \mathrm{E}+11$

Skewness

0.13

Kurtosis

2.30

Coeff. of Variability

0.10

Range Minimum

$\$ 2,652,361$

Range Maximum

$\$ 4,232,734$

Range Width

$\$ 1,580,373$

Mean Std. Error

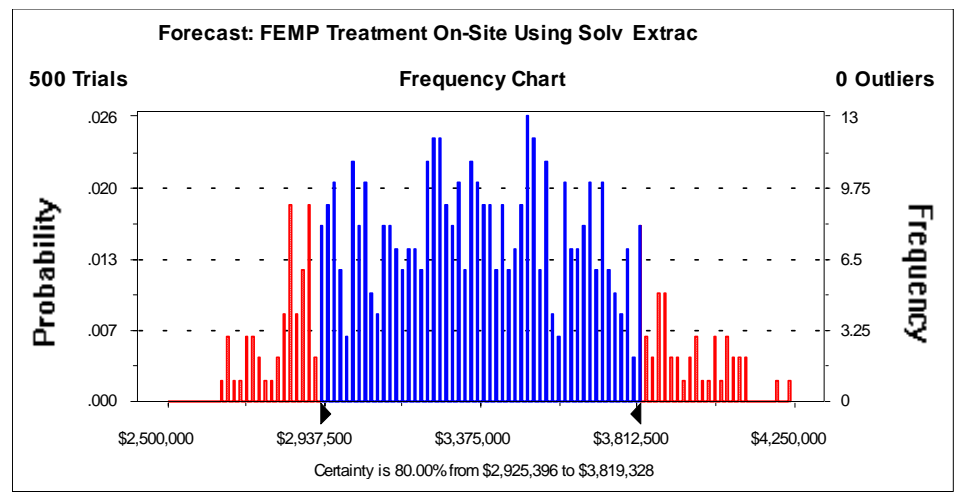


Forecast FMP Treatment On-Site Using Solv Extrac (contd)

\section{Cell: E35}

Percentiles:

Percentile
$0 \%$
$10 \%$
$20 \%$
$30 \%$
$40 \%$
$50 \%$
$60 \%$
$70 \%$
$80 \%$
$90 \%$
$100 \%$

Value

$\$ 2,652,361$

$\$ 2,902,050$

$\$ 3,027,675$

$\$ 3,147,848$

$\$ 3,255,540$

$\$ 3,349,819$

$\$ 3,454,126$

$\$ 3,549,599$

$\$ 3,671,285$

$\$ 3,808,953$

$\$ 4,232,734$

End of Forecast 
Forecast FMPTreatment On-Site Using Themal Des

Summary:

Certa inty Level is $80.00 \%$

Certa inty Range is from $\$ 3,003,381$ to $\$ 3,854,340$

Display Range is from $\$ 2,500,000$ to $\$ 4,500,000$

Entire Range is from $\$ 2,746,804$ to $\$ 4,288,844$

After 500 Trials, the Std. Error of the Mean is $\$ 14,447$

$\begin{array}{lr}\text { Statistic s: } & \text { Value } \\ \text { Trials } & 500 \\ \text { Mean } & \$ 3,447,661 \\ \text { Median } & \$ 3,455,096 \\ \text { Mode } & --- \\ \text { Standard Deviation } & \$ 323,052 \\ \text { Variance } & 1 \mathrm{E}+11 \\ \text { Skewness } & 0.08 \\ \text { Kurtosis } & 2.27 \\ \text { Coeff. of Variability } & 0.09 \\ \text { Range Minimum } & \$ 2,746,804 \\ \text { Range Maximum } & \$ 4,288,844 \\ \text { Range Width } & \$ 1,542,039 \\ \text { Mean Std. Error } & \$ 14,447.31\end{array}$

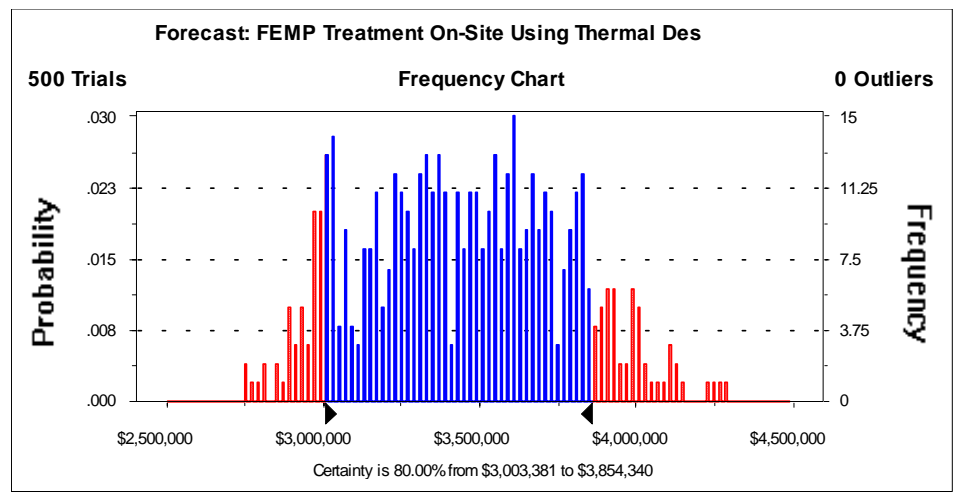


Forecast FMP Treatment On-Site Using Thermal Des (contd)

\section{Cell: F35}

Percentiles:

Percentile
$0 \%$
$10 \%$
$20 \%$
$30 \%$
$40 \%$
$50 \%$
$60 \%$
$70 \%$
$80 \%$
$90 \%$
$100 \%$

$\underline{\text { Value }}$

$\$ 2,746,804$

$\$ 3,006,032$

$\$ 3,139,357$

$\$ 3,249,896$

$\$ 3,343,189$

$\$ 3,455,096$

$\$ 3,543,308$

$\$ 3,638,748$

$\$ 3,736,686$

$\$ 3,862,183$

$\$ 4,288,844$

End of Forecast 
Forecast FMP Waste Storage Off-Site for 5 Years

Summary:

Certa inty Level is $80.00 \%$

Certa inty Range is from $\$ 286,455$ to $\$ 319,626$ Dollars

Display Range is from $\$ 280,000$ to $\$ 330,000$ Dollars

Entire Range is from $\$ 281,801$ to $\$ 325,511$ Dollars

After 500 Trials, the Std. Error of the Mean is $\$ 524$

$\begin{array}{lr}\text { Statistic s: } & \text { Value } \\ \text { Trials } & 500 \\ \text { Mean } & \$ 302,219 \\ \text { Median } & \$ 301,923 \\ \text { Mode } & --- \\ \text { Standard Deviation } & \$ 11,717 \\ \text { Variance } & \$ 137,286,588 \\ \text { Skewness } & 0.11 \\ \text { Kurtosis } & 1.92 \\ \text { Coeff. of Variability } & 0.04 \\ \text { Range Minimum } & \$ 281,801 \\ \text { Range Maximum } & \$ 325,511 \\ \text { Range Width } & \$ 43,710 \\ \text { Mean Std. Error } & \$ 524.00\end{array}$

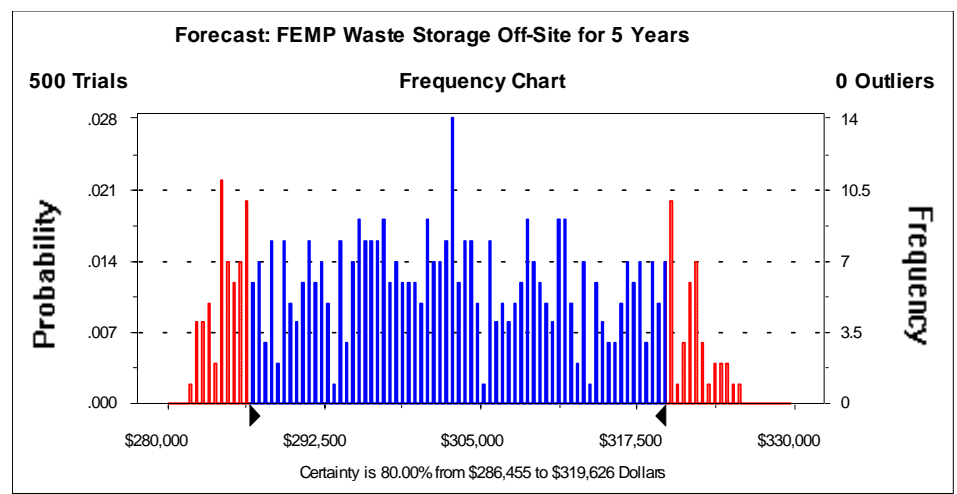


Forecast FMP Waste Storage Off-Site for 5 Years (cont'd)

\section{Cell: G35}

Percentiles:

Percentile
$0 \%$
$10 \%$
$20 \%$
$30 \%$
$40 \%$
$50 \%$
$60 \%$
$70 \%$
$80 \%$
$90 \%$
$100 \%$

Dollars

$\$ 281,801$

$\$ 286,057$

$\$ 290,269$

$\$ 294,785$

$\$ 298,092$

$\$ 301,923$

$\$ 304,765$

$\$ 309,393$

$\$ 314,154$

$\$ 319,012$

$\$ 325,511$

End of Forecast 


\section{Assumptions}

Assumption: ATG MWDisposal, \$/ft3

Cell: B20

Triangular distribution with parameters:

Minimum

Likeliest

$\$ 22.50$

Maximum
$\$ 25.00$

$\$ 35.00$

Selected range is from $\$ 22.50$ to $\$ 35.00$

Mean value in simulation was $\$ 27.55$

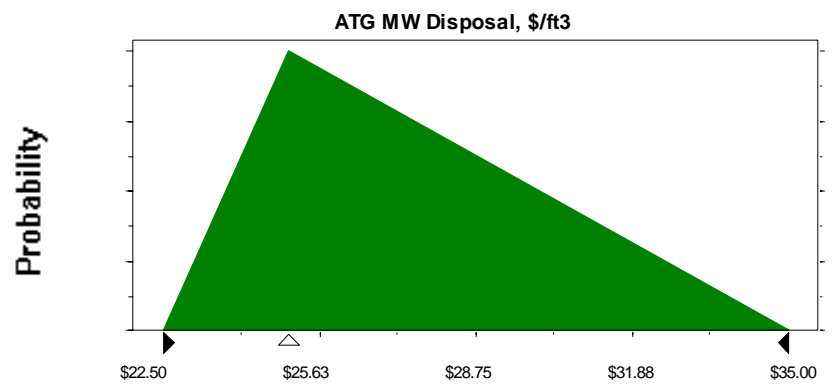

Assumption: M\&EC MWDisposal, \$/ft3

Triangular distribution with pa ra meters:

$\begin{array}{ll}\text { Minimum } & \$ 22.50 \\ \text { Likeliest } & \$ 25.00 \\ \text { Maximum } & \$ 35.00\end{array}$

Selected range is from $\$ 22.50$ to $\$ 35.00$

Mean value in simulation was $\$ 27.45$ 


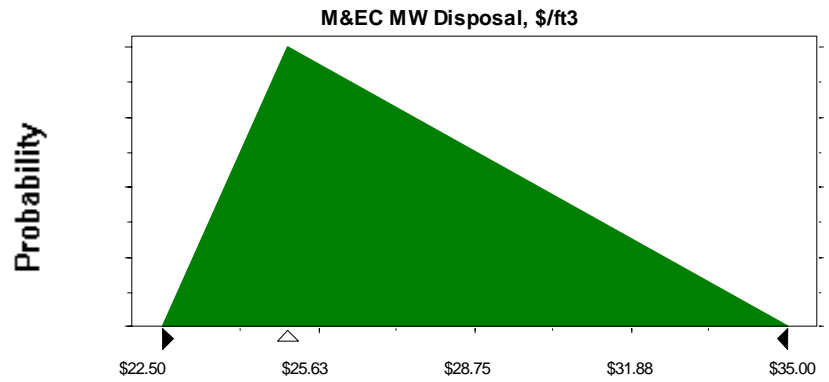

Assumption: Perma-Fix MW Disposal, \$/ft3

Triangular distribution with pa ra meters:

Minimum

$\$ 22.50$

Likeliest

$\$ 25.00$

Maximum

$\$ 35.00$

Selected range is from $\$ 22.50$ to $\$ 35.00$

Mean value in simulation was $\$ 27.66$

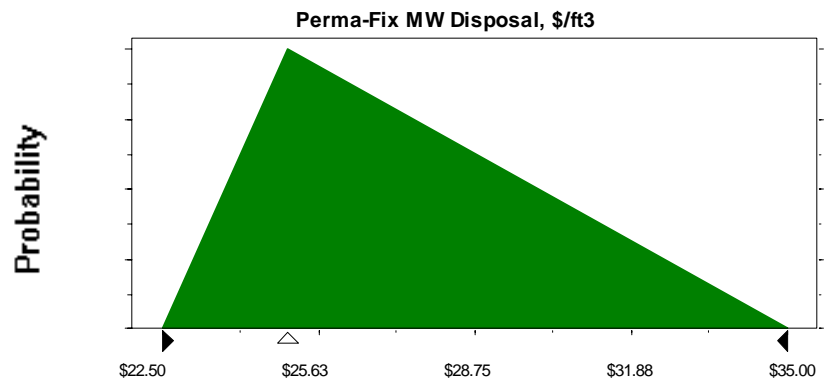


Assumption: Solvent Extraction MW Disposal, \$/ft3

Cell: E20

Triangular distribution with pa ra meters:

$\begin{array}{ll}\text { Minimum } & \$ 22.50 \\ \text { Lkeliest } & \$ 25.00 \\ \text { Maximum } & \$ 35.00\end{array}$

Selected range is from $\$ 22.50$ to $\$ 35.00$

Mean value in simulation was $\$ 27.56$

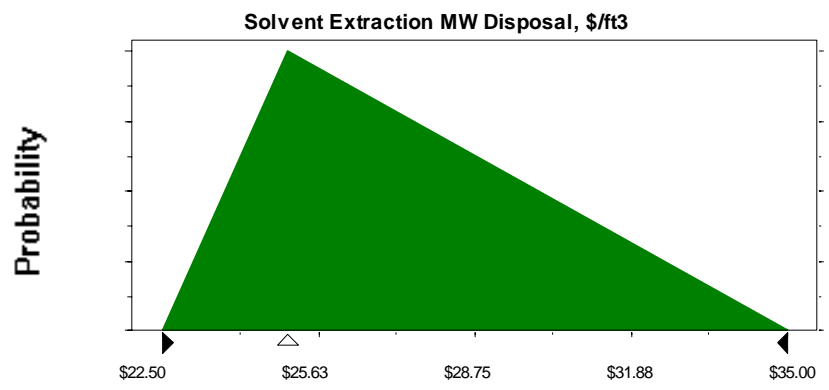

Assumption: Themal Desorption MW Disposal, \$/ ft3

Triangula r distribution with parameters:

Minimum

$\$ 22.50$

Likeliest

$\$ 25.00$

Maximum

$\$ 35.00$

Selected range is from $\$ 22.50$ to $\$ 35.00$

Mean value in simulation was $\$ 27.63$ 


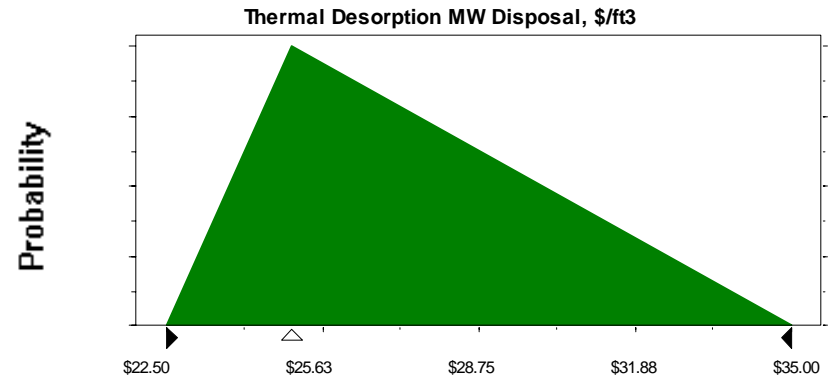

Assumption: ATG Waste Treatment, $\$ /$ lb

Uniform distribution with parameters:

Minimum

Maximum

Mean value in simulation was $\$ 7.42$

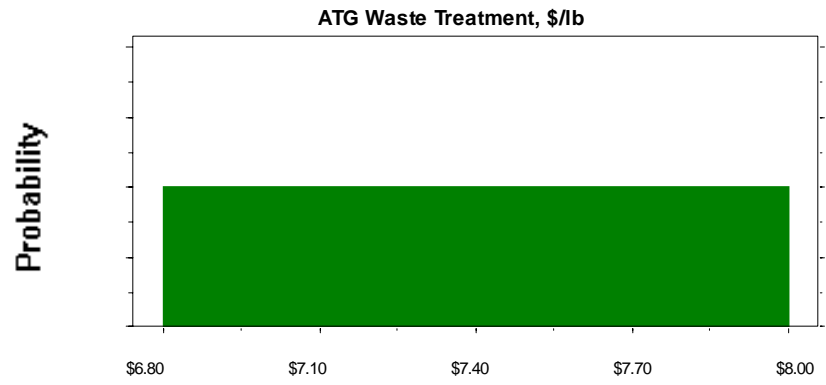


Assumption: Perma-Fix Waste Treatment, \$/lb

Triangular distribution with pa ra meters:

$\begin{array}{ll}\text { Minimum } & \$ 1.62 \\ \text { Likeliest } & \$ 1.62 \\ \text { Maximum } & \$ 2.00\end{array}$

Selected range is from $\$ 1.62$ to $\$ 2.00$

Mean value in simulation was $\$ 1.74$

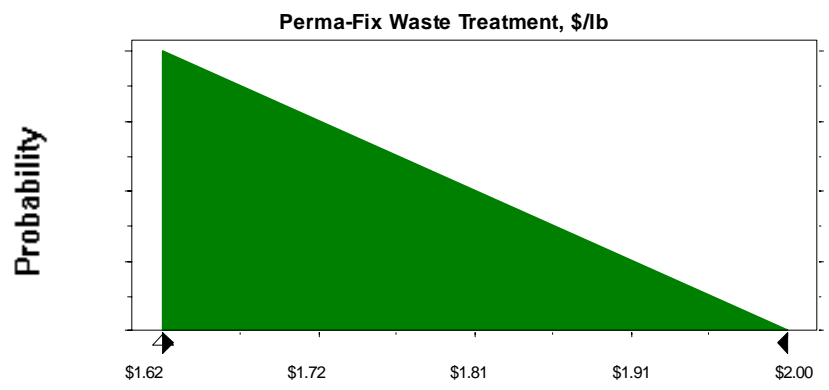

Assumption: ATG Volume Change \%

Uniform distribution with parameters:

Minimum

$63 \%$

Maximum

$77 \%$

Mean value in simulation was $70 \%$ 


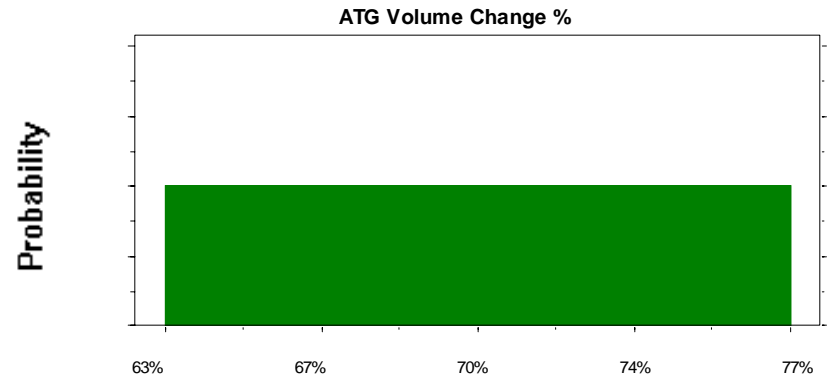

Assumption: M\&EC Volume Change \%

Uniform distribution with parameters:

Minimum

Maximum

Mean value in simulation was $140 \%$

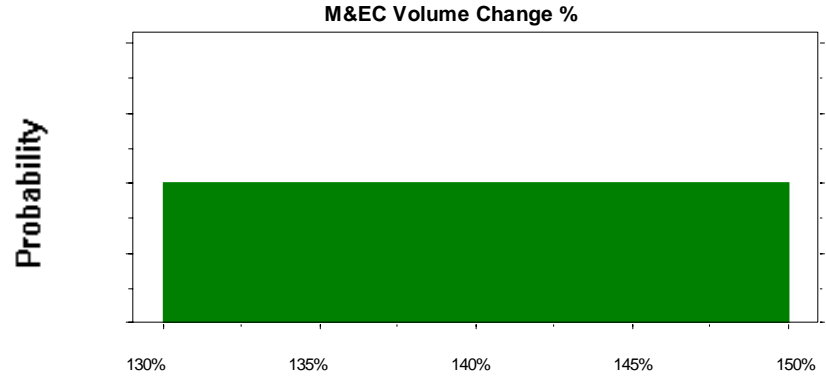


Assumption: Pema-Fix Volume Change \%

Uniform distribution with parameters:

$\begin{array}{ll}\text { Minimum } & 130 \% \\ \text { Maximum } & 150 \%\end{array}$

Mean value in simulation was $140 \%$

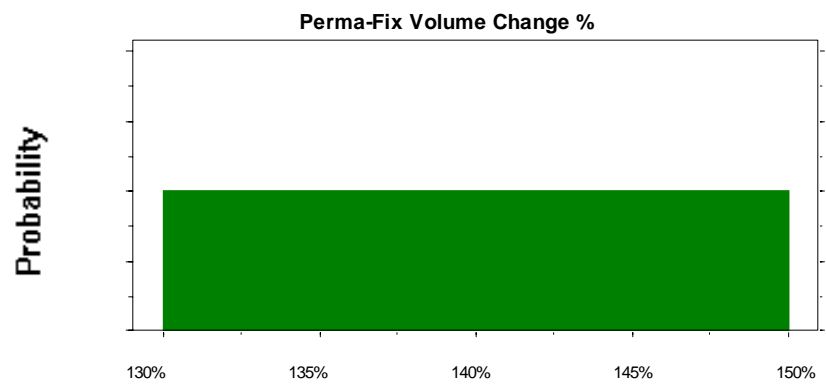

Assumption: Solv Extract \& Stab Volume Change \%

Uniform distribution with parameters:

Minimum

$130 \%$

Maximum

$150 \%$

Mean value in simulation was $140 \%$ 


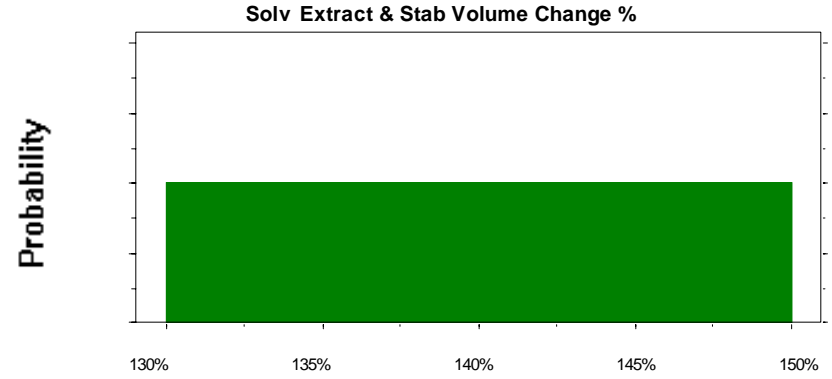

Assumption: Themal Desorb \& Stab Vol Change \%

Uniform distribution with parameters:

Minimum

Maximum

Mean value in simulation was $140 \%$
$130 \%$

$150 \%$

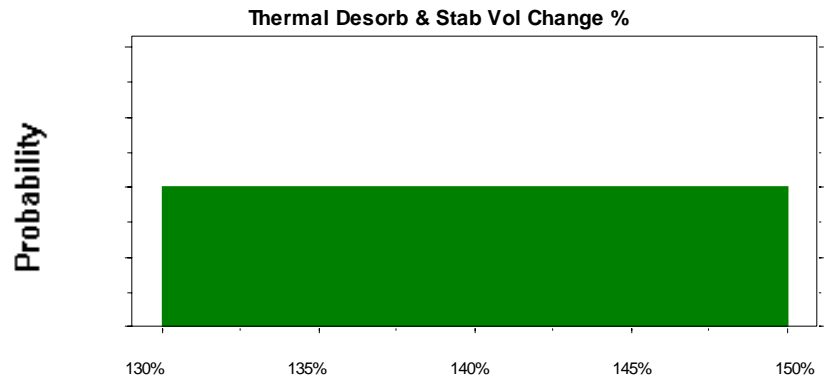


Assumption: ATG Waste Characterization, \$/ft3

Uniform distribution with parameters:

$\begin{array}{ll}\text { Minimum } & \$ 8.10 \\ \text { Maximum } & \$ 9.90\end{array}$

Mean value in simulation was $\$ 9.01$

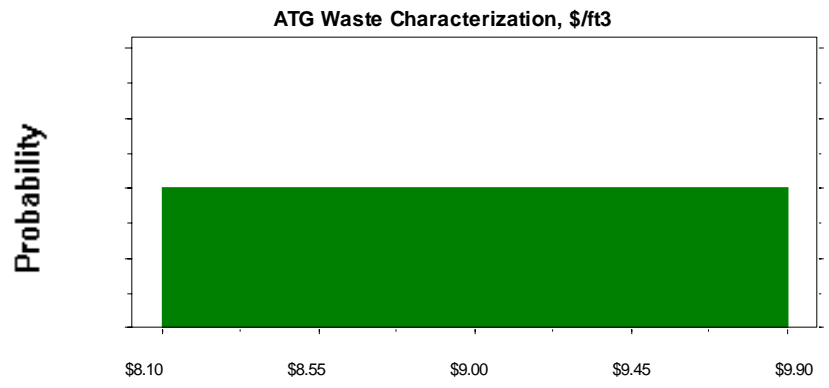

Assumption: M\&EC Waste Characterization, \$/ft3

Uniform distribution with parameters:

Minimum

$\$ 8.10$

Maximum

$\$ 9.90$

Mean value in simulation was $\$ 9.02$ 


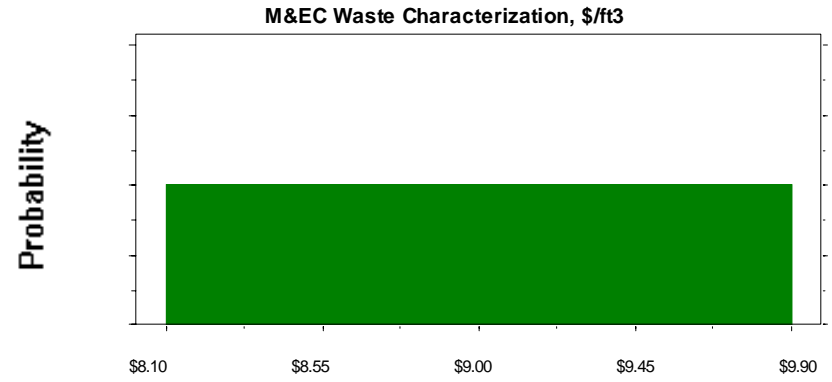

Assumption: Perma-Fix Waste Characterization, \$/ft3

Uniform distribution with parameters:

Minimum

Maximum

$\$ 8.10$

$\$ 9.90$

Mean value in simulation was $\$ 8.97$

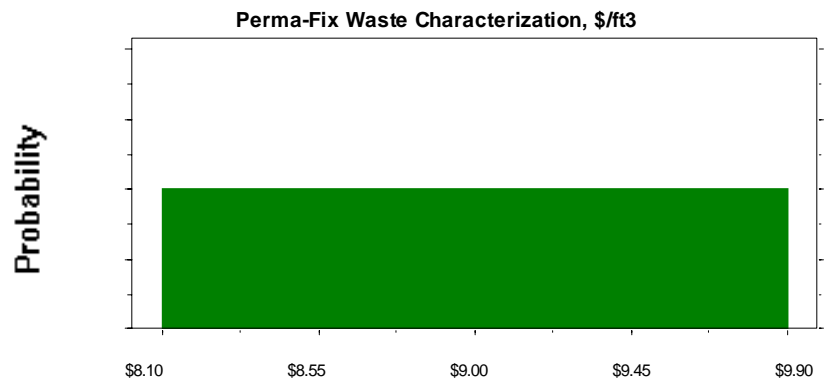


Assumption: Solv Extract Waste Characterization, \$/f

Uniform distribution with parameters:

$\begin{array}{ll}\text { Minimum } & \$ 8.10 \\ \text { Maximum } & \$ 9.90\end{array}$

Mean value in simulation was $\$ 8.99$

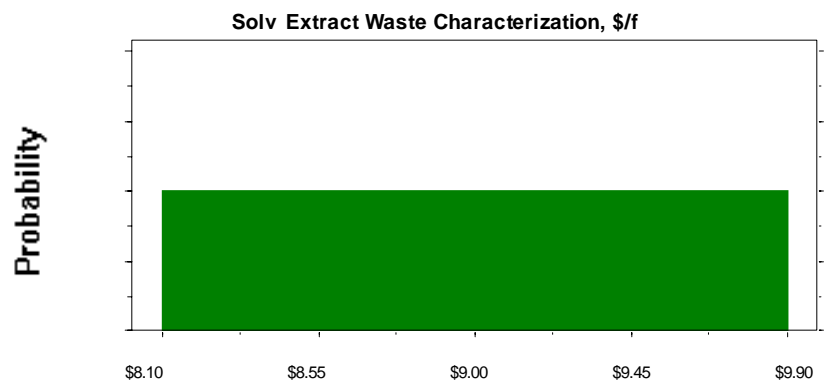

Assumption: Ther Desorb Waste Charac tenization, $\$ / \mathrm{ft}$

\section{Cell: F11}

Uniform distribution with parameters:

Minimum

$\$ 8.10$

Maximum

$\$ 9.90$

Mean value in simulation was $\$ 8.98$ 


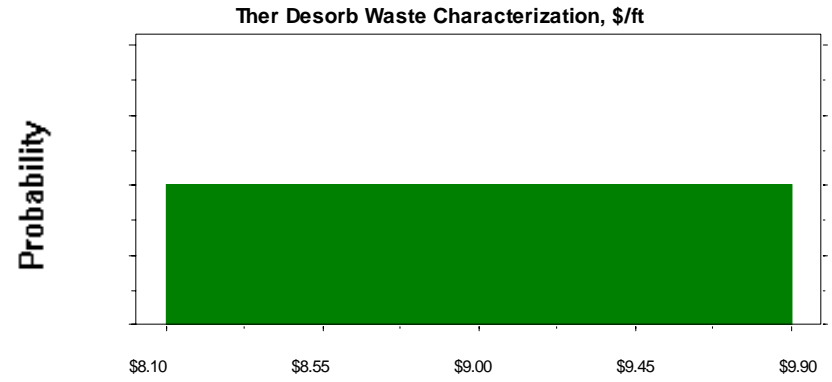

Assumption: Storage Waste Characterization, \$/ft3

Uniform distribution with parameters:

Minimum

Maximum

Mean value in simulation was $\$ 9.01$

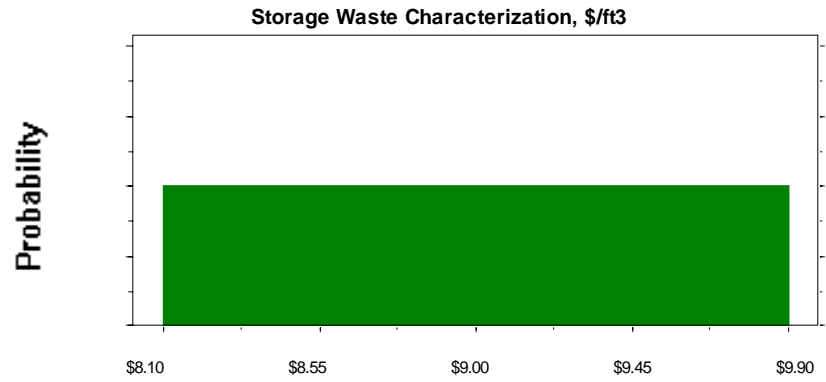


Assumption: Solv Extract Treated Charac terization

Uniform distribution with parameters:

$\begin{array}{ll}\text { Minimum } & \$ 8.10 \\ \text { Maximum } & \$ 9.90\end{array}$

Mean value in simulation was $\$ 9.07$

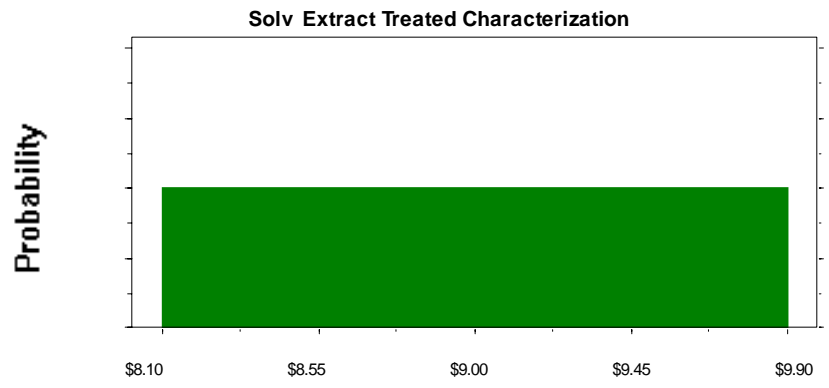

Assumption: Themal Desorb Treated Characterization

\section{Cell: F16}

Uniform distribution with parameters:

Minimum

$\$ 8.10$

Maximum

$\$ 9.90$

Mean value in simulation was $\$ 8.99$ 


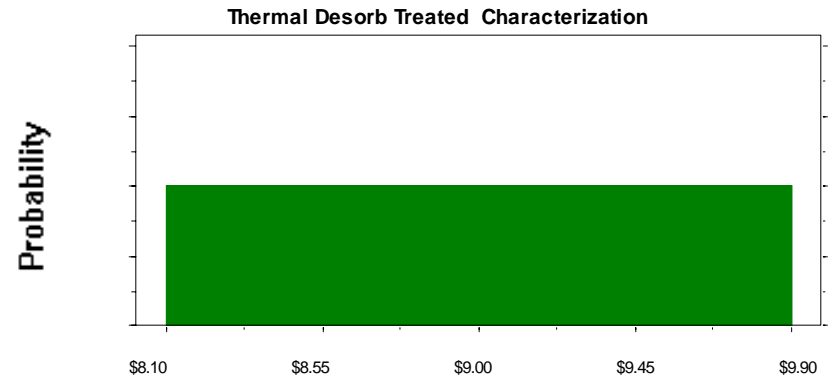

Assumption: On-Site Treat Themal Desorb, \$/lb

Triangular distribution with pa rameters:

Minimum

$\$ 5.00$

Likeliest

$\$ 6.00$

Maximum

$\$ 7.00$

Selected range is from $\$ 5.00$ to $\$ 7.00$

Mean value in simulation was $\$ 6.01$

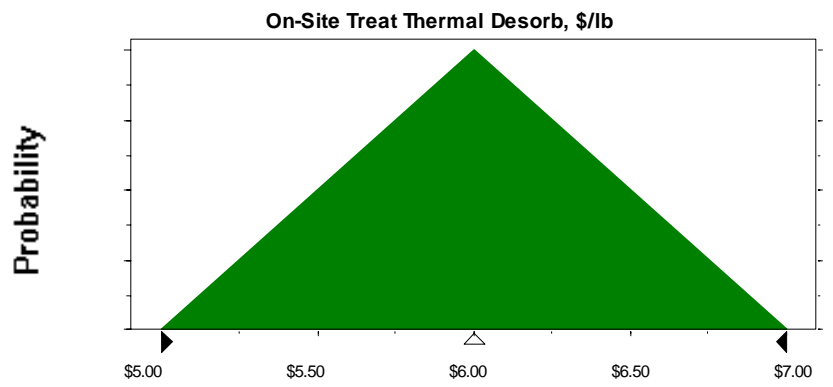


Assumption: On-Site Treat Solvent Extraction, $\$ / / b$

Triangular distribution with pa ra meters:

$\begin{array}{ll}\text { Minimum } & \$ 4.00 \\ \text { Likeliest } & \$ 5.00 \\ \text { Maximum } & \$ 6.00\end{array}$

Selected range is from $\$ 4.00$ to $\$ 6.00$

Mean value in simulation was $\$ 4.99$

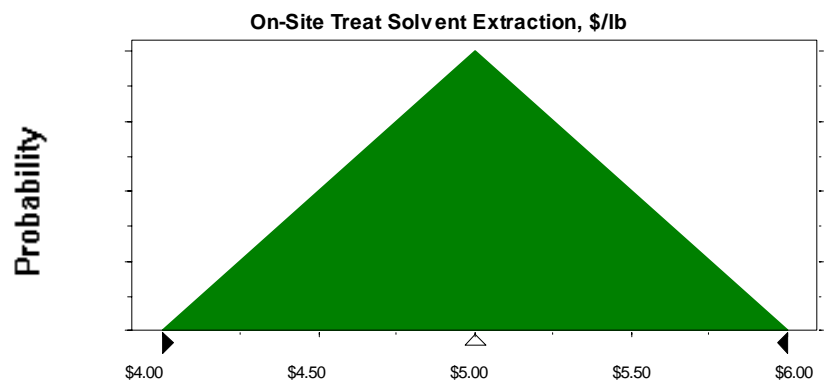

Assumption: Liquid Waste from Solvent Extract, lbs

Uniform distribution with parameters:

Minimum

$51,525.00$

Maximum

$62,975.00$

Mean value in simulation was $57,340.72$ 


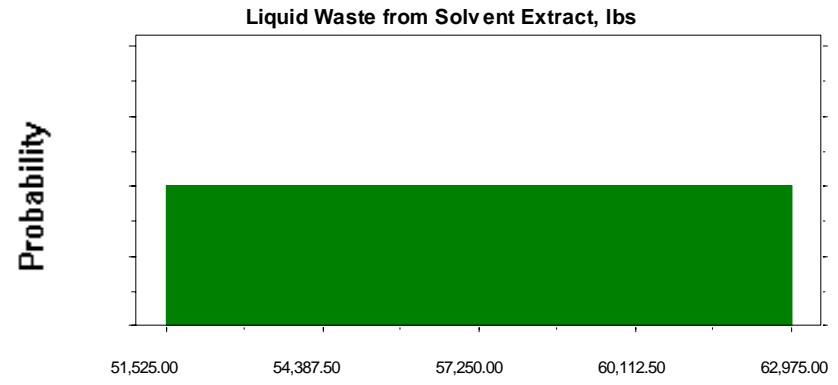

Assumption: Liquid Waste from Thermal Desorb, lbs

Uniform distribution with parameters:

Minimum

Maximum

Mean value in simulation was $11,433.88$

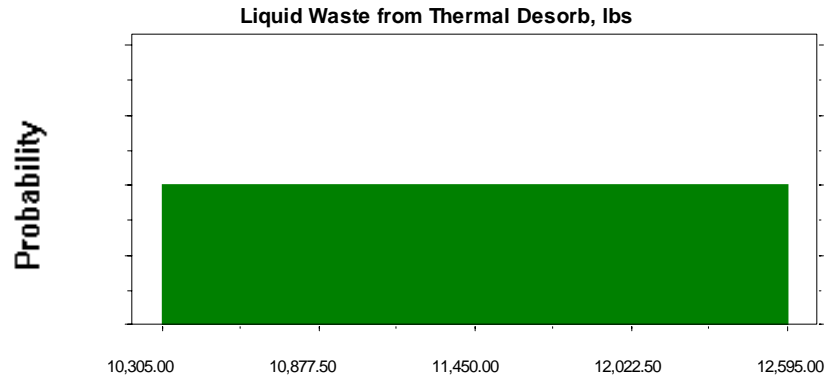


Assumption: Site Oversight for ATG

Uniform distribution with parameters:

$\begin{array}{lr}\text { Minimum } & 5 \% \\ \text { Maximum } & 20 \%\end{array}$

Mean value in simulation was $13 \%$

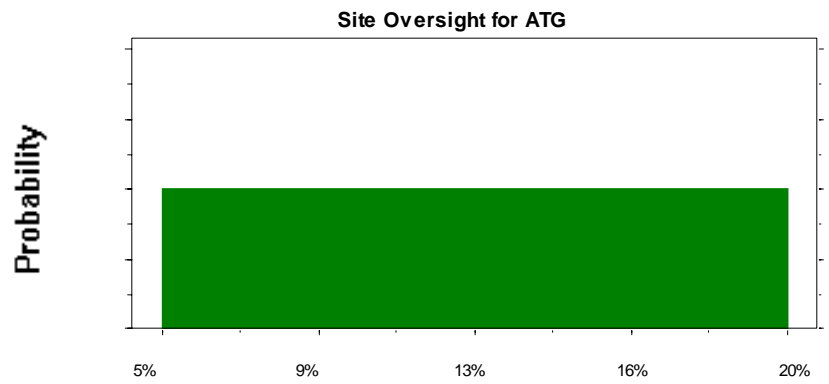

Assumption: Site Oversight for M\&EC

Uniform distribution with parameters:

Minimum

$5 \%$

Maximum

$20 \%$

Mean value in simulation was $13 \%$ 


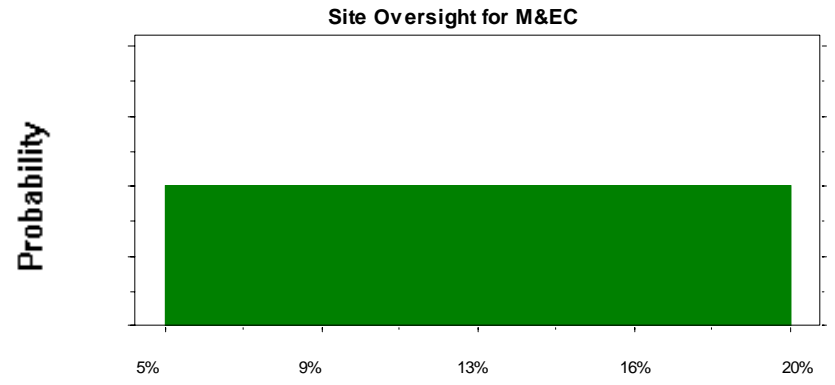

Assumption: Site Oversight for Perma-Fix

Uniform distribution with parameters:

Minimum

Maximum

Mean value in simulation was $13 \%$

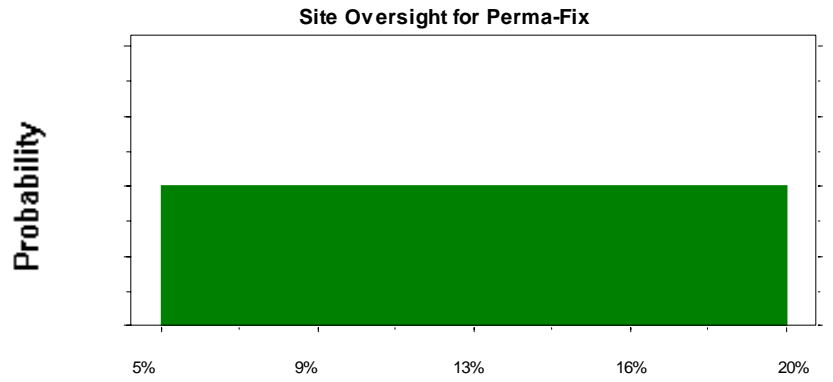


Assumption: Site Oversight for Storage Off-Site

Uniform distribution with parameters:

$\begin{array}{lr}\text { Minimum } & 5 \% \\ \text { Maximum } & 20 \%\end{array}$

Mean value in simulation was $12 \%$

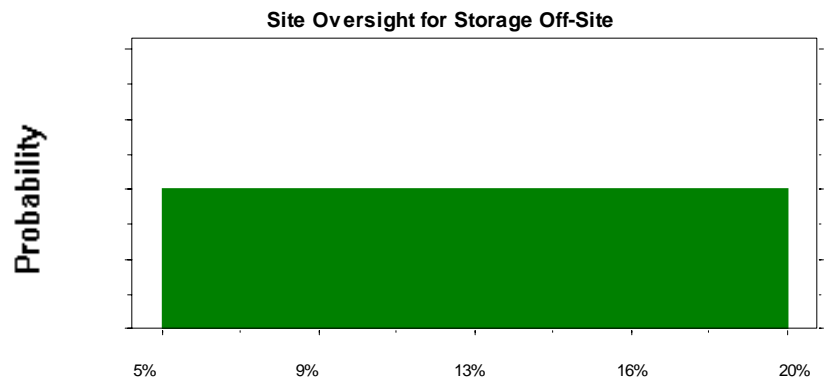

Assumption: Site Oversight for On-Site Solv Extract

\section{Cell: E26}

Uniform distribution with parameters:

Minimum

$50 \%$

Maximum

$100 \%$

Mean value in simulation was $75 \%$ 


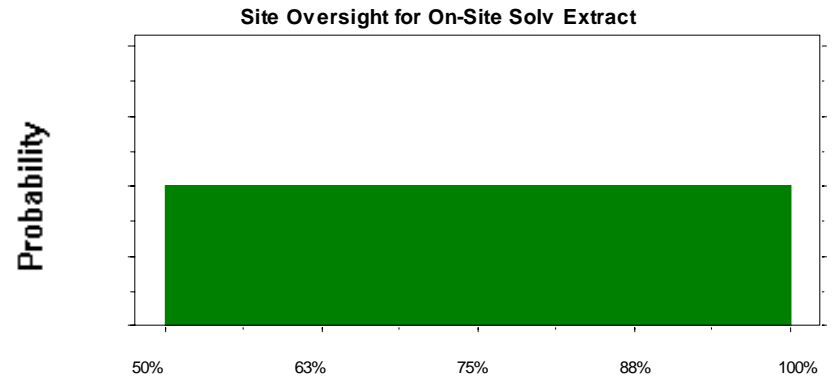

End of Assumptions 
ORNL/TM-2000/254

\title{
DISTRIBUTION
}

\author{
Internal
}

1. J. M. Begovich

11-13. C. I. Moser

2. J. B. Berry

3. M. J. Gresalfi

4. W. H. Hermes

5. J. R. Hightower

6-10. M. I. Morris

\author{
14-28. K. L. Yuracko \\ 29. Laboratory Records - RC \\ 30. Central Research Library \\ 31-32. Laboratory Records - OSTI
}

\section{External}

33-36. Scott Altmayer, Earthline Technologies, P.O. Box 579, Ashtabula, OH 44005-0579

37. Tom Baillieul, U.S. Department of Energy, Columbus Environmental Management, 555 Metro Place North, Suite 415, Dublin, OH 43017

38-41. Helen Belencan, U.S. Department of Energy, EM-22, Cloverleaf Building, 19901 Germantown Road, Germantown, MD 20874

42. Ward Best, U.S. Department of Energy, Ohio Field Office, P.O. Box 3020, Miamisburg, OH 45343-3020

43. Tony Bindokas, U.S. Department of Energy, Chicago Operations Office, 9800 South Cass Avenue, Building 201, EPG, Argonne, IL 60439

44. Steve Bossart, U.S. Department of Energy, National Energy Technology Laboratory, Deactivation and Decommissioning Focus Area, P.O. Box 80, 3610 Collins Ferry Road, Morgantown, WV 26505

45. Dennis Cook, Fluor Fernald, Inc., P.O. Box 538704, Cincinnati, OH 45253-8704

46. John Corey, 212 Lakeside Drive, Aiken, SC 28903

47. Jack Craig, U.S. Department of Energy, Ohio Field Office, P.O. Box 3020, Miamisburg, OH 45343-3020

48. John DeGregory, U.S. Department of Energy, EM-54, Cloverleaf Building, 19901 Germantown Road, Germantown, MD 20874

49. Miles Dionisio, U.S. Department of Energy, Chicago Operations Office, 9800 South Cass Avenue, Building 201, EPG, Argonne, IL 60439

50. Joel Duling, Fluor Fernald, Inc., P.O. Box 538704, Cincinnati, OH 45253-8704

51-54. David Eaton, Idaho National Engineering and Environmental Laboratory, Mixed Waste Focus Area, P.O. Box 1625, Idaho Falls, ID 83415-3875

55. Jim Gambrell, U.S. Department of Energy, Miamisburg Environmental Management Project, P.O. Box 3020, Miamisburg, OH 45343-3020

56-58. John Ganz, U.S. Department of Energy, Ashtabula Environmental Management Project, 1800 East 21st Street, P.O. Box 579, Ashtabula, OH 44044

59. Ray Geimer, Kaiser-Hill, Rocky Flats Environmental Technology Site, 10808 Highway 93, Unit B, Bldg. T-130 J, Golden, CO 80403-8200

60. Geoff Gorsuch, U.S. Department of Energy, Ashtabula Environmental Management Project, 1800 East 21st Street, P.O. Box 579, Ashtabula, OH 44044 
61-70. Richard Govers, The Chamberlain Group, Ltd., 2200 Langhorne Road, Suite 201, Lynchburg, VA 24501

71. Jim Griffin, U.S. Department of Energy, Columbus Environmental Management Project Support, 555 Metro Place North, Suite 415, Dublin, OH 43017

72-76. Kent Hancock, U.S. Department of Energy, EM-22, Cloverleaf Building, 19901 Germantown Road, Germantown, MD 20874

77. Marian Heffner, Earthline Technologies, P.O. Box 579, Ashtabula, OH 44005-0579

78. Nicholas Hefty, Florida International University, Center for Engineering and Applied Science, 10555 West Flagler St., CEAS-2100, Miami, FL 33174

79. Jim Henderson, Earthline Technologies, P.O. Box 579, Ashtabula, OH 44005-0579

80. Karen Hooker, U.S. Department of Energy, Savannah River Site Office, Road 1, Bldg. 703-A, Aiken, SC 29802

81. Gary Huffman, U.S. Department of Energy, Rocky Flats Environmental Technology Site, 10808 Highway 93, Unit A, Golden, CO 80403-8200

82. Greg Hulet, Idaho National Engineering and Environmental Laboratory, Mixed Waste Focus Area, P.O. Box 1625, Idaho Falls, ID 83415-3875

83. John Kreuger, BWXTO, P.O. Box 3030, Miamisburg, OH 45343-3020

84. Michael Krstich, Environmental Management Solutions, Governor's Pointe, 4660 Duke Drive, Suite 300, Mason, OH 45040

85. Jeff Kulpa, Earthline Technologies, P.O. Box 579, Ashtabula, OH 44005-0579

86. Quon Kwan, Energetics, 7164 Columbia Gateway Drive, Columbia, MD 21046

87. Keely Lange, U.S. Department of Energy, EM-13, 5B-125, 1000 Independence Ave. SW, Washington, DC 20585

88. Steve Lopez, Idaho National Engineering and Environmental Laboratory, Environmental Technology and Integration, P.O. Box 1625, Idaho Falls, ID 83415-3875404

89. John Lum, U.S. Department of Energy, EM-22, Cloverleaf Building, 19901 Germantown Road, Germantown, MD 20874

90. Vince Maio, Idaho National Engineering and Environmental Laboratory, Mixed Waste Focus Area, P.O. Box 1625, Idaho Falls, ID 83415-3875

91. Eric Marsh, Earthline Technologies, P.O. Box 579, Ashtabula, OH 44005-0579

92-101. Doug Maynor, U.S. Department of Energy, Ohio Field Office, P.O. Box 3020, Miamisburg, OH 45343-3020

102. Greg McBrien, U.S. Department of Energy, EM-22, Cloverleaf Building, 19901 Germantown Road, Germantown, MD 20874

103. Steve McCracken, U.S. Department of Energy, Fernald Environmental Management Project, P.O. Box 538704, Cincinnati, OH 45253-8704

104. Herman Moore, U. S. Department of Energy, West Valley Development Project, 10282 Rock Springs Road, West Valley, NY 14171-4985

105. Kathi Nickel, U.S. Department of Energy, Fernald Environmental Management Project and Fluor Fernald, Inc., P.O. Box 538704, Cincinnati, OH 45253-8704

106. Bill Owca, U.S. Department of Energy, Idaho National Engineering and Environmental Laboratory, Mixed Waste Focus Area, P.O. Box 1625, Idaho Falls, ID 83415-3875

107. Paul Pettit, Fluor Fernald, Inc., P.O. Box 538704, Cincinnati, OH 45253-8704

108. Chuck Pietsch, BWXTO, P.O. Box 3030, Miamisburg, OH 45343-3020

109. Rick Provencher, U.S. Department of Energy, Miamisburg Environmental Management Project, P.O. Box 3020, Miamisburg, OH 45343-3020

110. Melda Rafferty, U.S. Department of Energy, Portsmouth Office, P.O. Box 700, Piketon, $\mathrm{OH} 45661$

111. Mike Rivera, LATA, Rocky Flats Environmental Technology Site, 1536 Cole Blvd., Bldg. 4, Suite 150, Golden, CO 80401

112. Sherri Robinson, U.S. Department of Energy, Savannah River Site Office, Road 1, Bldg. 703-A, Aiken, SC 29802 
113. Robert Rothman, U.S. Department of Energy, Miamisburg Environmental Management Project, P.O. Box 3020, Miamisburg, OH 45343-3020

114. John Sattler, U.S. Department of Energy, Fernald Environmental Management Project, P.O. Box 538705, Cincinnati, OH 45253-8705

115. Steve Schmucker, Battelle, 505 Kind Ave., Columbus, OH 43201-2693

116. Malcolm Siegel, Sandia National Laboratory, Mail Stop 0755, Albuquerque, NM 87185-0755

117. Frank Tarentello, West Valley Nuclear Services Co., West Valley Development Project, 10282 Rock Springs Road, West Valley, NY 14171-9799

118. Jeffrey Walker, U.S. Department of Energy, EM-54, Cloverleaf Building, 19901 Germantown Road, Germantown, MD 20874

119. Mike West, Los Alamos National Laboratory Environmental Management, Rocky Flats Environmental Technology Site, 10808 Highway 93, Unite B, Bldg. T-130 A, Golden, CO 80403-8200

120-122. Beverly Whitehead, U.S. Department of Energy, EH-413, GA-076, 1000 Independence Ave. SW, Washington, DC 20585

123. Dan Wilken, U.S. Department of Energy, Oak Ridge Operations Office, Federal Building, 200 Administration Road, Oak Ridge, TN 37831

124. Alice Williams, U.S. Department of Energy, West Valley Development Project, 10282 Rock Springs Road, West Valley, NY 14171-4985

125. Tom Williams, U.S. Department of Energy, Ashtabula Environmental Management Project, 1800 East 21st Street, P.O. Box 579, Ashtabula, OH 44044

126. Jennifer Williamson, Earthline Technologies, P.O. Box 579, Ashtabula, OH 44005-0579

127. Jim Wright, U.S. Department of Energy,-Savannah River, Sub Con Focus Area, Savannah River Site Office, Road 1, Bldg. 703-A, Aiken, SC 29802 